Food and Agriculture
Organization of the
United Nations

\title{
Prospects for quinoa adaptation and utilization in Eastern and Southern Africa
}

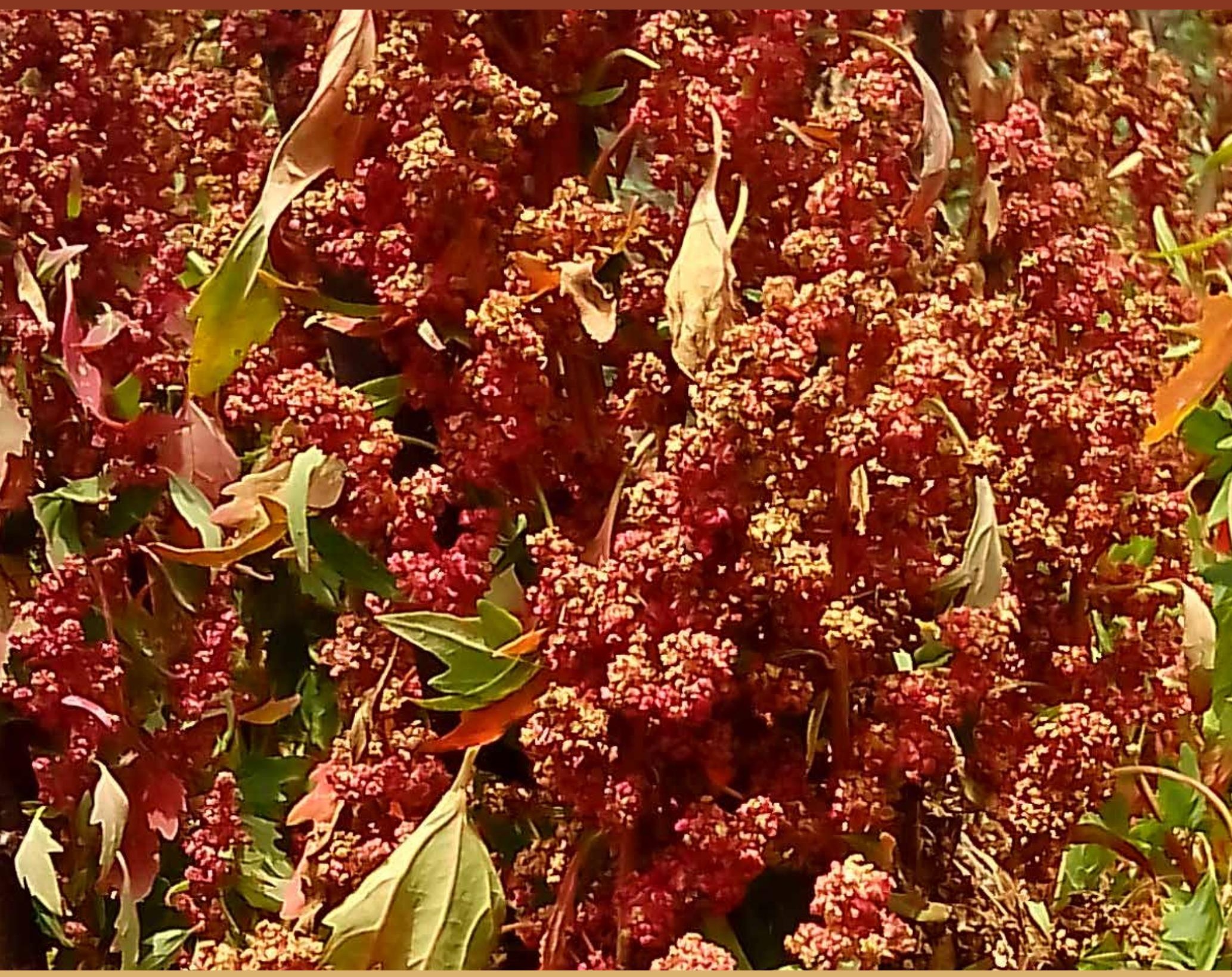

Technological, institutional and policy considerations 



\section{Prospects for quinoa adaptation and utilization in Eastern and Southern Africa}

\section{Technological, institutional and policy considerations}

Prepared by

Moses F.A. Maliro, Crop and Soil Sciences Department, Faculty of Agriculture, Lilongwe University of Agriculture and Natural Resources, Malawi

Mathew Abang, FAO Subregional Office for Eastern Africa, Addis Ababa, Ethiopia

Current address: FAO Subregional Office for Southern Africa, Harare, Zimbabwe

Clare Mukankusi, International Center for Tropical Agriculture, Kawanda, Uganda

Mercy Lung'aho, International Center for Tropical Agriculture, Nairobi, Kenya

Berhanu Fenta, Melkassa Agricultural Research Center, Ethiopian Institute of Agriculture, Adama, Ethiopia

Susan Wanderi, Kenya Agricultural and Livestock Research Organization, Kenya

Regina Kapa, Ministry of Agriculture, Forestry, Tourism, Animal Resources, Fisheries, Cooperatives and Rural Development, Juba, South Sudan

Otim Alfred Okiro, Horticulture Research Programme, National Crops Resources Research Institute, Namulonge, Kampala, Uganda

Eric Kooma and Christopher Mwaba, Zambia Agricultural Research Institute, Mount Makuru Research Station, Chilanga, Zambia

Mohamud Mohamed Isse, Ministry of Agriculture, Somalia

Didier Bazile, CIRAD, Montpellier, France 
Required citation:

Maliro, M.F.A., Abang, M.M., Mukankusi, C., Lung'aho, M., Fenta, B., Wanderi, S., Kapa, R., Okiro, O.A., Koma, E., Mwaba, C., Isse, M.M. and Bazile, D. 2021. Prospects for quinoa adaptation and utilization in Eastern and Southern Africa: Technological, institutional and policy considerations. Addis Ababa, FAO. https://doi. org/10.4060/cb2351en

The designations employed and the presentation of material in this information product do not imply the expression of any opinion whatsoever on the part of the Food and Agriculture Organization of the United Nations (FAO) concerning the legal or development status of any country, territory, city or area or of its authorities, or concerning the delimitation of its frontiers or boundaries. Dashed lines on maps represent approximate border lines for which there may not yet be full agreement. The mention of specific companies or products of manufacturers, whether or not these have been patented, does not imply that these have been endorsed or recommended by FAO in preference to others of a similar nature that are not mentioned.

The views expressed in this information product are those of the author(s) and do not necessarily reflect the views or policies of FAO.

ISBN 978-92-5-133687-8

(C) FAO, 2021

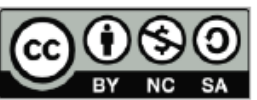

Some rights reserved. This work is made available under the Creative Commons Attribution-NonCommercialShareAlike 3.0 IGO licence (CC BY-NC-SA 3.0 IGO; https://creativecommons.org/licenses/by-nc-sa/3.0/igo/legalcode).

Under the terms of this licence, this work may be copied, redistributed and adapted for non-commercial purposes, provided that the work is appropriately cited. In any use of this work, there should be no suggestion that FAO endorses any specific organization, products or services. The use of the FAO logo is not permitted. If the work is adapted, then it must be licensed under the same or equivalent Creative Commons licence. If a translation of this work is created, it must include the following disclaimer along with the required citation: "This translation was not created by the Food and Agriculture Organization of the United Nations (FAO). FAO is not responsible for the content or accuracy of this translation. The original [Language] edition shall be the authoritative edition."

Disputes arising under the licence that cannot be settled amicably will be resolved by mediation and arbitration as described in Article 8 of the licence except as otherwise provided herein. The applicable mediation rules will be the mediation rules of the World Intellectual Property Organization http://www.wipo.int/amc/en/mediation/ rules and any arbitration will be conducted in accordance with the Arbitration Rules of the United Nations Commission on International Trade Law (UNCITRAL).

Third-party materials. Users wishing to reuse material from this work that is attributed to a third party, such as tables, figures or images, are responsible for determining whether permission is needed for that reuse and for obtaining permission from the copyright holder. The risk of claims resulting from infringement of any thirdparty-owned component in the work rests solely with the user.

Sales, rights and licensing. FAO information products are available on the FAO website (www.fao.org/publications) and can be purchased through publications-sales@fao.org. Requests for commercial use should be submitted via: www.fao.org/contact-us/licence-request. Queries regarding rights and licensing should be submitted to: copyright@fao.org. 


\section{Contents}

Foreword $\quad$ vii

$\begin{array}{ll}\text { Abbreviations and acronyms } & \text { ix }\end{array}$

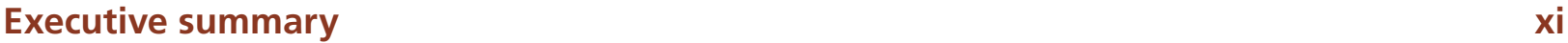

1. Introduction 1

1.1 Quinoa's potential for food security in Africa 1

1.2 Diversification of export crops 1

2. Background 3

3. Country-specific initiatives on quinoa (adaptability studies) 5

3.1 Kenya 6

3.2 Malawi 8

$\begin{array}{lll}\text { 3.2.1 Agronomic studies } & 8\end{array}$

$\begin{array}{ll}\text { 3.2.2 Variety release for use by farmers } & 14\end{array}$

3.2.3 Quinoa in nutritional programmes of rural communities 14

$\begin{array}{ll}3.3 \text { Ethiopia } & 14\end{array}$

3.3.1 First introduction and evaluation trials of quinoa in Ethiopia 14

3.3.2 Promising plant growth and yield results 16

3.3.3 Collaborative research with non-governmental organizations 17

4. FAO subregional approach to introduce quinoa to Africa 19

4.1 Evaluation and experimentation $\quad 19$

4.1.1 Countries and objectives 19

4.1.2 Preparation for pilot trials 19

4.1.3 Implementing institutions in participating countries 20

$\begin{array}{lll}\text { 4.1.4 Evaluation trials - materials and methods } & 20\end{array}$

4.2 Agronomic performance of quinoa in the 14 environments $\quad 24$

4.2.1 Germination and crop establishment 24

4.2.2 Flowering, maturity, panicle length and plant height 25

4.2.3 Panicle length and plant height 26

4.2.4 Grain yield performance $\quad 27$

4.2.5 Genotype by environment ( $\mathrm{G} \times \mathrm{E}$ ) interaction 28

4.2.6 Pests and diseases that affected quinoa in the trials 31

4.3 Nutrient content in quinoa grown in different environments 31

4.4 Quinoa awareness and promotion 32

5. Institutional considerations

5.1 Acquisition of quinoa germplasm 35

5.2 Institutional mandate and quinoa research $\quad 35$

5.3 Institutional capacity building to conduct quinoa research 36 
5.4 Universities - academic research 36

5.5 Non-governmental organizations 36

$\begin{array}{ll}\text { 6. Policy considerations } & 37\end{array}$

7. Lessons from the successes and challenges 39

$\begin{array}{lll}7.1 & \text { Successes } & 39\end{array}$

7.1.1 Awareness among public and non-governmental institutions 39

$\begin{array}{lll}\text { 7.1.2 Plant growth and yield } & 39\end{array}$

$\begin{array}{lll}\text { 7.1.3 National quinoa research capacity } & 39\end{array}$

$\begin{array}{ll}\text { 7.1.4 Quinoa research network } & 39\end{array}$

$\begin{array}{ll}7.2 \text { Challenges } & 40\end{array}$

7.2.1 Acquisition of quinoa germplasm from the Andean countries 40

$\begin{array}{lll}7.2 .2 & \text { Poor seed quality } & 40\end{array}$

7.2.3 Lack of experience in quinoa crop management 40

$\begin{array}{ll}\text { 7.2.4 Unfavourable climatic conditions } & 41\end{array}$

$\begin{array}{lll}\text { 7.2.5 Postharvest processing and handling } & 41\end{array}$

7.2.6 Limited human and laboratory capacity 41

$\begin{array}{ll}\text { 8. Conclusions } & 43\end{array}$

$\begin{array}{ll}\text { 9. Recommendations } & 45\end{array}$

$\begin{array}{ll}\text { 10. Acknowledgements } & 47\end{array}$

$\begin{array}{lr}\text { References } & 49\end{array}$ 


\section{Figures \& Tables}

\section{Figures}

Figure 1: Map of Africa

Figure 2: Map of Kenya showing agro-ecological zones and locations where early quinoa trials were conducted

Figure 3: Map showing quinoa's adaptability experimental sites in Malawi during the 2014-2016 experimental periods

Figure 4: Grain yield ( $\mathrm{kg} / \mathrm{ha}$ ) of quinoa genotypes evaluated at six different sites in Central Malawi during the 2014 irrigated season (May to August 2014) (Fprob. $=0.002$ for genotype, $<0.001$ for sites)

Figure 5: Grain yield ( $\mathrm{kg} / \mathrm{ha}$ ) of quinoa genotypes evaluated at six different sites in Central Malawi during the 2015 irrigated season (May to August 2015) (Fprob. $=<0.089$ for genotype, $<0.001$ for sites, $<0.967$ for genotype $x$ site interaction; SED = 242; $\mathrm{LSD}=477.5$ )

Figure 6: Map of Ethiopia showing locations where early quinoa trials were conducted (2003 to 2005) by EIAR 


\section{Tables}

Table 1: Quinoa genotypes used in the 1999-2000 trial in Kenya (Oyoo et al., 2010)

Table 2: List of quinoa genotypes introduced and evaluated for adaptability in six different environments of central Malawi

Table 3: Description of locations/environments where multilocational evaluation trials of quinoa were conducted in Malawi (2014 and 2015) (See Figure 3 for location of the sites)

Table 4: List of quinoa genotypes (and institutions that provided the germplasm) that were introduced (in 2000) and evaluated for adaptability in different environments of Ethiopia

Table 5: Average performance in duration to flowering (days) and maturity (days) and grain yield $(\mathrm{kg} / \mathrm{ha}$ ) of two of the surviving quinoa genotypes evaluated in four locations of Ethiopia from 2003 to 2005 under rainfed conditions (Amsalu, 2014)

Table 6: List and characteristics of 23 experimental sites in Eastern Africa where quinoa adaptability studies were conducted in 2015

Table 7: List of quinoa genotypes and genotypes supplied for the studies (FAO facilitated the exchange of germplasm from Peru with Standard Material Transfer Agreement signed)

Table 8: Soil characteristics of some of the experimental sites

Table 9: Seed quality test results for quinoa genotypes sampled from Somalia batches received from Peru (KEPHIS laboratory)

Table 10: Variation in days from sowing to flowering (DSF) and days to physiological maturity (DPM) among 10 quinoa varieties in fourteen sites of Eastern and Southern African countries (s.d. = standard deviation, s.e.m. = standard error of mean)

Table 11: Variation in panicle length $(\mathrm{cm})$ and plant height $(\mathrm{cm})$ in 10 quinoa genotypes in fourteen sites of Eastern and Southern African countries (s.d. = standard deviation, s.e.m. = standard error of mean)

Table 12: Variation in yield ( $\mathrm{kg} / \mathrm{ha}$ ) in 10 quinoa genotypes (listed in Table 9) in fourteen sites of Eastern and Southern African countries (s.d. = standard deviation, s.e.m. = standard error of mean)

Table 13: Finlay Wilkinson analysis of variance for parameters of 11 quinoa genotypes among 14 environments

Table 14: Additive main effects and multiplicative interaction (AMMI) model for 10 quinoa genotypes evaluated in 11 environments

Table 15: Stability coefficients for genotype by environment data (AMMI)

Table 16: Cultivar superiority for test genotypes across 14 environments

Table 17. The protein content (\%) and amino acid profile $(\mu \mathrm{g} / \mathrm{g})$ of quinoa seeds grown in different research sites in Uganda (Mbarara and Namulonge) and Zambia (Mount Makulu) (Lughano et al., 2017 (in review)) 


\section{Foreword}

Protein-energy malnutrition (PEM) remains a public health concern in most developing nations. A number of policy frameworks stress the urgent need to increase public and private investments in agriculture and boost production and productivity while making diets more nutritious and food systems more resilient. For instance, FAO's vision is that of “a world free from hunger and malnutrition, where food and agriculture contribute to improving the living standards of all, especially the poorest, in an economically, socially and environmentally sustainable manner". This ambitious agenda is aligned with the Sustainable Development Goals (SDGs) as well as the commitment African Heads of State and Government made at Malabo, Equatorial Guinea (Malabo Declaration) to transform the continent's agriculture and food systems as captured in the Comprehensive Africa Agriculture Development Programme (CAADP).

The UN General Assembly declared 2013 as the 'International Year of Quinoa' with the aim of raising awareness of how this grain crop can provide nutrition, increase food security and help eradicate poverty around the world. Quinoa can be cultivated from sea level up to 4000 metres above sea level and from arid regions to wet environments. Quinoa grain is consumed as a cereal, with its protein containing a well-balanced complement of all essential amino acids, a property that makes it superior to grains of other food crop species such as wheat, barley and soybean. The grain is also rich in mineral nutrient content of calcium, iron, magnesium, potassium, phosphorus, zinc and manganese. As quinoa is gluten-free, it can be safely eaten by those with gluten allergies.

With many African countries struggling to achieve food and nutrition security, there is the felt need to harness the unique qualities of quinoa to combat malnutrition and cope with abiotic stresses associated with climate change. However, the introduction of quinoa to a new society requires technological, institutional and policy considerations to facilitate and enable adoption and utilization of the crop. The International Year of Quinoa was in recognition of the indigenous peoples of the Andes, who have traditionally preserved quinoa as a food thanks to their longstanding knowledge and cultivation practices. The protein content of quinoa grain ranges from 12 to 17 percent and is reported to vary with factors such as cultivar, soil fertility and environment. The mineral nutrient content is also expected to vary with soil nutrient status. It is therefore necessary to study crop adaptation, nutrient composition and utilization when quinoa is introduced to new environments. Within the framework of FAO's commemoration of 2013 as the 'International Year of Quinoa', a Technical Cooperation Programme (TCP) project was developed involving six Eastern African countries (Djibouti, Ethiopia, Kenya, Somalia, South Sudan, Uganda) and Zambia to assess the capacity of quinoa to adapt to different agro-ecological regions and the nutritional quality of the resulting grain.

This technical paper begins with an introduction to quinoa and its potential for food security and export diversification in Africa. It explains the background to the TCP project and the country-specific initiatives that took place in Ethiopia, Kenya and Malawi prior to the initiation of the TCP. This is followed by a description of FAO's approach to the introduction and evaluation of quinoa under diverse farming systems and agro-ecological regions in Eastern and Southern Africa. A synthesis of the methodology applied in the adaptability studies is presented as well as the results, successes, challenges and lessons learned. Also, the findings of an evaluation of the protein content and amino acid profile of three genotypes of quinoa grown under different agro-ecological conditions in Ethiopia, Kenya, Uganda and Zambia are presented. Recommendations are made from technological, institutional and policy perspectives regarding what countries can do to advance the introduction, production and utilization of quinoa in Eastern and Southern Africa. 
The development of the technical paper was a highly collaborative effort among technical experts at the FAO Subregional Office for Eastern Africa, the Ministries of Agriculture and agricultural research institutions of the seven project-implementing countries, as well as the International Center for Tropical Agriculture (CIAT) and the French Agricultural Research Centre for International Development (CIRAD). The technical review of the paper was undertaken by the quinoa expert of the Plant Production and Protection Division at FAO Rome.

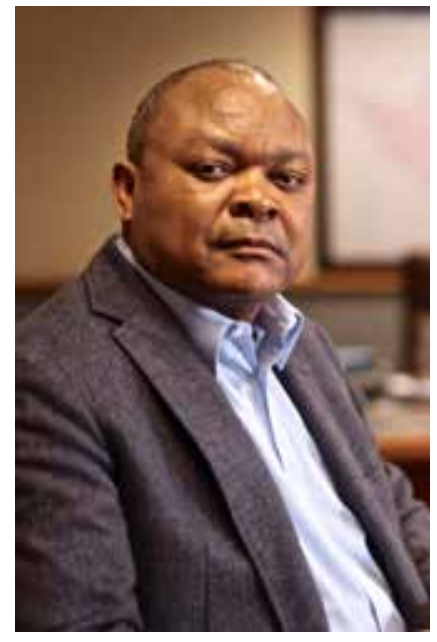

\section{Dr Chimimba David Phiri}

FAO Subregional Coordinator for Eastern Africa \& Representative to the African Union and United Nations Economic Commission for Africa 


\section{Abbreviations and acronyms}

\begin{tabular}{|c|c|}
\hline AMMI & Additive main effect and multiplicative interaction \\
\hline AS & Ammonium sulphate \\
\hline ASALs & Arid and semi-arid lands \\
\hline ATCC & Agricultural Technology Clearing Committee \\
\hline CGIAR & Consultative Group on International Agricultural Research \\
\hline CIAT & International Center for Tropical Agriculture \\
\hline CIP & International Potato Center \\
\hline CIRAD & French Agricultural Research Centre for International Development \\
\hline DANIDA & Danish International Development Agency \\
\hline DCA & DanChurchAid \\
\hline DF & Days to flowering \\
\hline DPM & Duration to physiological maturity \\
\hline DSF & Duration from sowing to flower \\
\hline EIAR & Ethiopian Institute of Agricultural Research \\
\hline EPA & Extension Planning Area \\
\hline FAO & Food and Agriculture Organization of the United Nations \\
\hline FW & Finlay Wilkinson \\
\hline GCN-quinoa & Global Collaborative Network on Quinoa \\
\hline IYQ & International Year of Quinoa \\
\hline KARLO & Kenya Agricultural \& Livestock Research Organization \\
\hline KEPHIS & Kenya Plant Health Inspection Service \\
\hline LUANAR & Lilongwe University of Agriculture and Natural Resources \\
\hline MACC II & Management for Adaptation to Climate Change II \\
\hline MAAIF & Ministry of Agriculture, Animal Industry and Fisheries \\
\hline MoA & Ministry of Agriculture \\
\hline NaCRRI & National Crops Resources Research Institute \\
\hline NARIs & National agricultural research institutes \\
\hline NARL & National Agricultural Research Laboratories \\
\hline NARS & National Agricultural Research System \\
\hline NCST & National Council for Science and Technology \\
\hline NEMA & National Environmental Monitoring Authority \\
\hline NGO & non-governmental organization \\
\hline PABRA & Pan Africa Bean Research Alliance \\
\hline R4D & Research for development \\
\hline RCBD & Randomized complete block design \\
\hline SFE & FAO Subregional Office for Eastern Africa \\
\hline SMTA & Standard Material Transfer Agreement \\
\hline TCP & Technical Cooperation Programme \\
\hline TLC & Total Land Care \\
\hline UN & United Nations \\
\hline WSU & Washington State University \\
\hline YDHA & Yield per hectare \\
\hline ZARI & Zambia Agriculture Research Institute \\
\hline
\end{tabular}




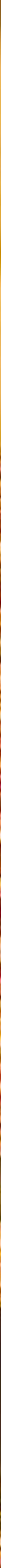




\section{Executive summary}

Quinoa (Chenopodium quinoa Willd.) is an emerging crop around the globe, with great potential to contribute to Africa's food and nutrition security. Its important gain in popularity over the last seven years is attributed to the impact of activities carried out within the framework of the International Year of Quinoa (IYQ2013), which significantly raised awareness of the crop's multiple nutritional benefits and its growing global cultivation.

The Food and Agriculture Organization of the United Nations (FAO) championed the IYQ2013 since the first solicitation of Bolivia. FAO is working with developing countries outside the Andean region that are struggling to meet food and nutrition security goals to introduce and promote the cultivation of quinoa. Production and utilization of quinoa are expected to reduce food and nutrition insecurity in a significant way and help farming communities adapt to climate change impacts. Among the FAO's quinoa-related activities are those of the Technical Cooperation Programme (TCP) project - "Technical assistance for the strengthening of the food system of quinoa" (TCP/SFE/3406) - implemented in the period 2014 to 2015. This project was designed to support the institutional capacities of seven countries (Djibouti, Ethiopia, Kenya, Somalia, South Sudan, Uganda and Zambia) in the production, evaluation, management, utilization and marketing of quinoa under diverse farming systems and agro-ecological zones. The project was implemented and led by the FAO Subregional Office for Eastern Africa (SFE). Quinoa evaluation trials conducted across multiple sites in the participating countries served as pilot adaptability studies for the crop in Eastern Africa and Zambia. The project also drew experience from quinoa introductions and adaptability studies previously conducted through bilateral collaborative projects in Ethiopia, Kenya and Malawi. A synthesis of the results showed that the following technological, institutional and policy considerations need to be made to facilitate the introduction and adoption of quinoa in farming communities of different agro-ecological areas in Africa:

1) Varieties (or genotypes) evaluated vary in their plant-growth and grain-yield performance across different environments in the region. Therefore, for quinoa production to be possible across different ecological zones, varieties adapted to specific ecological regions or zones need to be selected locally and for local farming systems. Quinoa yields as high as or even higher (one to five tonnes per hectare) than those realized in traditional production areas of quinoa are possible. There are also some genotypes whose protein content and quality (balance of amino acids) vary with soil nutrient status across environments.

There is a need for further testing of the varieties in the seven countries as data generated so far are from a single season with the exception of Malawi (where seven varieties were released in 2017 for use by farmers) and Ethiopia (where quinoa genotypes have been evaluated for more than one season and one variety has been released). Several gaps in seed quality, pathology, physiology, agronomy and genetics remain for the researchers to understand quinoa as a potential crop for introduction into the African food systems. Expertise needs to be engaged to address all these research gaps as multilocational trials are extended to include more agro-ecological zones. There is a need for capacity building of both scientists and technicians in quinoa crop research, which can either take the form of short training courses or visits to countries more experienced in quinoa research in the region or to the Andean countries. Support for undergraduate and postgraduate research on quinoa crop agronomy and utilization needs to be included to promote sustainability of the quinoa 'revolution' in Africa.

2) Low seed viability constrained plant establishment in all sites of the evaluation trials under the FAO-TCP project. Seed quality will therefore be a key factor for successful adaptation trials of quinoa as well as for promotion of the crop. 
A seed system for quinoa needs to be developed (certification and standards) focusing on seed multiplication and maintenance of varieties to support the efforts of quinoa introduction and promotion. The seed system also needs to be aligned with national selection and plant breeding requirements for the development of local varieties.

3) The adaptation trials that have been conducted in the past, such as those in Ethiopia, Kenya and Malawi as well as the FAO-TCP project, have created a 'start up' capacity to drive the introduction and promotion of quinoa on the African continent. The researchers who were engaged in the trials represent the human capacity that has been built - they are now knowledgeable and have gained basic experience in quinoa growing.

The consortium that was created in quinoa research needs to take advantage of the experience acquired and momentum gained to develop a regional quinoa project that will help countries accelerate the commercialization of quinoa, which may be slow with individual country efforts.

4) National agricultural research institutes (NARIs) that conducted the quinoa evaluation trials have a network of research infrastructure across agro-ecological zones in most of the countries, making them well-positioned for the introduction, testing and promotion of quinoa. Agricultural universities played an important role to introduce quinoa and conduct adaptability and on-farm studies. Certain non-governmental organizations that are working with farming communities as well as with women on nutritional programmes have emerged as effective partners in the promotion of quinoa production and its utilization, as in the case of Total Land Care (TLC) and the Lilongwe University of Agriculture and Natural Resources (LUANAR) in Malawi. Such partnerships facilitated on-farm trials of introduced quinoa varieties conducted across different agro-ecological zones, leading to approval by the Agricultural Technology Clearing Committee (ATCC) and the release of seven varieties in Malawi in August 2017.

Where possible, the current NARIs should continue leading quinoa research and promotion in their countries and capitalizing on the existing network with international research institutions, non-governmental organizations (NGOs) and farmer organizations as well as with the private sector to promote production and utilization of quinoa. A multi-disciplinary and multiinstitutional team of researchers is likely to accelerate adoption of the new crop. The Consultative Group on International Agricultural Research (CGIAR), in this case the International Center for Tropical Agriculture (CIAT), was fundamental in supporting FAO in coordinating the regional project based on its successful track record in coordinating research partnerships, a good example being the Pan Africa Bean Research Alliance (PABRA) that comprises 31 NARIs and over 350 other partners that contribute to different components of the common bean value chain.

5) Awareness creation initiated among technocrats, policy-makers and the public needs to continue to promote quinoa as a healthy food crop with high potential to contribute to food and nutrition security in the countries that participated in the project.

Cross-cutting issues such as gender and HIV/AIDS need to be included in project activities promoting quinoa utilization. In many African societies, food insecurity is generally localized in social groups and aggravated by gender inequalities that disadvantage specific sections of the population such as women and children. 
6) A regional approach of introducing quinoa crop (thus acquisition of germplasm from Peru through the FAO regional office, characterization of testing sites, experimental design and analyses and nutrient analysis of seed samples grown from the testing sites) was effective as it provided a platform for sharing information and experience that would not otherwise have been possible. Individual countries had to adapt their season of planting/sowing according to the rainy season as this varied from country to country.

The regional quinoa research network championed by FAO needs to continue to serve as a platform for the exchange of information and discussion among various stakeholders in the region.

7) Engagement of stakeholder institutions in the early stages of introducing quinoa crop increased awareness in most of the participating countries in Eastern Africa and Malawi. Farmers in Malawi appreciated the importance of quinoa grain and explored the use of the leaves as a vegetable.

8) In many countries, agricultural research and production policies emphasize or are biased towards a few major cereal and legume crops (such as maize and common bean) for food security, while many indigenous food crops (neglected and underutilized species) that have played an important nutritional security role in the farming households in past centuries have been neglected by research and extension. Introduction of quinoa at national levels should be done in full recognition of its unique nutritional contribution, thus ensuring that it doesn't suffer the same fate as the neglected and underutilized crop species.

National agricultural research and production policies need to envisage funding for promotion of emerging crops like quinoa to meet specific domestic and export market needs.

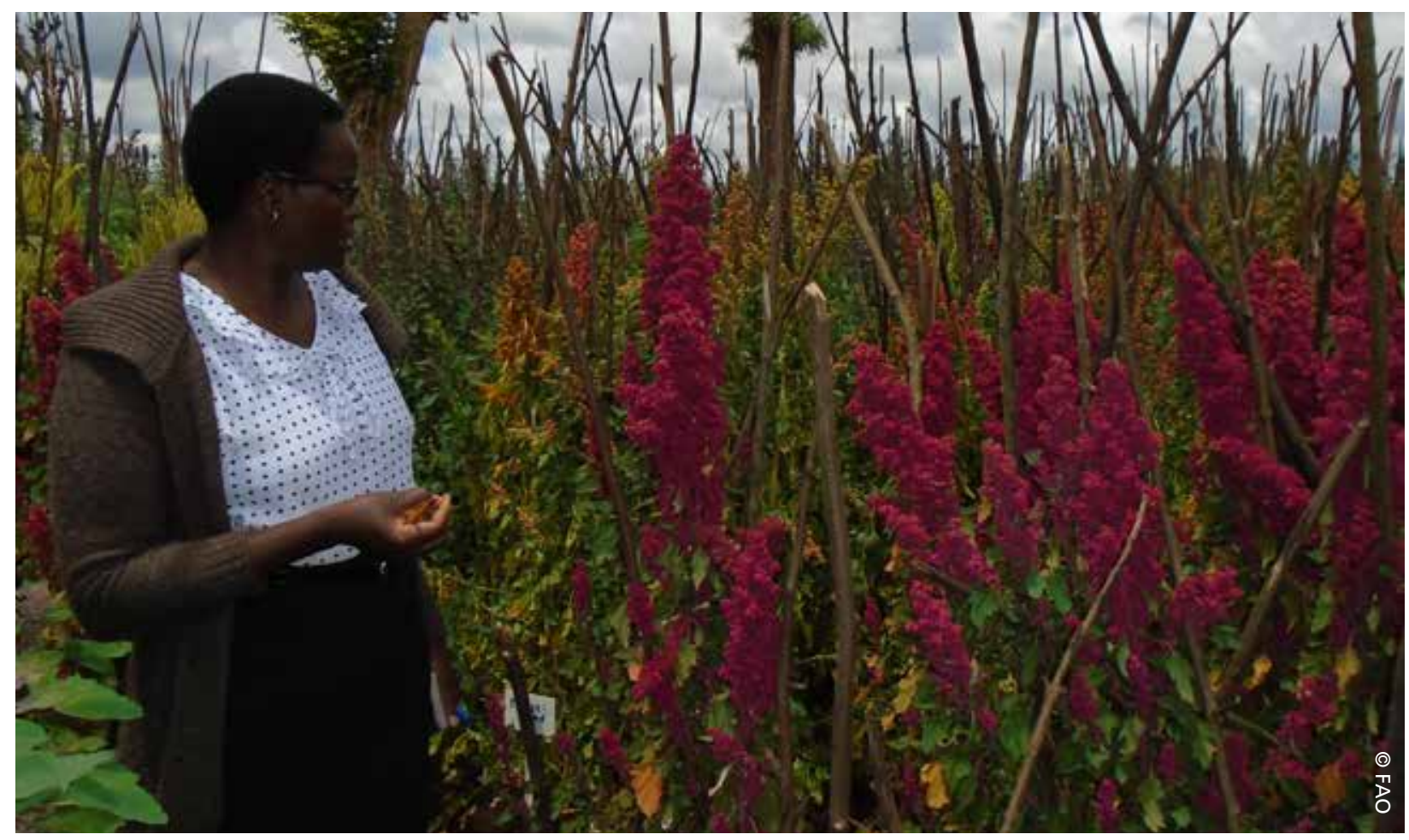



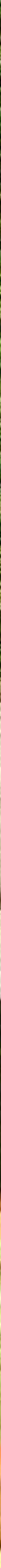

(5), 1 archenges

(

entas

s.

1

S

(3)

a)

(1).

(

4

- 1

.

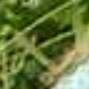




\section{Introduction}

\subsection{Quinoa's potential for food security in Africa}

Quinoa (Chenopodium quinoa Willd.) is an emerging crop around the globe, with great potential to contribute to Africa's food and nutrition security (Ruiz et al., 2014). Quinoa grain has been a source of nourishment for people of the Andean region in South America for about 7000 years since its domestication (Pearsall, 1992). Selection and maintenance of quinoa cultivars over the millennia by generations of farmers in the region has led to the development of cultivars adapted to diverse environments of the Andean region. These farmers contributed to the high genetic diversity of the crop that enables the selection of new quinoa genotypes for introduction and adaptation to other environments. Today there is a high probability of selecting better-performing quinoa genotypes for introduction to most environments around the globe.

Quinoa survived the neglect that came with the Spanish conquest and introduction of 'Old World' food crop species in the Andean region until the second half of the 20th century, when the nutritional status of quinoa was rediscovered, leading to a renaissance in its production (Bazile and Baudron, 2015; Repo-Carrasco et al., 2003). Since the rediscovery, research into the possibility of producing quinoa across the globe has increased exponentially (Bazile et al., 2016).

With many of the African countries struggling to achieve their food and nutrition security goals, the possibility of introducing quinoa as a food crop on the continent has been considered to cope with abiotic stresses associated with climate change impacts and to combat malnutrition. Quinoa can be cultivated from sea level up to 4000 metres above sea level and from arid regions to wet environments (Delatorre-Herrera and Pinto, 2009; Fuentes et al., 2012; Orsini et al., 2011; Ruiz-Carrasco et al., 2011; Pulvento et al., 2012).

Quinoa grain is consumed as a cereal, with its protein containing a well-balanced complement of all essential amino acids, a property that makes it superior to grains of other food crop species such as wheat, barley and soybean (Repo-Carrasco et al., 2003; Risi , 1993). The grain is also rich in mineral nutrient content of calcium, iron, magnesium, potassium, phosphorus, zinc and manganese. As quinoa is gluten-free, it can be safely eaten by those with gluten allergies (Zevallos et al., 2015 ). The protein content of quinoa grain ranges from 12 to 17 percent and is reported to vary with factors such as cultivar, soil fertility and environment (Rojas et al., 2015). The mineral nutrient content is also expected to vary with soil nutrient status. It is therefore necessary to study plant growth adaptation, nutrient composition and utilization when quinoa is introduced to new environments.

\subsection{Diversification of export crops}

There is a growing demand for quinoa grain in developed countries (Bazile, Bertero and Nieto, 2015) and among the affluent and the expanding middle class in developing countries (Bazile et al., 2015; Maliro and Guwela, 2015; Jacobsen, 2003). Quinoa, therefore, is a potential crop to add to the diversity of cash crops in the African economies so that it can contribute to improving the socio-economic status of small-scale farmers in the region (Coulibaly et al., 2015). Many developing countries in Africa, like Malawi, have for many years depended on tobacco as a main export crop and forex earner. However, the decline in global demand for tobacco $(F A O, 2003)$ has seen the economies of such countries nearly collapsing, sending them on a quest to diversify their export crop base by promoting the production of legumes and pulses. The global demand for quinoa presents another export opportunity to such countries. 

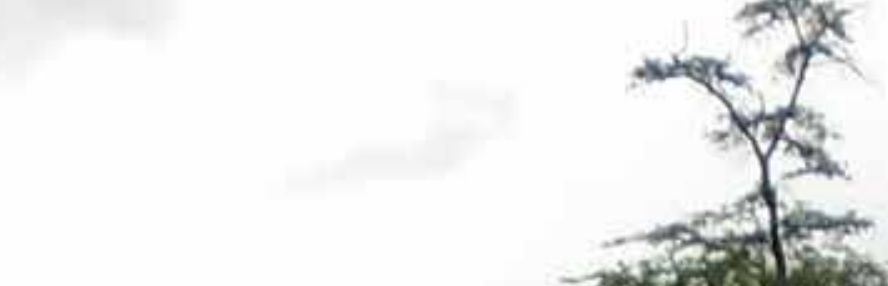
S.

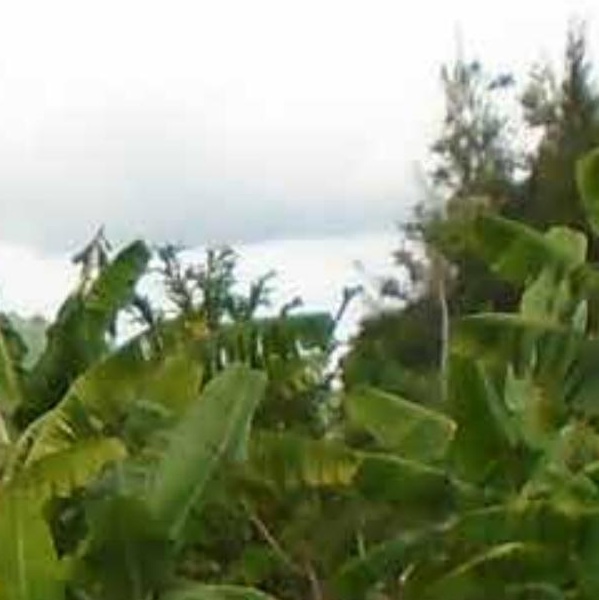

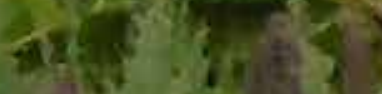

in.

Wh $(1)$

2.75 s. - रंजाय

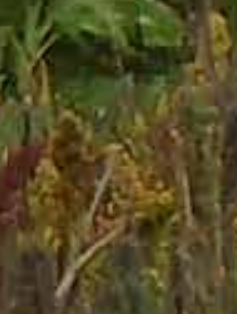

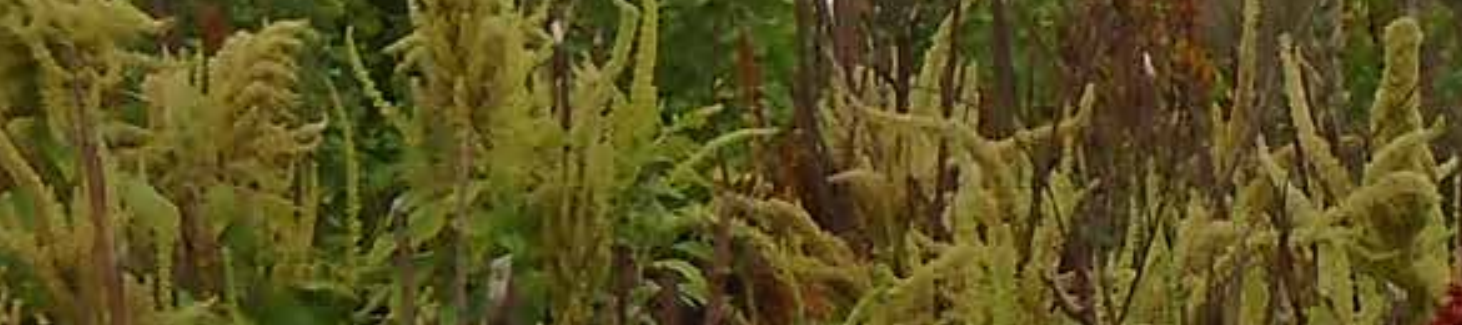

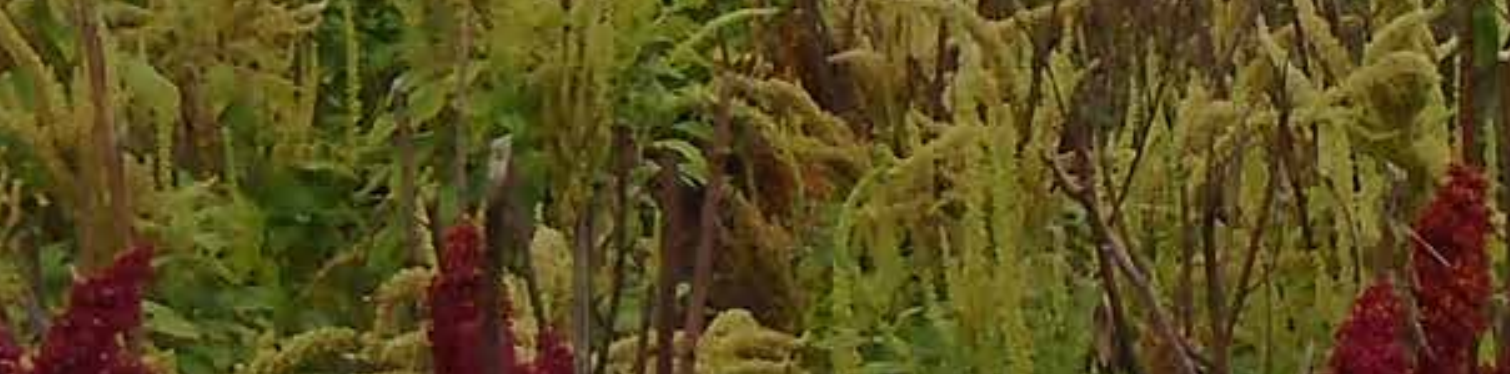

ind

Int

fit

(i) $1 \times 1$ :

\$

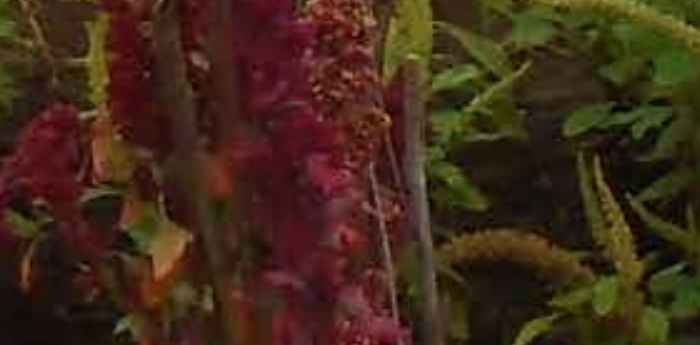

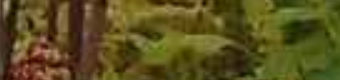

$207=92$

(3)
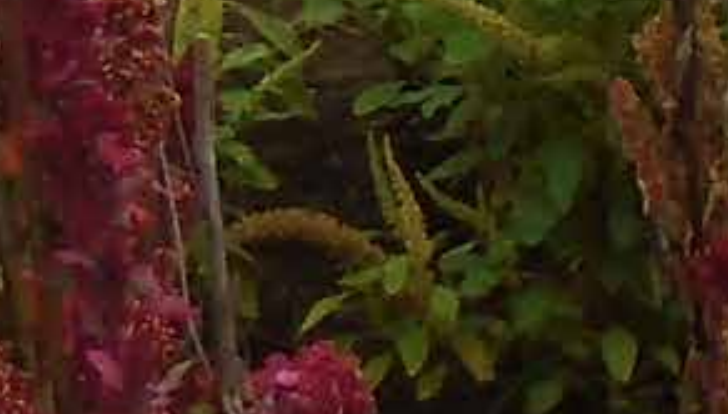

1. 25

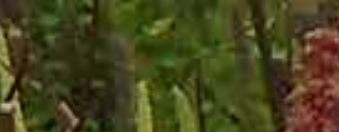

Q.

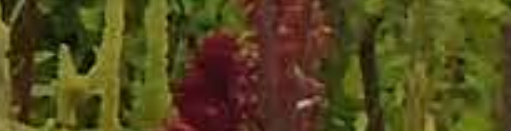

is:

$\cos \left(2+60^{2}\right)$

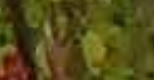

fif: $\frac{3}{3}$

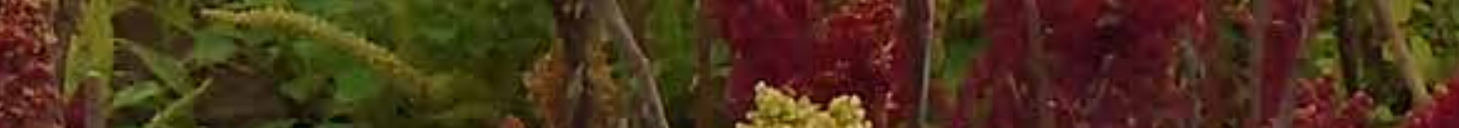

$-5(1)$

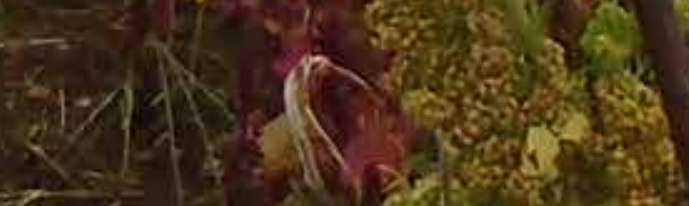




\section{Background}

The introduction of quinoa to a new society requires technological, institutional and policy considerations that enable and facilitate acceptance and utilization of the crop. While quinoa is known to have a wide climatic adaptation and superior nutrient composition, this does not guarantee successful production and utilization. The eastern and southern Africa region has a high climatic and geographic diversity ranging from dry to wet and warm to cool ecological zones, low to high altitude and with varied soil types and soil fertility.

Institutional structures and linkages vary from country to country and are at different stages due to variation in governance and political stability, such that delivery of agricultural technologies to the farming communities also face different challenges. Policies on agriculture are at different levels of development among the countries in East and Southern Africa. These variations were revealed in findings from early adaptability studies of quinoa. This paper synthesizes the methodologies applied in the adaptability pilot experiments, results, successes, challenges and lessons learned. Recommendations are made about what countries with support from the development partner organizations can do to advance the introduction, production and utilization of quinoa into the food systems of the region.

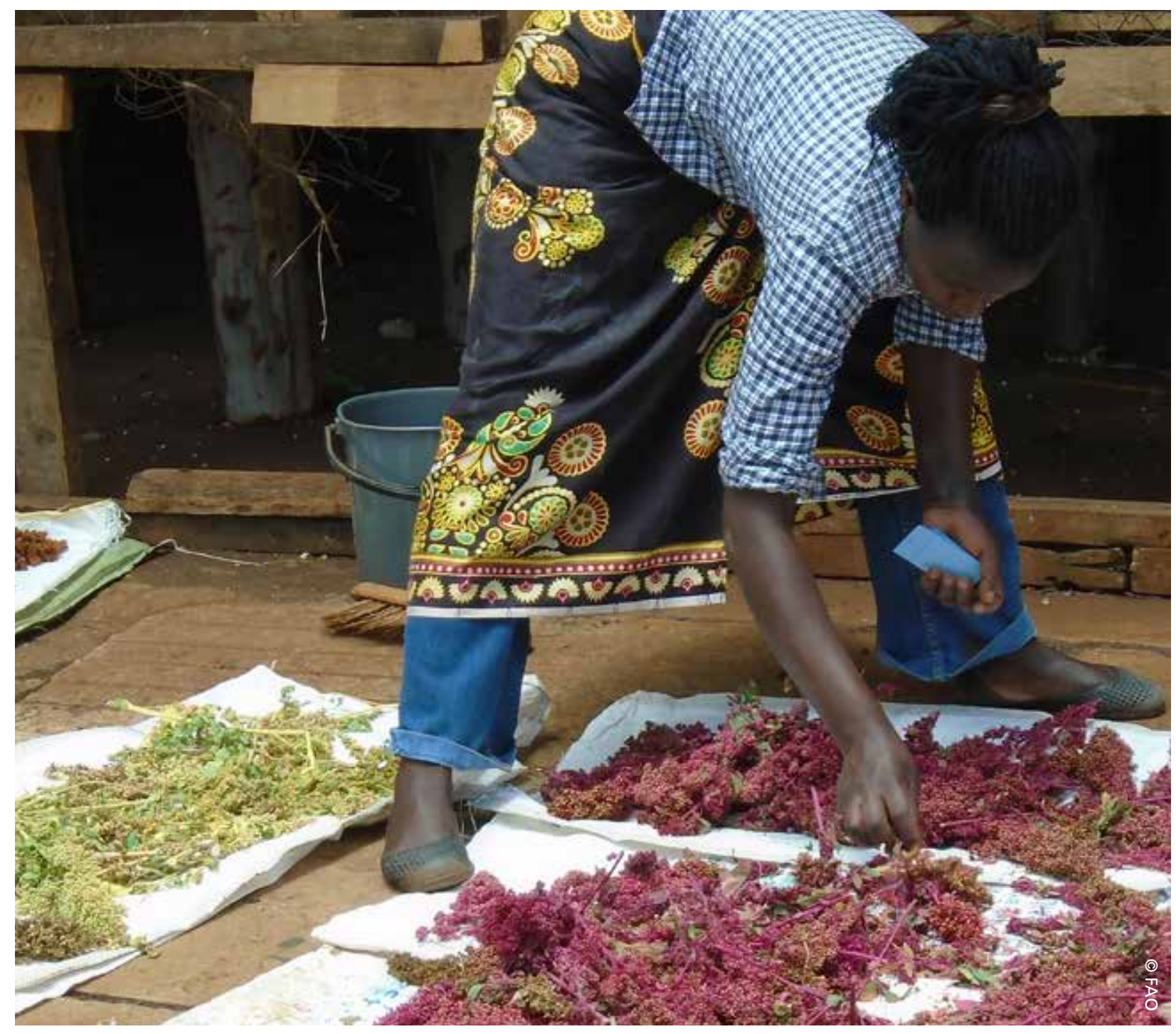





\section{Country-specific initiatives on quinoa (adaptability studies)}

Technological considerations for the introduction of quinoa to East and Southern African countries concentrated on evaluating and selecting germplasm with better agronomic performance in various environments and to some extent on utilization. Early (before 2013) adaptability studies in the subSaharan region were conducted in Ethiopia, Kenya, Malawi and Mali (Jacobsen, 2003; Oyoo et al., 2010; Maliro and Guwela, 2015, Maliro et al., 2017). Later studies (Bazile et al., 2016) were conducted under three TCPs concerning quinoa in Africa - North Africa (in an FAO Regional Office for the Near East and North Africa project), West Africa with Ghana coordination (Ghana and Mali) and East Africa with SFE (in seven countries) through an FAO initiative after 2013 was declared the International Year of Quinoa (IYQ) by FAO and the UN, and FAO was requested to champion technical assistance to countries in sub-Saharan Africa in the introduction of the crop. FAO, through its Subregional Office for Eastern Africa, initiated a TCP project titled 'Technical assistance for the strengthening of the food system of quinoa' (TCP/SFE/3406) to support the institutional capacities of beneficiary countries in the production, evaluation, management, utilization and marketing of quinoa under diverse farming systems and in diversified agro-ecological regions. The participating countries included Djibouti, Ethiopia, Kenya, Somalia, South Sudan, Uganda and Zambia (Figure 1).

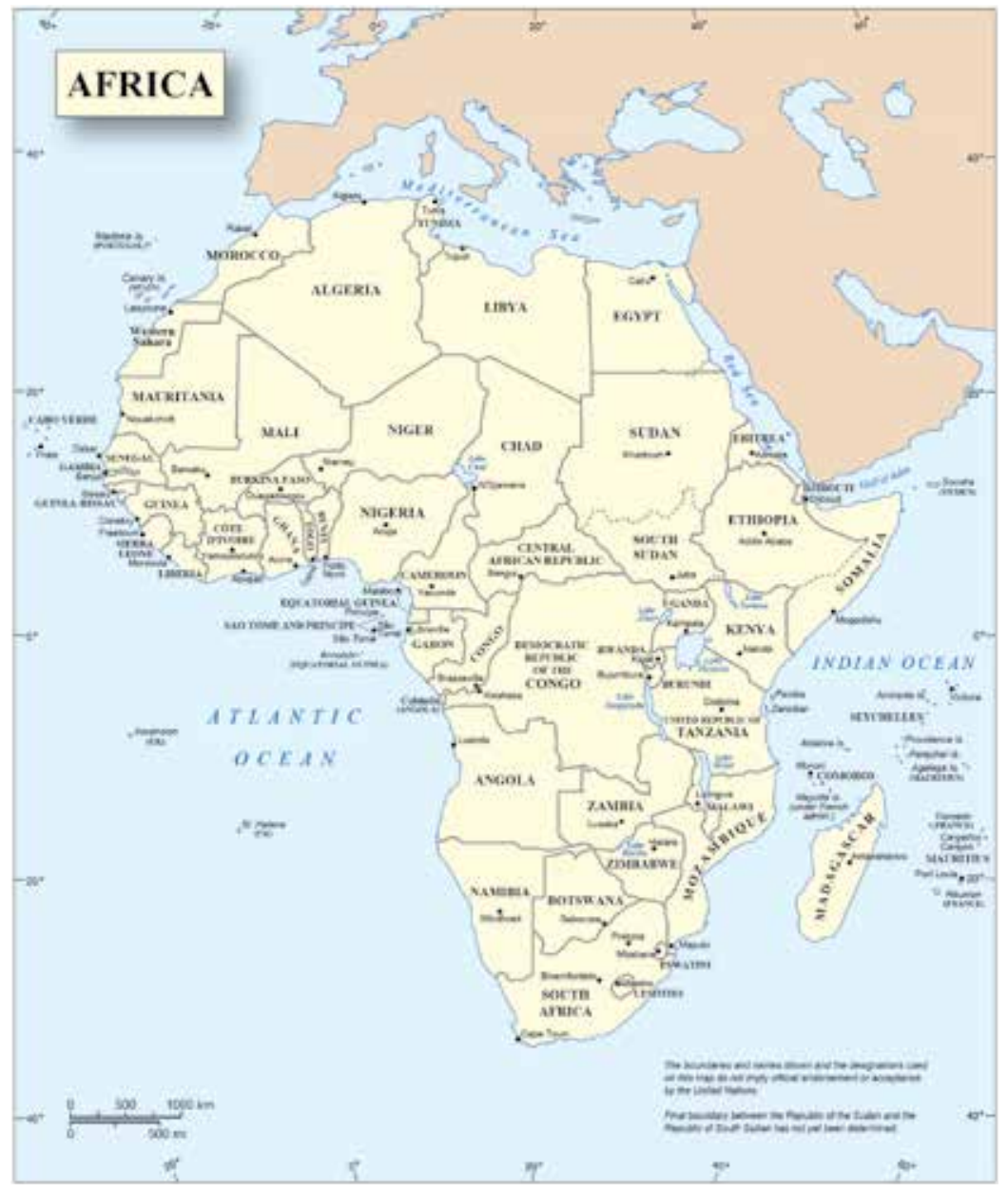

Figure 1: Map of Africa

Source: Elaborated by the authors. Conforms to Map No. 4045 Rev. 8.1 United Nations, 2018.

(Site: https://www.un.org/geospatial/mapsgeo) 


\subsection{Kenya}

Kenya has six ecoclimatic zones that were classified based on climatic, vegetative and soil characteristics. These include Zone I, Afro-Alpine moorland and grassland, found at high altitudes (2 350 m.a.s.l) above the forest line; Zone II, humid to dry subhumid climate; Zone III, dry subhumid to semi-arid climate; Zone IV, semi-arid climate; Zone V, arid climate; and Zone VI, very arid climate (Figure 2 shows the ecozones based on precipitation). Zones IV to VI account for 72 percent of Kenya's total land area and are usually referred to as the arid and semi-arid lands (ASALs) of Kenya (Ojany and Ogendo, 1988). Rainfall in the ASALs is sparse and highly variable and therefore crop production is not assured (Khaemba, 2015). Introduction of quinoa would therefore require acquisition of germplasm materials that are diversely adapted to similar environments.

The crop was not introduced systematically to Kenya, such that detailed follow-up trials have not been possible. Available literature shows that quinoa was first evaluated in Kenya between 1935 and 1939 to test the adaptability of the crop to the local environments. Cream-coloured seeds of quinoa were obtained from the Royal Botanic Gardens and tested in different sites including Kitale (Zone II, at 1828 m.a.s.l), Kapenguria (Zone IV, at 2134 m.a.s.l), Kiambu (Zone II, at 2438 m.a.s.l) and Scott Agricultural Laboratories (Zone II, at 1737 m.a.s.l) (Elmer, 1942) (Figure 2). Results from these studies showed that unlike other cereal crops such as maize, quinoa did not necessarily require fertile soils, hence it grew well in marginal soils. Results showed that the crop was able to grow in areas higher than 1829 m.a.s.l, with rainfall that ranged from 381 to $635 \mathrm{~mm}$ during the growing season, and that the crop matured within 4.5 to 6 months. However, no follow-up studies or record of germplasm conserved from such studies can be traced.

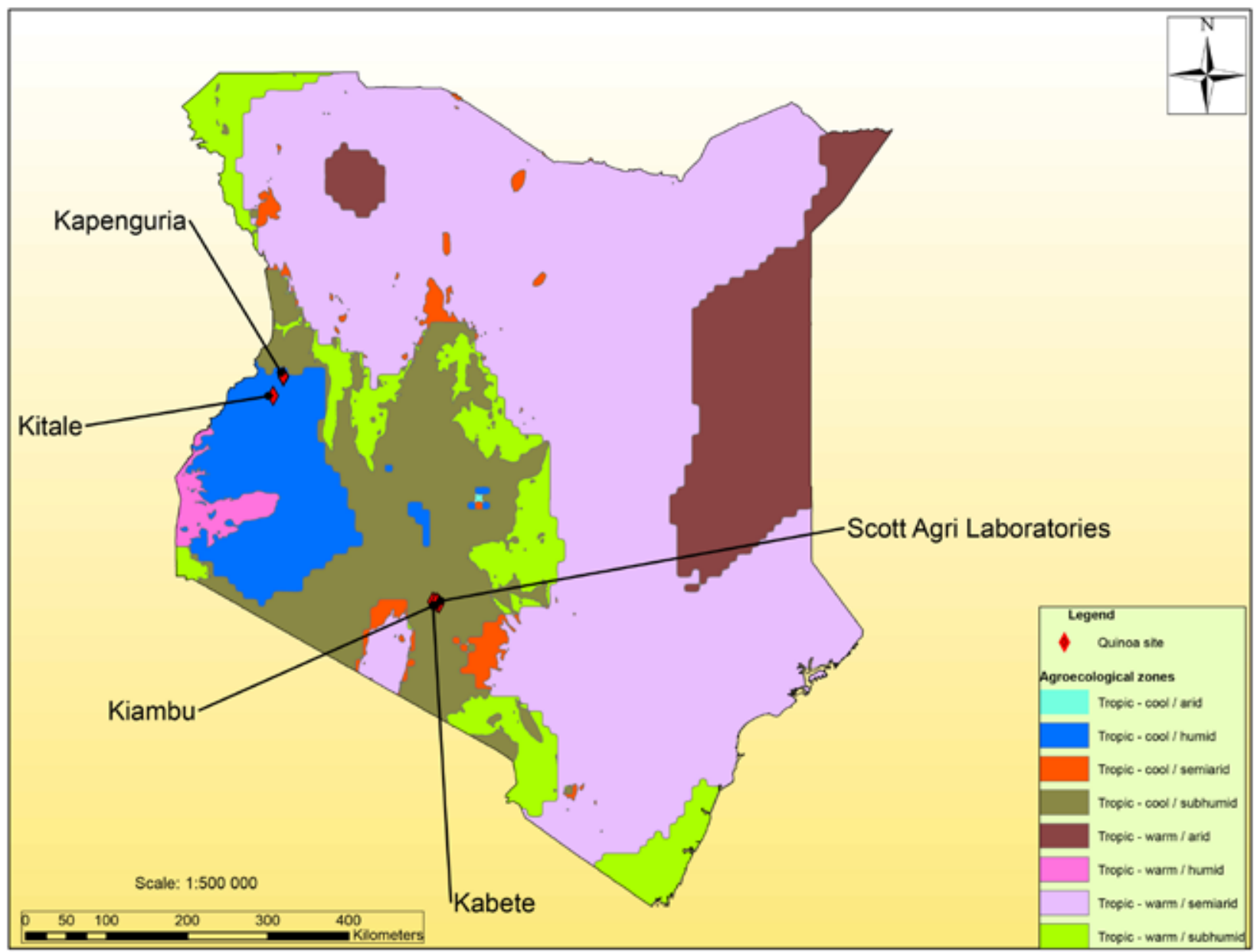

Figure 2: Map of Kenya showing agro-ecological zones and locations where early quinoa trials were conducted.

Adapted from figure 1b of Macharia, M., Ngetich, F.K. and Shisanya, C.A. 2020. Comparison of satellite remote sensing derived precipitation estimates and observed data in Kenya. Agricultural and Forest Meteorology, Volume 284 (2020), 107875. Elsevier B.V., https://doi.org/10.1016/j.agrformet.2019.107875. Accessed from Comparison of satellite remote sensing derived precipitation estimates and observed data in Kenya (ku.ac.ke) 
Table 1: Quinoa genotypes used in the 1999-2000 trial in Kenya (Oyoo et al., 2010)

\begin{tabular}{|l|l|l|}
\hline Country of origin & $\begin{array}{l}\text { Number of genotypes } \\
\text { sourced }\end{array}$ & Names/accession names of genotypes \\
\hline Peru & 8 & $\begin{array}{l}\text { CICA-127, CICA-17, Huariponcho, Kancolla, 03-21-079BB, } \\
\text { 03-21-072RM, IIIpa, Salcedo }\end{array}$ \\
\hline Bolivia & 4 & Ratuqui, Kamiri, Real, Sayana \\
\hline England & 2 & RU-2, RU-5 \\
\hline Holland & 1 & NL-6 \\
\hline Denmark & 2 & E-DK-4, G-205-95 \\
\hline Ecuador & 2 & Ingapirca, ECU-420 \\
\hline Chile & 2 & Canchones, Baer \\
\hline Colombia & 1 & Narino \\
\hline Argentina & 1 & Jujuy \\
\hline Brazil & 1 & Embrapa \\
\hline Total & 24 & \\
\hline
\end{tabular}

The next quinoa study was conducted in 1999-2000 when the performance of 24 quinoa genotypes (Table 1) was assessed (Bertero et al., 2004; Oyoo et al., 2010). The objective was to determine adaptability and yield performance of quinoa under Kenyan conditions and as part of an international multi-environment trial (Bertero et al., 2004). The genotypes were sourced from Argentina, Bolivia, Brazil, Chile, Colombia, Denmark, Ecuador, Peru and the Netherlands through the International Potato Center (CIP) in Nairobi. The studies were conducted at the Kabete Field Station of the University of Nairobi (Figure 2), located at an altitude of 1820 m.a.s.l with a temperature range of $13-23{ }^{\circ} \mathrm{C}$ and an annual rainfall of $970 \mathrm{~mm}$.

These studies provided more elaborate information showing growth period of the quinoa genotypes that ranged from 65 to 98 days in 1999 and 72 to 123 days in 2000. Crop growth durations were shorter than those reported from the Andean region, which ranged from 110 to 190 days (Jacobsen and Stølen, 1993). The highest yields per plant for the two seasons were obtained from Cv. Narino (26.5 g and $11.8 \mathrm{~g}$ per plant) and the second highest yielding genotype was CICA-17, which gave 25.7 $\mathrm{g}$ and $9.2 \mathrm{~g}$ in 1999 and 2000, respectively. The late-maturing varieties grew taller, accumulated more biomass and consequently resulted in high seed yields. The overall grain yields of the cultivars for the two seasons ranged from 1.583 to $2.097 \mathrm{t} / \mathrm{ha}$, which were comparable with yield obtained from the native quinoa-growing regions. The study identified Narino, CICA-127, CICA-17 and ECU-420 as superior cultivars in terms of biomass production and seed yield because they yielded as much as $4 \mathrm{t} / \mathrm{ha}$. The study also indicated that adaptability and yield stability studies across several Kenyan environments could be useful in order to recommend different quinoa genotypes for cultivation in different agro-ecological zones.

While there had been additional studies on the use of other rotational crops to suppress root nematodes (Kimenju et al., 2008), the promising genotypes evaluated were not picked up for direct release to farmers or for use in further breeding work. The status of the germplasm of these early genotypes is not known but could perhaps be found in the national gene bank. This could be attributed to a lack of coordinated research that takes all stakeholders on board. There is a need to raise awareness of the benefits of quinoa and its potential for marginal environments, and for coordinated research in various disciplines including physiology, breeding and agronomy to stimulate the spread and adoption of quinoa. A value chain approach would be a better option once the suitable varieties have been released. Unlike the approach of focusing exclusively on the production level, the value chain approach employs more holistic agribusiness strategies of considering the sequence of key activities and their supporting economic activities at the various levels of the chain (Rillo and Nugroho, 2016), such as availability of production inputs, production and processing of the produce, marketing and distribution of the produce and its products. This approach would therefore link quinoa production 
with the food-processing industry and services sectors of the economy along the supply-value chain and market network. The approach is likely to allow production that is aligned with demand as awareness of the benefits of quinoa grows and to avoid oversupply that can negate farmers' interest in adopting this new crop into their farming system.

On the other hand, although quinoa is not currently grown in Kenya, some quinoa products are found in major supermarkets in large towns and cities, imported mainly from Europe and the Andean region whose main customers are the affluent. To promote its utilization by local populations, the crop needs to be produced locally as well. A legal framework and the necessary institutions exist in Kenya to regulate plant genetic material for sustainable management and utilization of genetic resources for the benefit of the people. These include the Kenya Plant Health Inspection Service (KEPHIS), National Environmental Monitoring Authority (NEMA) through the Environmental Management and Coordination Act (Conservation of Biological Diversity and Resources, Access to Genetic Resources and Benefit Sharing) and the National Council for Science and Technology (NCST).

\subsection{Malawi}

\subsubsection{Agronomic studies}

The objective of quinoa adaptation studies in Malawi was to introduce and evaluate diverse quinoa genotypes for plant-growth and grain-yield performance in two contrasting environments. Thirteen quinoa varieties were introduced in Malawi in 2012 through a collaborative research project involving Lilongwe University of Agriculture and Natural Resources (LUANAR) and Washington State University (WSU). The genotypes originated from South American countries (but were obtained from ex-situ collections in the United States of America [USA]). Some genotypes had been bred in the USA and Denmark (Table 2). Seeds were supplied to LUANAR by the WSU.

The quinoa genotypes were evaluated under different Malawi environments and conditions in three stages: (i) preliminary evaluation of the genotypes conducted under irrigated conditions at two sites, Bunda and Bembeke; (ii) evaluation of the genotypes under rainfed conditions at one location, Bunda; and (iii) evaluation of the genotypes in six environments in four districts - Dowa, Ntchisi, Nkhotakota and Salima (Figure 4 and Table 3).

The preliminary evaluation (Maliro et al., 2017) was limited to two sites (research stations) to allow researchers to get acquainted with the crop, monitor its growth and observe if there would be any pests and diseases that would significantly affect its growth and yield performance. The trials evaluated 11 of the 13 genotypes (G1 to G11 which had enough seed) laid out in replicated experiments at the Bunda Campus of LUANAR and at Bembeke Agricultural Research Substation in Dedza district. The Bunda Campus is located at $14^{\circ} 12^{\prime} \mathrm{S}$ and 33 $46^{\prime} \mathrm{E}, 1200$ metres above sea level (m.a.s.l), receives $1030 \mathrm{~mm}$ /year of rainfall, and with a mean temperature of $20^{\circ} \mathrm{C}$ ). Bembeke Agricultural Research Substation is located at $14^{\circ} 35^{\prime} \mathrm{S}$ and $34^{\circ} 43^{\prime} \mathrm{E}$, at $1600 \mathrm{~m}$.a.s.l., receives $1500 \mathrm{~mm}$ /year of rainfall and with a mean temperature of $15^{\circ} \mathrm{C}$ ). The Bunda site represented a relatively warm environment while Bembeke represented the relatively cool environment of central Malawi. The experiments were conducted from July to mid-October in 2012, under irrigated conditions (Maliro et al., 2017, Kathabwalika et al., 2013). 


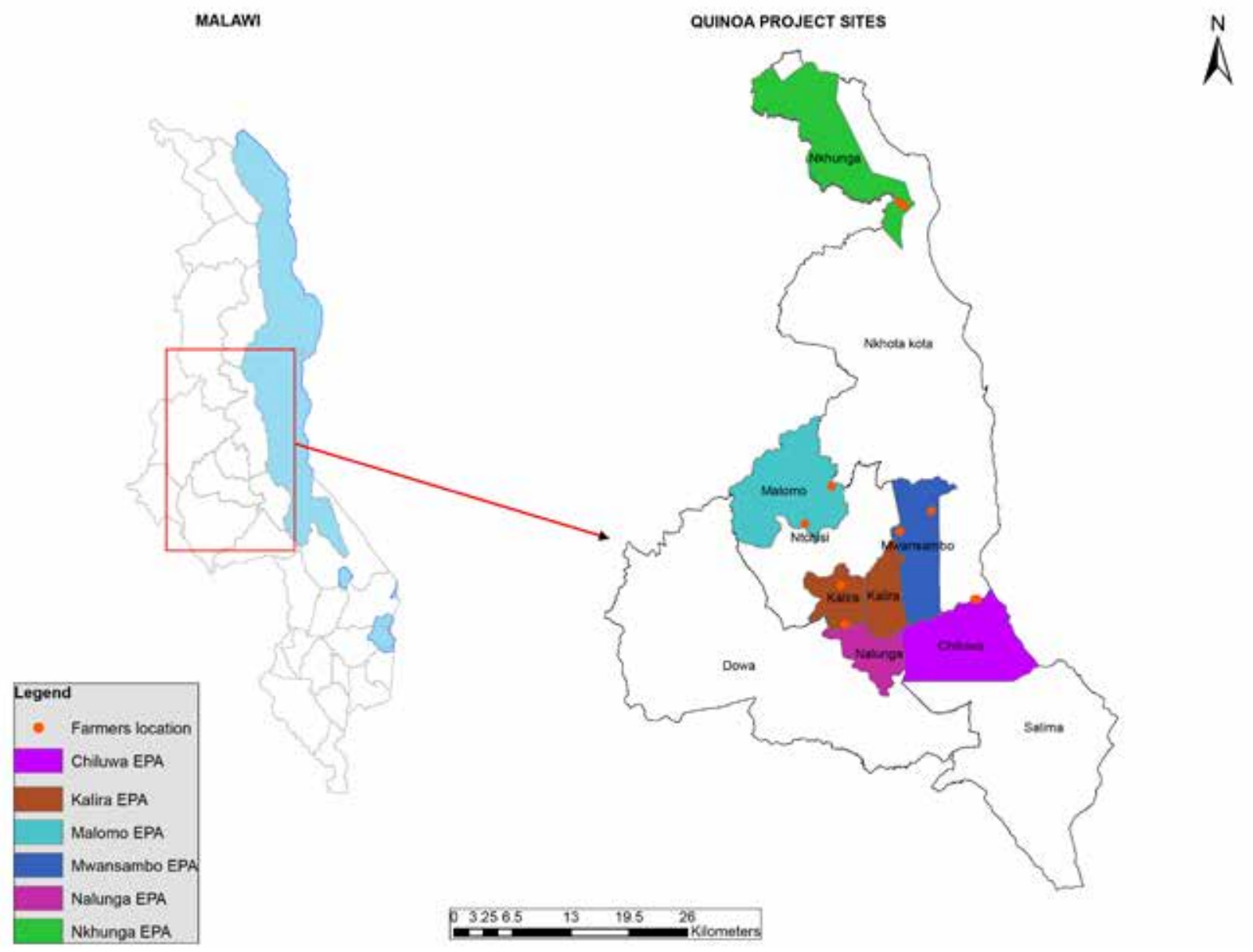

Figure 3: Map showing quinoa's adaptability experimental sites in Malawi during the 2014-2016 experimental periods

(Source: Adapted from Malawi free map, free blank map, free outline map, free base map boundaries, districts, names (d-maps.com) and modified by Maliro, M.F.A., Muhota, P.T., Leong, R., Museka, R. and Jere, Z. (Unpublished, 2017). Lilongwe University of Agriculture and Natural Resources, Lilongwe, Malawi. Map prepared for a presentation on the proposal to release six varieties of quinoa (Chenopodium quinoa Willd) for production in Malawi, presented to the Agricultural Technology Clearing Committee of the Ministry of Agriculture, Lilongwe, Malawi.

Table 2: List of quinoa genotypes introduced and evaluated for adaptability in six different environments of central Malawi

\begin{tabular}{|l|l|l|l|l|}
\hline \multicolumn{2}{|l|}{ Genotype } & Origin & Notes \\
\hline 1 & G1 & Black-seeded & Colorado, US & $\begin{array}{l}\text { Developed from a cross between Chenopodium } \\
\text { quinoa and Chenopodium berlandieri; very tall } \\
\text { variety (>2 m tall) }\end{array}$ \\
\hline 2 & G2 & $\begin{array}{l}\text { Brightest Brilliant } \\
\text { Rainbow }\end{array}$ & Oregon, US & Bred by Frank Morton of Wild Garden Seeds \\
\hline 3 & G3 & Bio-Bio & Chile & \\
\hline 4 & G4 & Cherry Vanilla & Oregon, US & Bred by Frank Morton of Wild Garden Seeds \\
\hline 5 & G5 & Multi-Hued & $\begin{array}{l}\text { British Columbia, } \\
\text { Canada }\end{array}$ & \\
\hline 6 & G6 & Red Head & Oregon, US & Bred by Frank Morton of Wild Garden Seeds \\
\hline 7 & G7 & QQ74 & Chile & Heat-tolerant Chilean landrace \\
\hline 8 & G8 & Puno & Denmark & Bred by Sven-Erik Jacobsen \\
\hline 9 & G9 & Titicaca & Denmark & Bred by Sven-Erik Jacobsen \\
\hline 10 & G10 & Ecuadorian & Ecuador & \\
\hline
\end{tabular}




\begin{tabular}{|l|l|l|l|l|}
\hline 11 & G11 & $\begin{array}{l}\text { Inca Red } \\
\text { (Pasankalla) }\end{array}$ & Bolivia & Member of the 'Salares' ecotype of quinoa \\
\hline 12 & G12 & QQ065 & Chile & $\begin{array}{l}\text { From extremely rainy region of Chile }(>2500 \\
\text { mm); shown high resistance to postharvest } \\
\text { sprouting }\end{array}$ \\
\hline 13 & G13 & Rosa Junin & Peru & \\
\hline
\end{tabular}

The next stage evaluated the eleven genotypes (G1 to G11) during the rainy season from December to March 2012/2013. The evaluation of nine genotypes (G1 to G9) was repeated in 2013/2014 as rainfed experiments at the Bunda Campus of LUANAR. The rainfed experiment was limited to Bunda Campus on-station as the crop proved to experience more challenges when grown under irrigation. To extend the rainfed evaluation to on-farm sites would require better preparation for farmers to reserve pieces of land for experimental trials and labour resources to be able to manage experimental plots. Four genotypes were dropped from further evaluation on account of poor performance and limited seed availability.

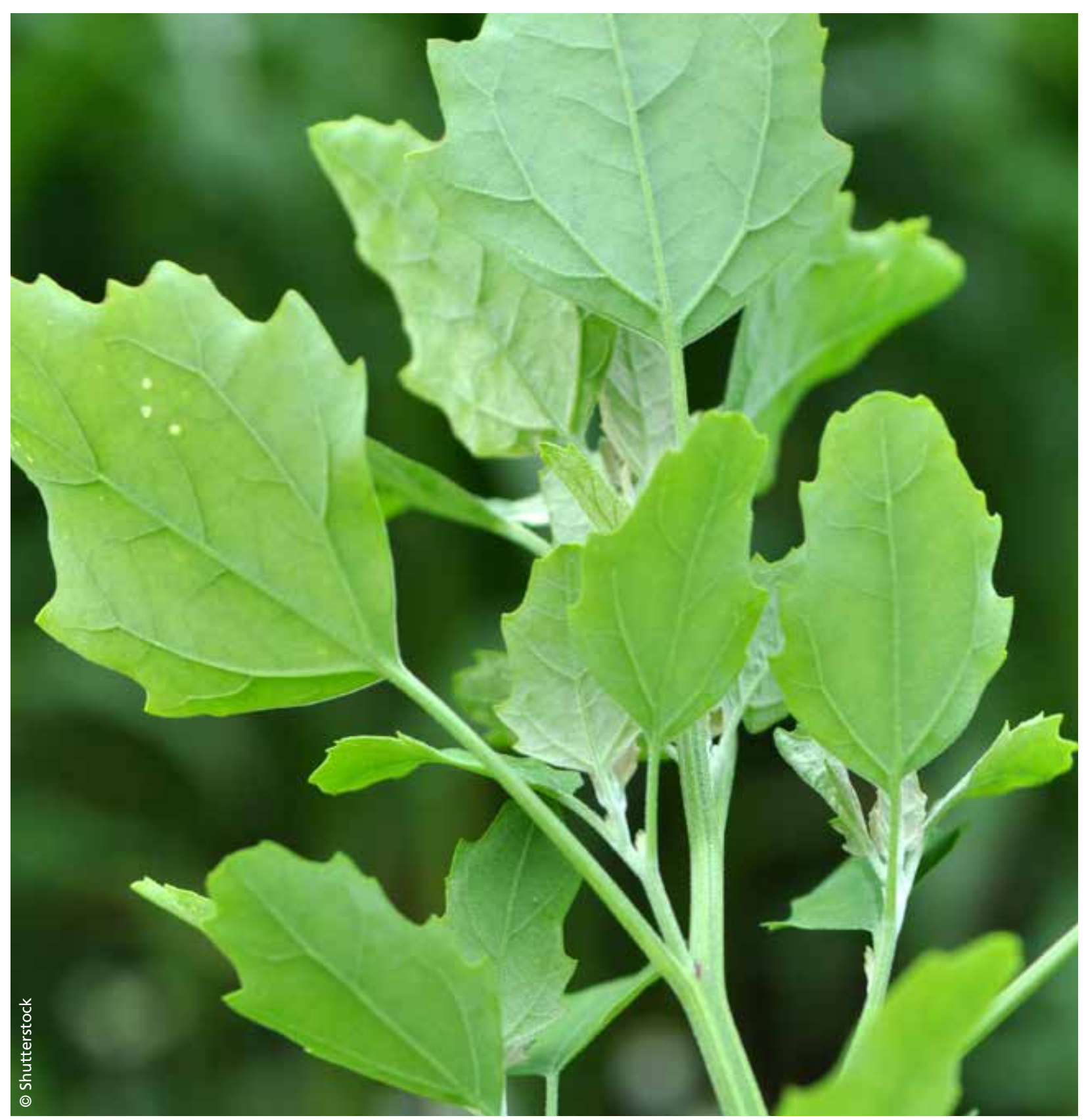


In the third stage, with support from the Royal Norwegian Embassy, LUANAR and Total Land Care (TLC), a non-governmental organization that is working on agricultural development projects, developed a five-year collaborative research project (2014 to 2019) under which quinoa was included as a crop to promote for food and nutritional security among rural communities of Central Malawi (Figure 3). The promising nine genotypes (G1 to G9 in Table 3) from the first stages were tested at six sites of varying altitudes in the central region of Malawi (Table 3, Figure 3). The sites were within the impact area of TLC at the time the project proposal was developed and took advantage of existing networks such as government agricultural extension workers, local leaders and the farming communities. The experiment environments (details are provided in Figure 3 and Table 3 ) varied from low altitude $\left(470,521,503\right.$ and 515 m.a.s.l) and warm $\left(25\right.$ to $\left.28^{\circ} \mathrm{C}\right)$ (Chiluwa EPA of Salima district and Nkhunga EPA of Nkhotakota district), medium altitude (555 and 617 m.a.s.l.) and mildly warm $\left(23\right.$ to $\left.25^{\circ} \mathrm{C}\right)$ (Mwansambo EPA of Nkhotakota district), to high altitude (1 049, 1267 and 1077 m.a.s.l.) and cold (18 to $22^{\circ} \mathrm{C}$ ) (Nalunga EPA of Dowa district and Malomo EPA of Ntchisi district). In each site, with the help of TLC field coordinators, two farmers that had fields close to a water source for irrigation were identified and requested to host the evaluation experiments. Each farmer hosted a complete replicated experiment and the owners provided labour for the management of the plots under the guidance of TLC field coordinators. Field coordinators were trained by the LUANAR research team on quinoa management and data collection prior to implementing the experiments. The nine genotypes were evaluated in a randomized complete block design (RCBD) from May to August, and repeated from September to November 2014, 2015 and 2016. Data on plant growth, maturity and grain yield were collected by the field coordinators while farmers provided their opinions on growth characteristics of the genotypes such as leaf for the leafy vegetable, maturity duration and grain yield during field days and group discussions.

Results from these introduction and evaluation trials in Malawi showed that cold temperatures slowed down growth within the first 21 days at the Bunda site and within the first 60 days in the case of the Bembeke site. Quinoa plants at the cooler Bembeke site had a mean height of $50 \mathrm{~cm}$ compared with $90-100 \mathrm{~cm}$ at Bunda. The genotypes took 90 to 112 days (with an overall mean of 90 days) to mature at Bunda, while at Bembeke the same genotypes took a mean range of 102 to 119 days to mature. Under these irrigated conditions, the genotypes with the highest (average) yield were Brightest Brilliant Rainbow (BBR), Cherry Vanilla, Multi-Hued and QQ74 that yielded up to 1.9 to 3 tonnes/ha.

Table 3: Description of locations/environments where multilocational evaluation trials of quinoa were conducted in Malawi (2014 and 2015) (See Figure 3 for location of the sites)

\begin{tabular}{|c|c|c|c|}
\hline $\begin{array}{l}\text { Environment } \\
\text { (E) }\end{array}$ & Name of site & $\begin{array}{l}\text { Altitude in metres above } \\
\text { sea level (m.a.s.I.) and } \\
\text { geographical coordinates }\end{array}$ & $\begin{array}{l}\text { Temperature (from May } \\
\text { to August) \& rainfall }\end{array}$ \\
\hline E1 & Nkhunga EPA (Nkhotakota District) & $\begin{array}{l}503 \mathrm{~m} \mathrm{\&} 515 \mathrm{~m} \\
\mathrm{~S} 12^{\circ} 35.383^{\circ} \mathrm{E} 034^{\circ} 08.673^{\circ} \\
\mathrm{S} 12^{\circ} 35.338^{\circ} \mathrm{E} 034^{\circ} 08.618^{\circ}\end{array}$ & $\begin{array}{l}\text { Warm }\left(25-28{ }^{\circ} \mathrm{C}\right) \\
1401 \text { to } 1500 \mathrm{~mm}\end{array}$ \\
\hline E2 & Malomo EPA (Ntchisi District) & $\begin{array}{l}1077 \mathrm{~m} \\
\mathrm{~S} 13^{\circ} 15.408^{\circ} \mathrm{E} 033^{\circ} 52.549^{\circ} \\
\mathrm{S} 13^{\circ} 17.155^{\circ} \mathrm{E} 034^{\circ} 07.155^{\circ}\end{array}$ & $\begin{array}{l}\text { Cool }\left(18-22{ }^{\circ} \mathrm{C}\right) \\
1001 \text { to } 1200 \mathrm{~mm}\end{array}$ \\
\hline E3 & Chiluwa EPA (Salima District) & $\begin{array}{l}470 \mathrm{~m} \& 521 \mathrm{~m} \\
\mathrm{~S} 13^{\circ} 27.040^{\circ} \mathrm{E} 034^{\circ} 15.559^{\circ}\end{array}$ & $\begin{array}{l}\text { Warm }\left(25-28^{\circ} \mathrm{C}\right) \\
1001 \text { to } 1200 \mathrm{~mm}\end{array}$ \\
\hline E4 & Nalunga EPA (Dowa District) & $\begin{array}{l}1049 \mathrm{~m} \mathrm{\&} 1267 \mathrm{~m} \\
\mathrm{~S} 13^{\circ} 36.258^{\circ} \mathrm{E} 034^{\circ} 00.642^{\circ} \\
\mathrm{S} 13^{\circ} 36.098^{\circ} \mathrm{E} 034^{\circ} 00.356^{\circ}\end{array}$ & $\begin{array}{l}\text { Cool }\left(18-22{ }^{\circ} \mathrm{C}\right) \\
1001 \text { to } 1200 \mathrm{~mm}\end{array}$ \\
\hline E5 & Kalira 2 EPA (Ntchisi District) & $\begin{array}{l}1456 \mathrm{~m} \\
\mathrm{~S} 13^{\circ} 30.205^{\circ} \mathrm{E} 033^{\circ} 57.691^{\circ} \\
\mathrm{S} 13^{\circ} 25.620^{\circ} \mathrm{E}^{\circ} 33^{\circ} 58.150^{\circ}\end{array}$ & $\begin{array}{l}\text { Cold }\left(16-20^{\circ} \mathrm{C}\right) \\
1001 \text { to } 1200 \mathrm{~mm}\end{array}$ \\
\hline E6 & $\begin{array}{l}\text { Mwansambo EPA (Nkhotakota } \\
\text { District) }\end{array}$ & $\begin{array}{l}555 \mathrm{~m} \mathrm{\&} 617 \mathrm{~m} \\
\mathrm{~S} 13^{\circ} 14.199^{\circ} \mathrm{E} 034^{\circ} 10.392^{\circ} \\
\mathrm{S} 13^{\circ} 09.252^{\circ} \mathrm{E}^{\circ} 33^{\circ} 56.248^{\circ}\end{array}$ & $\begin{array}{l}\text { Mildly warm }\left(23-25^{\circ} \mathrm{C}\right) \\
1001 \text { to } 1200 \mathrm{~mm}\end{array}$ \\
\hline
\end{tabular}


A comparison between rainfed and irrigated quinoa growing showed that rainfed (of $1117 \mathrm{~mm}$ ) trials at Bunda had the genotypes maturing in 75 to 90 days, earlier than when grown under irrigated season/conditions (90 to 112 days). Malawi's rain season is in summer (November to March) when temperatures are at their highest and plant growth is the fastest. Under rainfed conditions at Bunda, grain yields were as high as 1723 to $2380 \mathrm{~kg} / \mathrm{ha}$ by cv. Black-seeded, 1110 to $2096 \mathrm{~kg} / \mathrm{ha}$ by MultiHued and 816 to $2076 \mathrm{~kg} / \mathrm{ha}$ by Bio-Bio $(\mathrm{P} \leq 0.001)$. A notable reduction in yields was recorded from as high as 1697 to $3000 \mathrm{~kg} / \mathrm{ha}$ realized under irrigated conditions to as low as 550 to $2406 \mathrm{~kg} / \mathrm{ha}$ under rainfed conditions.

Results from the multilocation trials conducted with support from the Royal Norwegian Embassy in Lilongwe under a project known as 'Management for Adaptation to Climate Change II (MACC II)', implemented by TLC and LUANAR, showed that quinoa can grow well in varying agro-ecological regions of Malawi under irrigated conditions (rainfed growing in these sites is yet to be conducted in the next phase of the project). The maturity period varied $(\mathrm{p}<0.001)$ among sites, with quinoa genotypes in the low-altitude sites (Chiluwa EPA in Salima (E3) and Nkhunga EPA in Nkhotakota (E1)) maturing earliest (within 90 days), while those in the mid-altitude sites (Mwansambo EPA in Nkhotakota (E6)) matured within 100 to 110 days and those in the relatively high-altitude sites (Nalunga in Dowa (E4), Kalira 2 (E5) and Malomo (E2) in Ntchisi) took up to 120 days on average to mature. No significant variation $(\mathrm{P}=0.05)$ and no genotype $\mathrm{x}$ environment interaction in maturity period were observed among the genotypes.

Plant height (for the same genotype) at maturity stage differed significantly among sites $(\mathrm{p}<0.001)$ but not among genotypes $(\mathrm{p}=0.815)$ (within the same site) and there were no site/Environment $x$ genotype interaction effects $(p=0.068)$. Environment therefore had a significant influence on quinoa as reflected in the variation in plant height observed across the sites. The plants grew tallest in Mwansambo, Nalunga and Kalira EPAs followed by Chiluwa and Malomo, while Nkhunga (the variation in altitude and temperature of the different sites is shown in Table 3) had the shortest plants overall. The same trend was reflected in panicle length, which also correlated positively with grain yield (Maliro et al., 2017).

Grain yields (Figures 4 and 5$)$ varied $(\mathrm{p}<0.001)$ among sites and with significant site/Environment $\mathrm{x}$ genotype interactions. The highest yielding genotypes in the low-altitude and warm ecological area were Brightest Brilliant Rainbow (2 $669 \mathrm{~kg} / \mathrm{ha})$ and Multi-Hued (2 $018 \mathrm{~kg} / \mathrm{ha})$ in Chiluwa EPA, Cherry Vanilla (4 $141 \mathrm{~kg} / \mathrm{ha}$, Multi-Hued (3 $203 \mathrm{~kg} / \mathrm{ha}$ ) and Bio-Bio (2 $630 \mathrm{~kg} / \mathrm{ha})$ in Nkhunga. For the mid-altitude area in Mwansambo, Bio-Bio (4 $290 \mathrm{~kg} / \mathrm{ha}$ ), Puno (3 $982 \mathrm{~kg} / \mathrm{ha}$ ), QQ74 (3 $721 \mathrm{~kg} /$ ha) and Cherry Vanilla (3 $701 \mathrm{~kg} / \mathrm{ha}$ ) were the highest yielding. In Nalunga it was Cherry Vanilla (4 $141 \mathrm{~kg} / \mathrm{ha})$, Red head (3685 kg/ha) and Multi-Hued (3 $529 \mathrm{~kg} / \mathrm{ha})$; in Kalira 2 it was BBR (1 $302 \mathrm{~kg} /$ ha), Bio-Bio (911 kg/ha) and Titicaca $(911 \mathrm{~kg} / \mathrm{ha})$; while in Malomo the highest yielding genotypes were BBR (4 $583 \mathrm{~kg} / \mathrm{ha}$ ), Bio-Bio (4 $375 \mathrm{~kg} / \mathrm{ha}$ ), Multi-Hued (4 $323 \mathrm{~kg} / \mathrm{ha}$ ) and Cherry Vanilla (3 984 $\mathrm{kg} / \mathrm{ha})$ in the high-altitude sites.

The grain-yield pattern was consistent across the six sites and genotypes tested in the subsequent year (2015), with Nalunga, Malomo and Kalira 2 (the high-altitude sites) emerging as the best environments for quinoa production in Malawi. The significant variation across the environments was attributed to temperature, whereby the high-altitude sites that experience lower temperatures within the range of 10 to $25^{\circ} \mathrm{C}$ were the best environments for quinoa (Jacobsen et al., 2003). The sites that had lower grain yields experience temperatures of above $25^{\circ} \mathrm{C}\left(25\right.$ to $\left.28^{\circ} \mathrm{C}\right)$ on average. Temperatures higher than $38^{\circ} \mathrm{C}$ (Bazile, 2015) lead to high flower abortion and consequently reduce grain yields in quinoa (Garcia et al., 2015). There is a need to study further environmental factors like soil fertility parameters and irrigation water regimes practised at different sites as dictated by water availability and rates of evapotranspiration. 


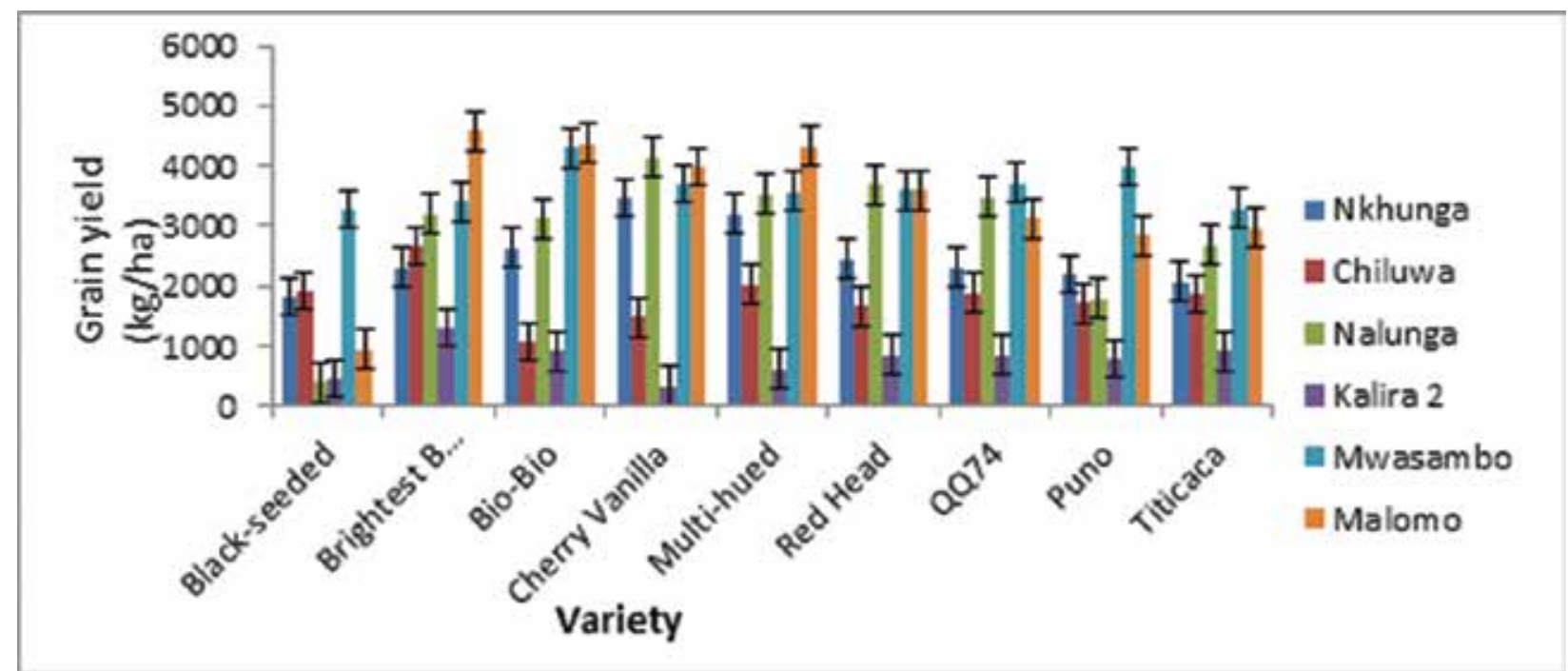

Figure 4: Grain yield ( $\mathrm{kg} / \mathrm{ha}$ ) of quinoa genotypes evaluated at six different sites in Central Malawi during the 2014 irrigated season (May to August 2014) (Fprob. $=0.002$ for genotype, $<0.001$ for sites)

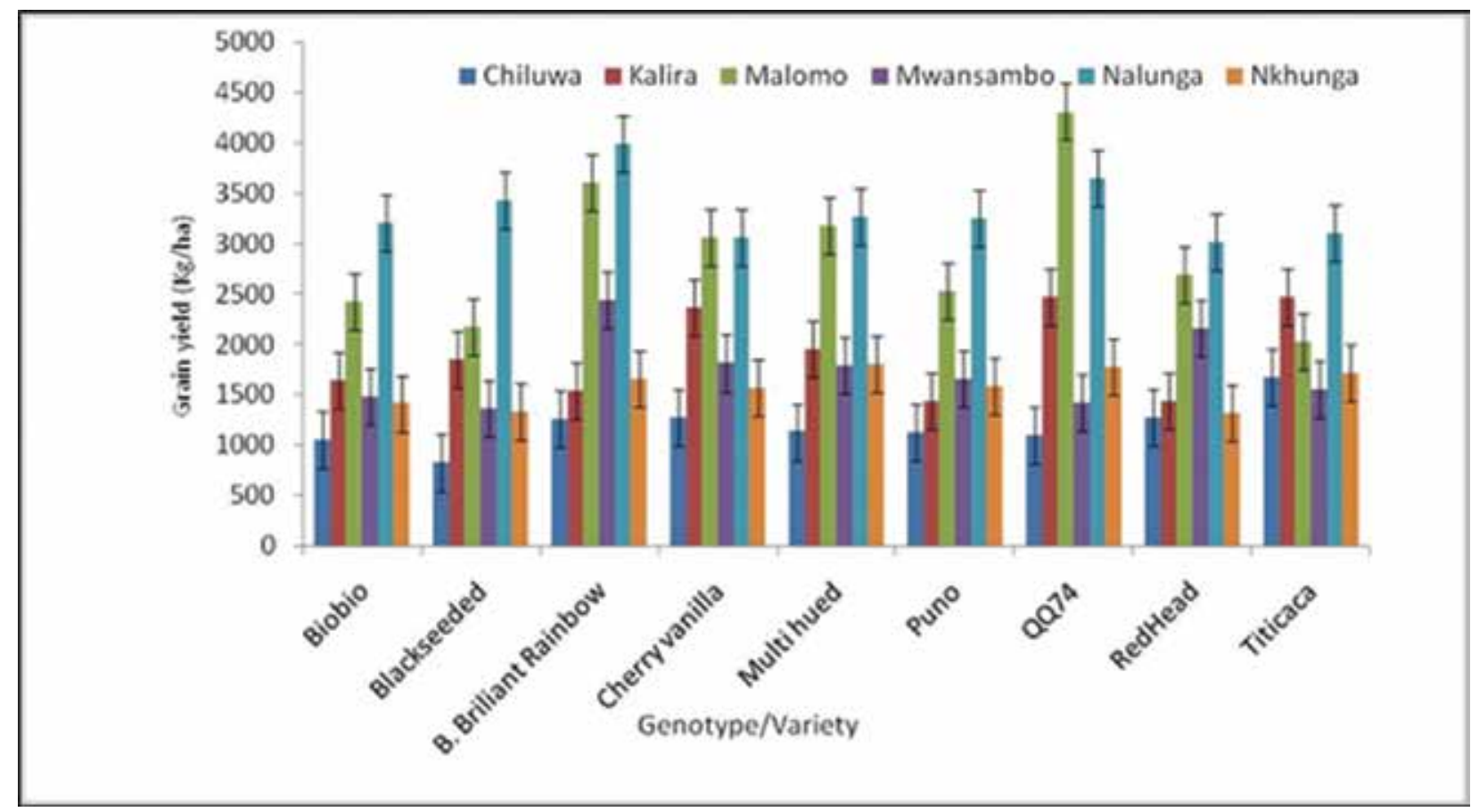

Figure 5: Grain yield (kg/ha) of quinoa genotypes evaluated at six different sites in Central Malawi during the 2015 irrigated season (May to August 2015) (Fprob. $=<0.089$ for genotype, $<0.001$ for sites, < 0.967 for genotype $x$ site interaction; SED = 242; LSD = 477.5)

Other agronomic studies on quinoa that have been conducted by LUANAR in undergraduate projects at Bunda Campus include time of planting for growing rainfed quinoa, sowing methods, plant spacing (plant density), and organic and inorganic fertilizer application rates. Results have shown that sowing soon after the first rains (normally in December and January) results in better plant establishment and grain yield than sowing a month later (Chakholoma, 2016). The main challenge was that the crop matured before the end of the rainy season, leading to sprouting of seeds before harvesting. Plant spacing of $10 \mathrm{~cm} \times 20 \mathrm{~cm}, 20 \mathrm{~cm} \times 20 \mathrm{~cm}, 10 \mathrm{~cm} \times 50 \mathrm{~cm}$ (plant and row spacing) gave the highest grain yields (Lipenga, 2016), however this would vary with variety. The genotypes 
appeared to have a high capacity for adapting their growth to the available space, such that in wide spacing the genotypes appeared to develop more branches. The results also suggest that optimal plant spacing may vary with genotype, plant nutrition and branching characteristics, all of which require further investigation.

\subsubsection{Variety release for use by farmers}

One of the accomplishments of quinoa research in Malawi has been the approval of seven genotypes as varieties by the Agricultural Technology Clearing Committee (ATCC) of the Ministry of Agriculture, Irrigation and Water Development. Data generated from the agronomic experiments conducted from 2014 to 2016, demonstrated that it was possible to produce quinoa in Malawi. In August 2017, the ATCC approved the release of seven varieties of quinoa that included Brightest Brilliant Rainbow, Bio-Bio, Black seeded, Cherry Vanilla, Multi-Hued, QQ74 and Titicaca based on their consistent and outstanding performance in the various environments tested, with grain yields ranging from $1.2 \mathrm{t} / \mathrm{ha}$ to $4.0 \mathrm{t} / \mathrm{ha}$. To popularize the varieties, the research team is currently working with the Ministry's Seed Services Unit in developing a system for seed multiplication and a certification process.

\subsubsection{Quinoa in nutritional programmes of rural communities}

The quinoa component of the Management for Adaptation to Climate Change II project of Total Land Care was expected to contribute to increasing the access of under-five children and expectant and lactating mothers to nutrient-dense food products in the impact areas. The project therefore promoted the use of quinoa among farming community households at the sites (Nalunga EPA in Dowa district and Nkhunga EPA in Nkhotakota district) where the genotypes were evaluated.

It is important to recognize that food insecurity is mostly localized, either by geographic location or by a community, or even by social groups within a given community. For example, the proportion of people who are food insecure is higher in rural areas than in urban areas (IAASTD, 2009). These challenges are aggravated by gender and other inequalities that disadvantage specific sections of the population such as women and children. While farmers in the food-insecure areas face mounting population pressure, declining landholding and deteriorating natural resource bases, gender inequalities also play a significant role in accounting for food insecurities in the case of women and children, who are mostly the vulnerable in households (IAASTD, 2009).

The promotional activities therefore included the distribution of quinoa seed ( 20 to $50 \mathrm{~g}$ per household) to 120 interested households, training of two women groups (10 women in Nalunga EPA and 15 women in Nkhunga EPA) in the processing of quinoa grain (specifically washing to remove saponin) and development of local recipes into products (such as nsima, cakes and beverages). Annual stakeholder meetings and field days were organized for farmers and other stakeholders to appreciate the quinoa crop and food products prepared from the grain. Individual households started growing the quinoa in their vegetable gardens for both the leafy vegetable (from 30 to 60 days from emergence) and the grain.

No studies have been conducted as yet on the impact leaf harvesting has on the grain yield. In the latest reporting, farmers were growing separate plots of quinoa for their leafy vegetables. During the 2014/15 winter cropping season, one village in Nalunga EPA where 28 farmers grew quinoa in plots of various sizes, produced more than $1000 \mathrm{~kg}$ (1 tonne) of quinoa grain under irrigation, which demonstrated the significant interest shown by many of the farmers in growing the crop. The communities indicated that they preferred quinoa leaves as a vegetable as in their opinion quinoa tasted better than the customary Amaranthus leaves. Quinoa can therefore be promoted for both the grain and the leaf. In that regard, research needs to include selection of varieties for leaf vegetables as well. 


\subsection{Ethiopia}

\subsubsection{First introduction and evaluation trials of quinoa in Ethiopia}

Quinoa was first introduced in Ethiopia in 2002 through the Ethiopian Institute of Agricultural Research (EIAR) with 24 genotypes originating from South American countries (reported by BerhanuAmsalu Fenta of EIAR in a presentation at a quinoa training workshop organized by FAO in 2014 unpublished). Table 4 provides a list of these genotypes and information on institutions and countries of origin. This formed part of a project initiated by the Danish International Development Agency (DANIDA) (Mujica et al., 2001). Following a process of seed multiplication, 16 of the genotypes had adequate seed for evaluation in multiple sites, while eight had poor germination (also highlighted in Table 4). From 2003 to 2005 the 16 genotypes were tested in four sites, namely Melkassa - high altitude, Ziway - mid to high altitude, Mieso - low altitude and Goffa - low altitude (Figure 6), representing different agro-ecological zones of the country under rainfed conditions. An Amaranthus variety was included in the test trials as a check as it is a close relative of quinoa species that are grown in Ethiopia and the rest of Africa (reported by Berhanu-Amsalu Fenta of EIAR in a presentation at a quinoa training workshop organized by FAO in 2014 - unpublished).

Table 4: List of quinoa genotypes (and institutions that provided the germplasm) that were introduced (in 2000) and evaluated for adaptability in different environments of Ethiopia

\begin{tabular}{|c|c|c|c|}
\hline \multicolumn{2}{|c|}{ Genotype } & \multirow{2}{*}{$\begin{array}{l}\text { Origin (Institution) } \\
\text { Cusco }\end{array}$} & \multirow{2}{*}{$\frac{\text { Country }}{\text { Peru }}$} \\
\hline 1 & CICA-127 & & \\
\hline 2 & CICA-17 & Cusco & Peru \\
\hline 3 & Salcedo & INTA & Puno - Peru \\
\hline 4 & Kamiri & IBTA & Bolivia \\
\hline 5 & Jujuy & UNA & Argentina \\
\hline 6 & Baer-II-U & Concepcion & Chile \\
\hline 7 & RU-2-PQCIP & DANIDA-UNA & England \\
\hline 8 & RU-5-PQCIP & DANIDA-UNA & England \\
\hline 9 & NL-6-PQCIP & DANIDA-UNA & Holland \\
\hline 10 & E-DK-4-PQCIP & DANIDA-UNA & Denmark \\
\hline 11 & G-205-95-PQCIP & DANIDA-UNA & Denmark \\
\hline 12 & Sayana & IBTA & Bolivia \\
\hline 13 & Ingapirca & INIAP & Ecuador \\
\hline 14 & 03-21-079BВ & UNA & Puno - Peru \\
\hline 15 & 03-21-072RM & UNA & Puno - Peru \\
\hline 16 & Canchones & UAP & Iquique - Chile \\
\hline 17 & *Huariponcho & CRIDER & Puno - Peru \\
\hline 18 & *Kancolla & UNA & Peru \\
\hline 19 & *Narino & INTA & Pasto - Colombia \\
\hline 20 & *Ratuqui & IBTA & Bolivia \\
\hline 21 & *Real & IBTA & Bolivia \\
\hline 22 & *ECU-420 & INIAP & Ecuador \\
\hline 23 & *02-EMBRAPA & EMBRAPA & Brazil \\
\hline 24 & *IIlpa & INIA & Puno - Peru \\
\hline
\end{tabular}

${ }^{\star}$ Genotypes that displayed poor germination during the initial sowing in Ethiopia and were not evaluated in multiple sites 


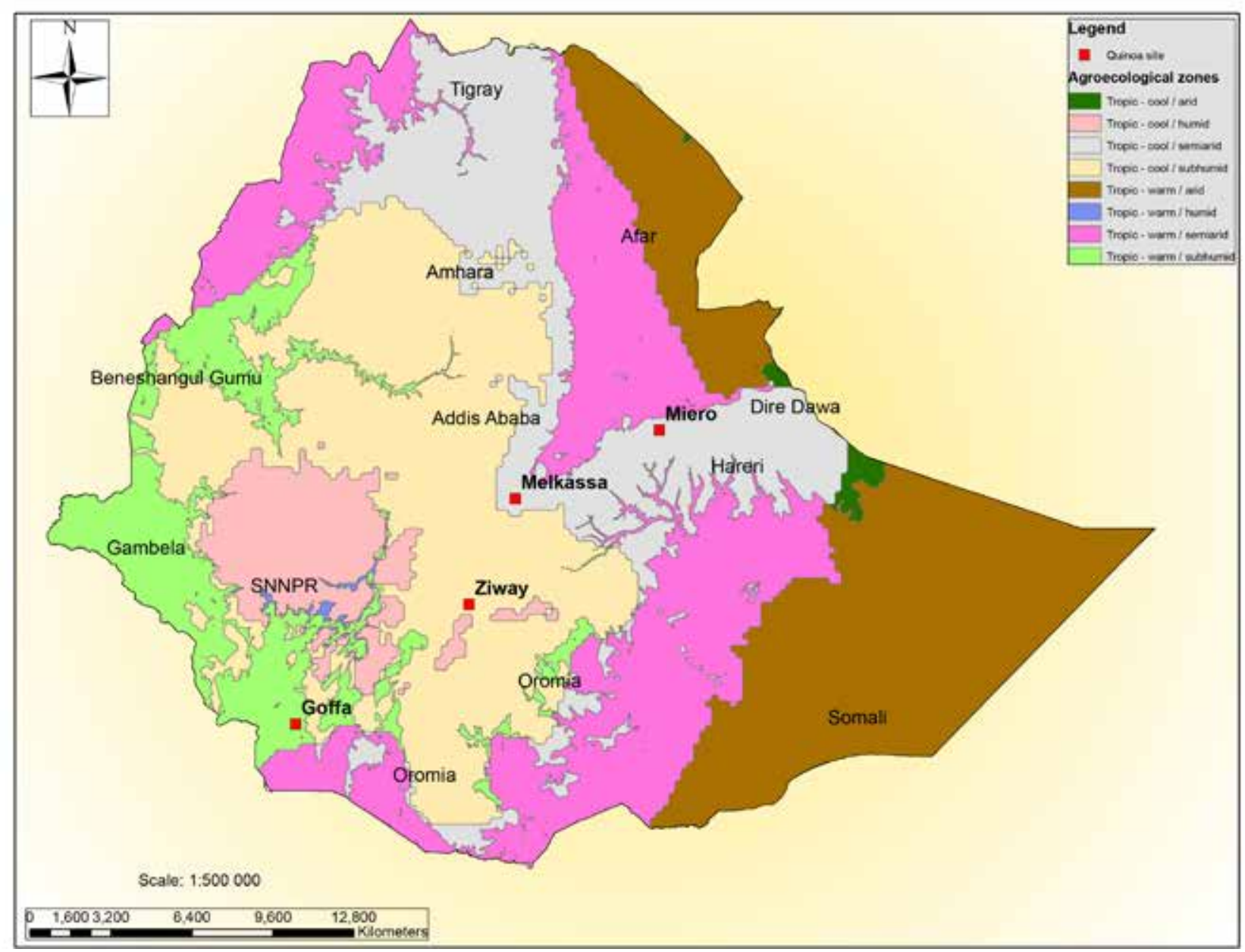

Figure 6: Map of Ethiopia showing locations where early quinoa trials were conducted (2003 to 2005) by the Ethiopian Institute of Agricultural Research.

Adapted from Tilahun Amede, Christopher Auricht, Jean-Marc Boffa, John Dixon, Thilak Mallawaarachchi, Mandi Rukuni and Tilaye Teklewold-Deneke. 2015. The Evolving Farming and Pastoral Landscapes in Ethiopia: A Farming System Framework for Investment Planning and Priority Setting, ACIAR, Canberra.

(Full text accessible at https://www.researchgate.net/publication/296525932)

\subsubsection{Promising plant growth and yield results}

Performance of the tested genotypes showed that two of the 24 genotypes did well across the four sites in terms of plant growth and grain yield. Drought was reported in the first season (2002/2003) that significantly affected performance of the genotypes with the exception of two varieties (G-205-95 and RU-2RU-2) that survived. Differences in flowering and maturity time between the four environments were recorded for the two genotypes, but in general they flowered between 40 to 46 days and matured 73 to 88 days from sowing (Table 5). Flowering and maturity were earliest at Ziway (flowering at 40 and 39 days and maturing at 81 and 82 days) and Melkassa (flowering at 42 and 43 days and maturing at 81 days) compared with Mieso (flowering at 46 days and maturing at 87 and 88 days). However, at Goffa flowering was late (46 days as at Mieso) but maturity was the earliest (at 73 days). Studies in other countries like Malawi showed that late-flowering genotypes also tend to be late in maturing (Maliro et al., 2017). Early cessation of rains (drought) in Goffa might have induced early maturity in the genotypes. The significant variation in maturity performance across the four locations calls for selection of genotypes that would perform best in specific ecological zones. Early-maturing genotypes would be suitable for ecological zones that experience a short rainy season of two months. 
Table 5: Average performance in duration to flowering (days) and maturity (days) and grain yield $(\mathrm{kg} / \mathrm{ha}$ ) of two of the surviving quinoa genotypes evaluated in four locations of Ethiopia from 2003 to 2005 under rainfed conditions (Amsalu, 2014)

\begin{tabular}{|c|c|c|c|c|c|c|c|}
\hline \multirow{2}{*}{\multicolumn{2}{|c|}{ Location }} & \multicolumn{2}{|c|}{ Days to flowering } & \multicolumn{2}{|c|}{ Days to maturity } & \multicolumn{2}{|c|}{ Grain yield (kg/ha) } \\
\hline & & G-205-95* & $R U-2 R U-2 * *$ & G-205-95 & $R U-2 R U-2$ & G-205-95 & $R U-2 R U-2$ \\
\hline 1 & Melkassa*** & 42 & 43 & 81 & 81 & 1960 & 1864 \\
\hline 2 & Ziway**** & 40 & 39 & 81 & 82 & 2161 & 2100 \\
\hline 3 & Mieso***** & 46 & 46 & 87 & 88 & 1538 & 1537 \\
\hline 4 & Goffa $* * * * *$ & 46 & 46 & 73 & 73 & 1524 & 1548 \\
\hline \multicolumn{8}{|c|}{$\begin{array}{l}\text { Detailed identity of the genotypes: } \\
\text { * (i) G-205-95-PQCIP-DANIDA-UNA-Denmark } \\
* * \text { (ii) RU-2-PQCIP-DANIDA-UNA-England } \\
\text { Site characteristics: } \\
* * * \text { Rainfall }(1001 \text { to } 1250 \mathrm{~mm}) \text {, Altitude }(2001 \text { to } 2400 \mathrm{~m}) \text {, Temperature }\left(25.1 \text { to } 30^{\circ} \mathrm{C}\right) \text {; } \\
* * * * \text { Rainfall }(1001 \text { to } 1250 \mathrm{~mm}) \text {, Altitude }(1601 \text { to } 2000 \mathrm{~m}) \text {, Temperature }\left(25.1 \text { to } 30^{\circ} \mathrm{C}\right) \text {; } \\
* * * * * \text { Rainfall }(751 \text { to } 1000 \mathrm{~mm}) \text {, Altitude }(401 \text { to } 800 \mathrm{~m}) \text {, Temperature }\left(30.1 \text { to } 35^{\circ} \mathrm{C}\right)\end{array}$} \\
\hline
\end{tabular}

Grain yield from the two genotypes ranged from 1.5 to 2.0 t/ha (Table 4), with Ziway giving the highest yields of $2161 \mathrm{~kg} / \mathrm{ha}$ and $2100 \mathrm{~kg} / \mathrm{ha}$ for the two varieties, and Melkassa giving $1960 \mathrm{~kg} / \mathrm{ha}$ and $1864 \mathrm{~kg} / \mathrm{ha}$ for the two genotypes. Relatively low yields were obtained at Mieso, with $1538 \mathrm{~kg} / \mathrm{ha}$ and $1537 \mathrm{~kg} / \mathrm{ha}$ and at Goffa, with $1524 \mathrm{~kg} / \mathrm{ha}$ and $1548 \mathrm{~kg} / \mathrm{ha}$. The results from these evaluation trials clearly show two distinct zones for quinoa growing in Ethiopia - Melkassa and Ziway (being in the same group of locations for high yielding) and Mieso and Goffa (being in the same group of relatively low yielding, probably due to climatic conditions). The results showed that quinoa is relatively tolerant to drought and the two genotypes have potential for agro-ecological zones that experience moisture stress in the country. The two varieties were therefore recommended for wider testing in other similar locations of the country.

\subsubsection{Collaborative research with non-governmental organizations}

After 2006, another quinoa trial or documented promotion project was carried out in Ethiopia (from 2014 to 2015) when DanChurchAid (DCA) and EIAR developed a project titled 'Introduction, Adaptation and Promotion of Quinoa in Ethiopia' designed to test the performance of quinoa on farmers' fields. The project planned to include Oromia and Amhara, which are major regions (two districts from each region). Amhara region included North Wello Zone (Dahina) and Wage-himra Zone (Dahenna); Ormiya region; Bale Zone (GuraDamole), Borenna (Moyale) and two research sites under EIAR (Melkassa and Arsi-Negele). In each zone two farmers were proposed to host the evaluation trials of the promising varieties. The DCA in Ethiopia has since reported promising yields for the farmers engaged in these trials (De Jene, 2015). The engagement of other stakeholders that work with the farmers with a focus on food and nutritional security, promises to catalyse adoption of quinoa into the food systems. 


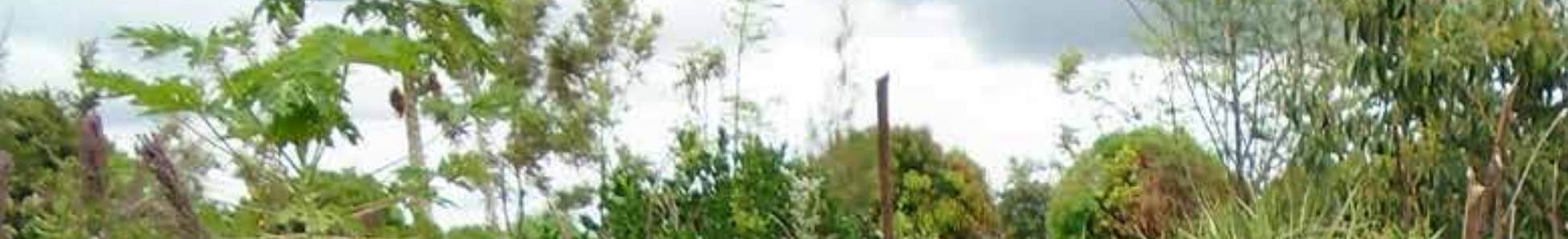
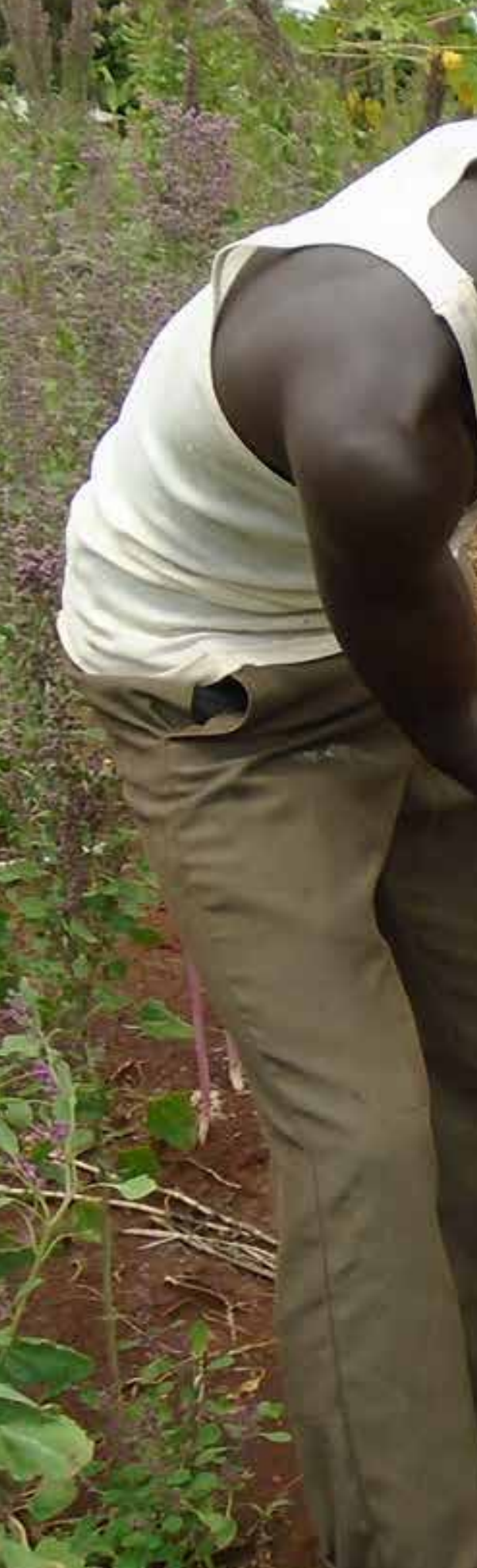

(2)

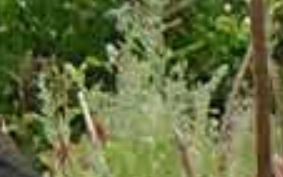

$\left.\frac{1}{2}+5\right)(10)$ (1) and 0 s.

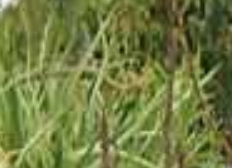

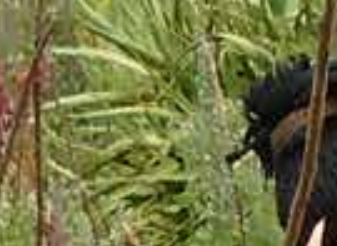

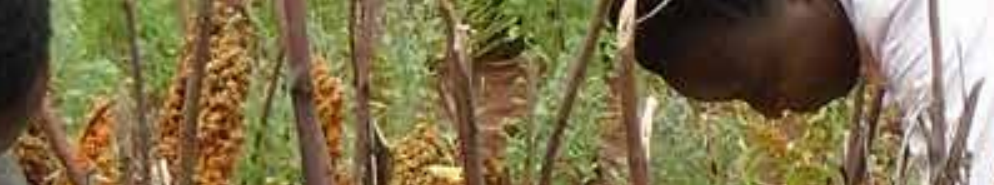
(a)

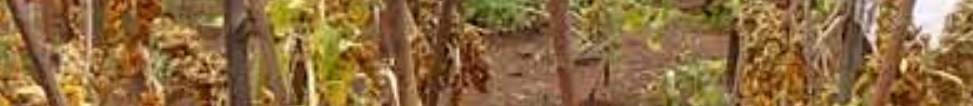
1. 25: 450 .

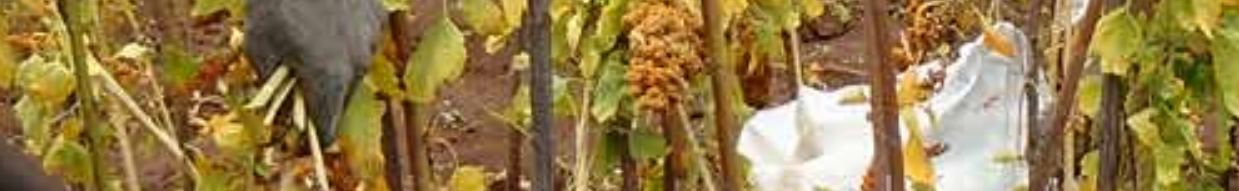

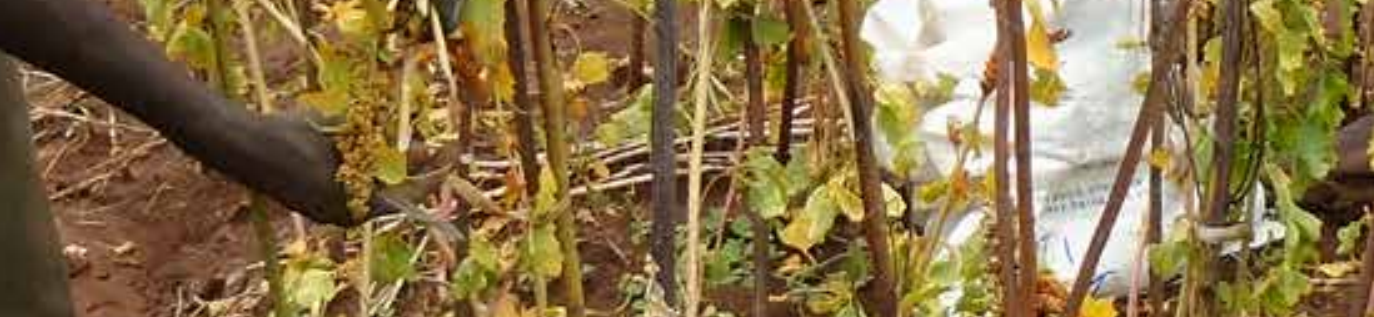

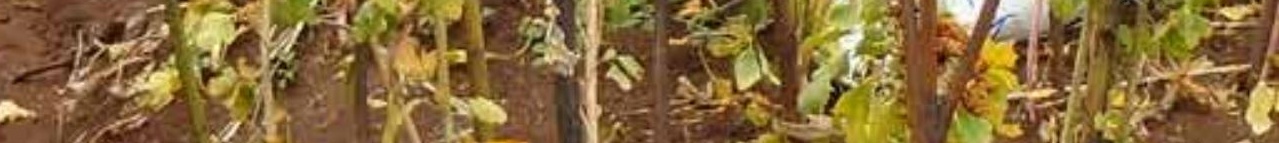

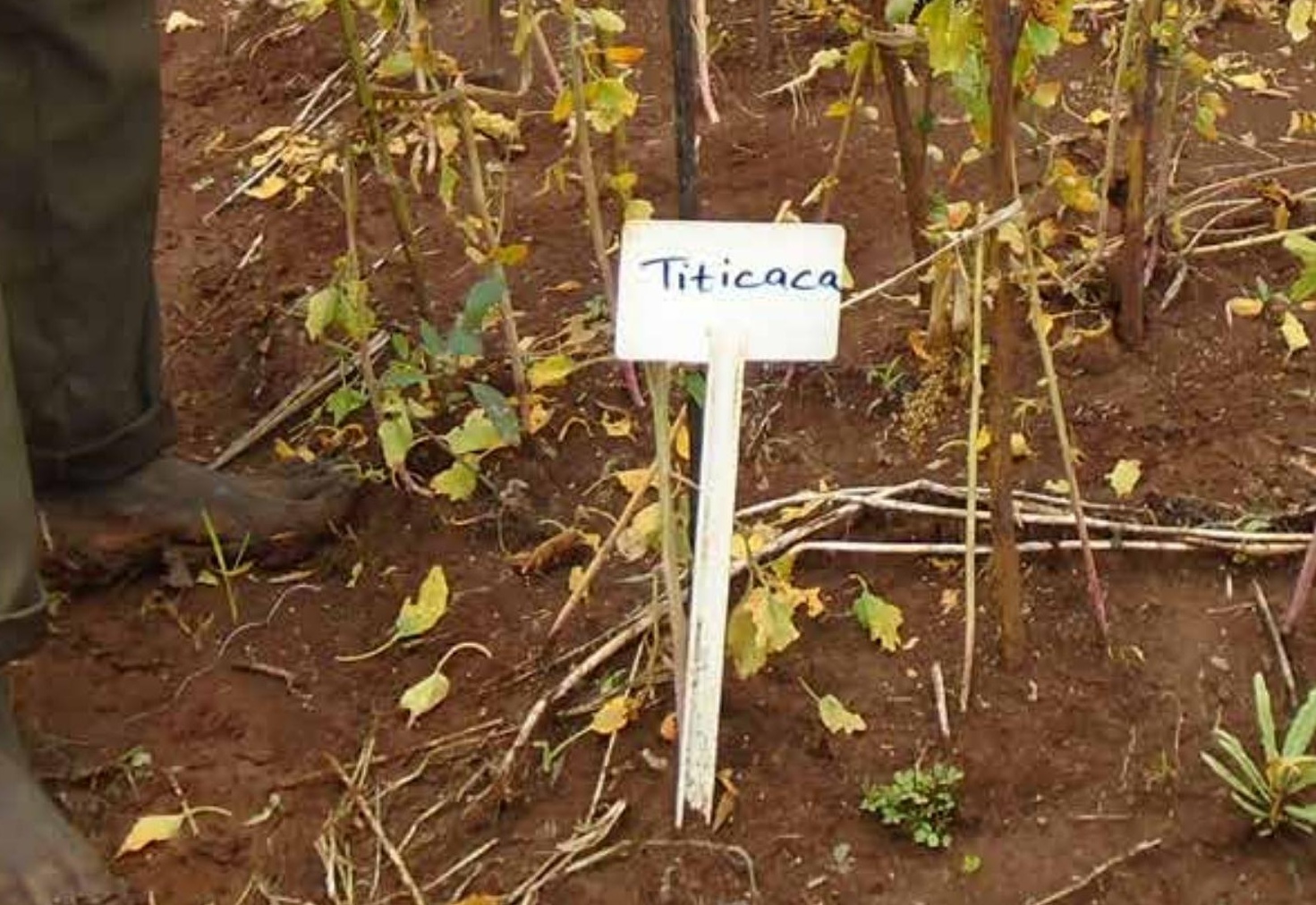
Titicaca 


\section{FAO subregional approach to introduce quinoa to Africa}

FAO is actively involved in promoting and evaluating the cultivation of quinoa outside native quinoagrowing regions with the aim of strengthening food and nutrition security (Bazile et al., 2016).

FAO initiated and funded a Technical Cooperation Programme (TCP) project titled "Technical assistance for the strengthening of the food system of quinoa" (TCP/SFE/3406) to support the institutional capacities of the beneficiary countries in the production, evaluation, management, utilization and marketing of quinoa under diverse farming systems and agro-ecological regions available in the participating countries (Djibouti, Ethiopia, Kenya, Somalia, South Sudan, Uganda and Zambia). This was envisaged to be a two-year (January 2014 -December 2015) project with expected outputs that included:

i) Potential quinoa genotypes and ecotypes selected for screening through site matching based on the comparison of the ecological conditions between the sources and the target countries;

ii) Quinoa genotypes and ecotypes screened for introduction; field testing and selection of superior genotypes based on adaptability and suitability for the participating countries;

iii) Capacities of partners' technical staff and stakeholders (among them selected farmers) strengthened in quinoa pre-production and post-production knowledge; and

iv) Information exchange, knowledge management and enhanced learning.

\subsection{Evaluation and experimentation}

\subsubsection{Countries and objectives}

The FAO, through its Subregional Office for Eastern Africa (SFE) in Addis Ababa, introduced 10 varieties to seven countries (see Table 6) in Eastern and Southern Africa, namely Djibouti, Ethiopia, Kenya, Somalia, South Sudan, Uganda and Zambia. Additional varieties from past initiatives were included in the trials in Ethiopia (one) and Kenya (four). Pilot experimental studies to determine the potential of quinoa to grow in the varied environments of the eastern and southern Africa region became necessary before extensive agronomic trials and utilization studies could be advanced. With coordination of the FAO SFE and CIAT regional offices (in Rwanda and Uganda), a regional network was established as a formal collaboration mechanism for quinoa development in the region. Membership comprised the seven countries that participated in the TCP project. The aim of the project was to evaluate adaptability and nutrient properties of a selected set of quinoa genotypes. Specific objectives were to:

i) Identify superior genotypes among the test genotypes and evaluate the influence of the environment on the performance of the varieties;

ii) Characterize the quinoa genotypes and increase the capacity to handle and evaluate quinoa in the national research systems;

iii) Identify major constraint(s) to quinoa productivity in the seven countries;

iv) Initiate the proposed promotional strategies for quinoa and popularize the crop; and

v) Identify superior nutrient properties of quinoa among the test genotypes and evaluate the influence of the environment on these properties.

\subsubsection{Preparation for pilot trials}

As quinoa is a new crop to the continent of Africa, many scientists working in government and agricultural research institutions are not familiar with the crop let alone its agronomic practices. 
Thus, prior to implementing the trials, FAO organized a one-week training workshop (in December 2014) facilitated by LUANAR to introduce the quinoa crop to scientists and researchers from the participating countries. The workshop provided training on field experimentation, production, postharvest management and utilization of quinoa. A research protocol was presented to guide the quinoa adaptability experiments in the participating countries. Participants developed experimental protocols and strategies for the promotion of quinoa in their specific countries. A quinoa research network for the Eastern and Southern Africa region was created to serve as a platform for sharing experiences throughout the experimentation period and beyond. FAO and CIAT-PABRA facilitated the acquisition of quinoa germplasm (Table 6) from Peru (Andean region) and Malawi, where several varieties had been introduced in 2012. A year after implementation of the pilot trials a workshop was organized for the participating scientists to share their results (where completed) and experiences and to chart the way forward for quinoa research in the region.

\subsubsection{Implementing institutions in participating countries}

The trials were implemented by the governments' agricultural research institutions - the National Agricultural Research System (NARS), which included the Centre d'Etude et de Recherche de Djibouti (CERD); Ethiopian Institute of Agricultural Research (EIAR) in Ethiopia; Kenya Agricultural \& Livestock Research Organization (KARLO) and FAO Kenya; FAO Somalia and the Somalia Ministry of Agriculture; FAO South Sudan and the South Sudan Ministry of Agriculture and Forestry; the Ministry of Agriculture, Animal Industry and Fisheries (MAAIF) and National Crops Resources Research Institute (NaCRRI) in Uganda; and the Zambia Agriculture Research Institute (ZARI). The International Center for Tropical Agriculture (CIAT) in Uganda and Rwanda served as the international research coordinator based on their previous experience in a regional common bean programme (PABRA), while the FAO Eastern Africa Subregional Office (FAOSFE) provided the technical and administrative lead.

\subsubsection{Evaluation trials - materials and methods}

\subsubsection{Sites}

Research teams from participating countries selected sites with varied environmental conditions (or agro-ecological zones) for the adaptability studies in their countries through consultations with national stakeholders. A total of 23 sites were selected for the experiments. Ethiopia had four sites, Kenya six, South Sudan two, Somalia one, Uganda six and Zambia four. Djibouti did not establish a trial site during the project period (due to challenges the team faced which will be discussed later) and therefore no quinoa data were considered for Djibouti in this paper. Table 6 presents sites that were selected in each country with environmental characteristics that prevailed during the trial period.

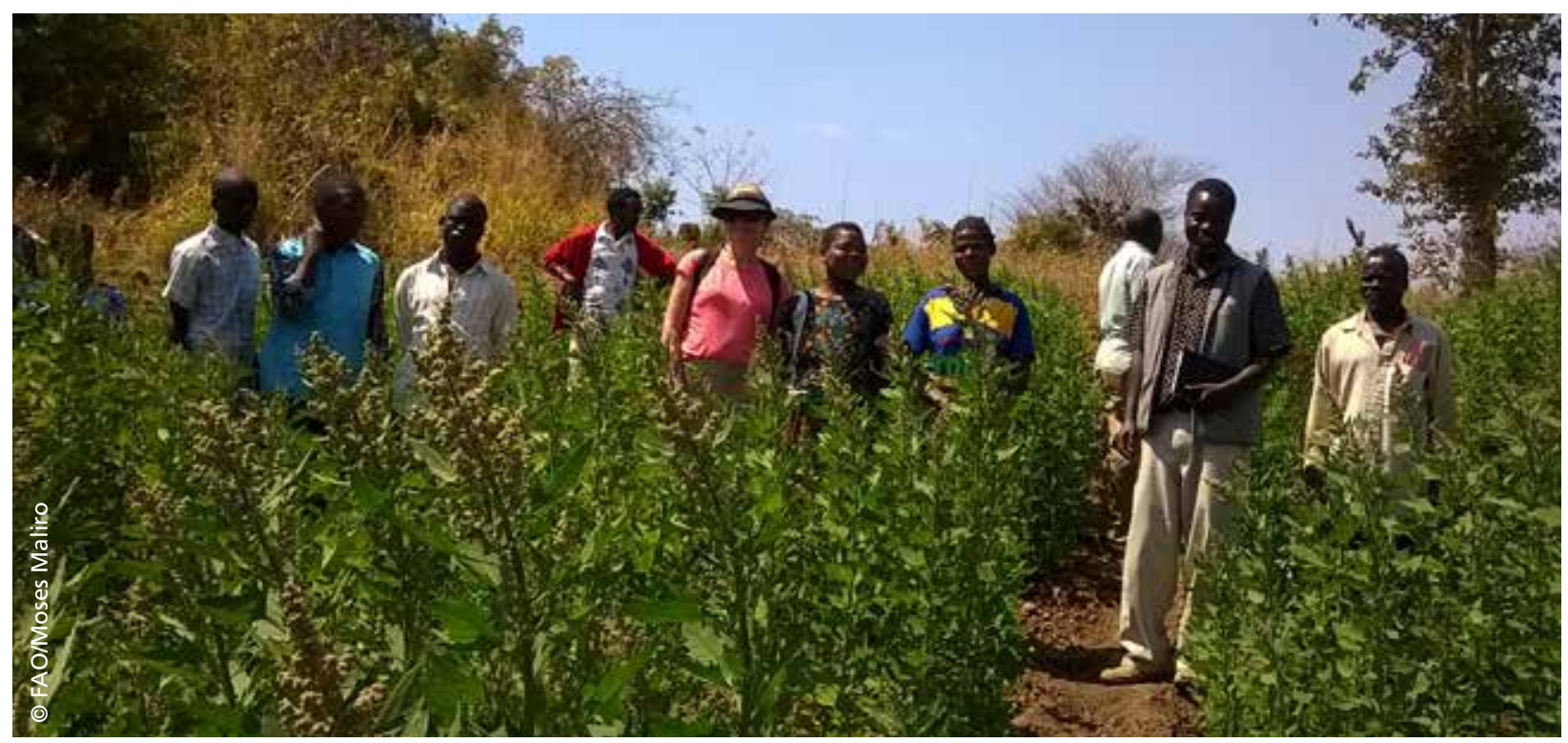


Table 6: List and characteristics of 23 experimental sites in Eastern Africa where quinoa adaptability studies were conducted in $\mathbf{2 0 1 5}$

\begin{tabular}{|c|c|c|c|c|c|c|c|c|}
\hline \multirow[t]{2}{*}{ Country } & \multirow[t]{2}{*}{ Trial site } & \multirow{2}{*}{$\begin{array}{l}\text { Mean } \\
\text { altitude } \\
\text { (m) }\end{array}$} & \multirow[t]{2}{*}{\begin{tabular}{|l} 
Rainfall \\
$(\mathrm{mm})$
\end{tabular}} & \multirow[t]{2}{*}{$\begin{array}{l}\text { Tempera- } \\
\text { ture }\left({ }^{\circ} \mathrm{C}\right)\end{array}$} & \multicolumn{2}{|c|}{ GPS position } & \multirow{2}{*}{$\begin{array}{l}\text { Plan- } \\
\text { ting/ } \\
\text { sowing } \\
\text { date } \\
(\mathrm{d} / \mathrm{m}) \\
\end{array}$} & \multirow[t]{2}{*}{ Irrigation } \\
\hline & & & & & Latitude (o) & Longitude(o) & & \\
\hline Djibouti & Not identified & & & & & & & \\
\hline \multirow[t]{5}{*}{ Ethiopia } & Melkassa & $1550(\mathrm{H})$ & 928 & $12.6-28.5$ & $8^{\circ} 24^{\prime} \mathrm{N}$ & $39^{\circ} 21^{\prime} \mathrm{E}$ & & Rainfed \\
\hline & Ziway & $1575(\mathrm{H})$ & 728 & $12.9-29.8$ & $8^{\circ} 20^{\prime} \mathrm{N}$ & $39^{\circ} \mathrm{E}$ & & Rainfed \\
\hline & ArsiNegele & & & & & & & Rainfed \\
\hline & Haramaya & $1980(\mathrm{H})$ & 800 & $8.25-25.4$ & $9^{\circ} 26^{\prime} \mathrm{N}$ & $42^{\circ} 3^{\prime} \mathrm{E}$ & & Rainfed \\
\hline & Kulumsa & $2200(\mathrm{H})$ & 820 & $10.5-22.8$ & $8^{\circ} 1^{\prime} 10^{\prime \prime} \mathrm{N}$ & $39^{\circ} 9^{\prime} 11^{\prime \prime} \mathrm{E}$ & & Rainfed \\
\hline \multirow[t]{6}{*}{ Kenya } & Marimba & $2155(\mathrm{H})$ & $1700-2600$ & $14.9-17.4$ & S 00.03739 & E $037.566119^{\circ}$ & $14 / 05$ & $\begin{array}{l}\text { Supple- } \\
\text { mental }\end{array}$ \\
\hline & Embu & $1511(\mathrm{H})$ & $1200-1400$ & $18.9-20.1$ & S $00.50533^{\circ}$ & E 037.45852 & $31 / 03$ & $\begin{array}{l}\text { Supple- } \\
\text { mental }\end{array}$ \\
\hline & *Koibatek & $1965(\mathrm{H})$ & $900-1100$ & $16-26$ & N 000030009' & E0350460784o & & Rainfed \\
\hline & Kithimu & $1422(\mathrm{M})$ & 900-1000 & $19.6-20.7$ & S $00.50257^{\circ}$ & E $037.53354^{\circ}$ & $6 / 10$ & Rainfed \\
\hline & Karuangi & $1292(\mathrm{M})$ & $1200-1340$ & $20.4-20.9$ & S $00.56884^{\circ}$ & E 037.43617 & $23 / 09$ & Rainfed \\
\hline & \begin{tabular}{|l|} 
Mitunguu/ \\
Tunyai \\
\end{tabular} & $964(\mathrm{~L})$ & $820-920$ & $21-23.5$ & S $00.10185^{\circ}$ & E $037.80373^{\circ}$ & $14 / 05$ & Rainfed \\
\hline \multirow{2}{*}{$\begin{array}{l}\text { South } \\
\text { Sudan }\end{array}$} & $\begin{array}{l}\text { Palotaka E. } \\
\text { Equatorial/Yei }\end{array}$ & $433(\mathrm{~L})$ & 1500 & & & & & Rainfed \\
\hline & Akog site-Wau & $831(\mathrm{~L})$ & 2000 & & & & & Rainfed \\
\hline Somalia & Dollow & $116(\mathrm{~L})$ & $0-1.8$ & $25-33.9$ & $4^{\circ} 9^{\prime} 59^{\prime \prime} \mathrm{N}$ & $\mathrm{E} 42^{\circ} 4^{\prime} 43^{\prime \prime} \mathrm{E}$ & $9 / 11$ & $\begin{array}{l}\text { Irrigated } \\
\text { (supll) }\end{array}$ \\
\hline \multirow[t]{6}{*}{ Uganda } & Namulonge & $1180(\mathrm{M})$ & & & & & & Rainfed \\
\hline & Buginyanya & $1800(\mathrm{H})$ & & & & & $9 / 04$ & Rainfed \\
\hline & Kawanda & $1200(\mathrm{M})$ & & $17.1-29.8$ & N000 2413.3 & E032'02.5 & & Rainfed \\
\hline & Serere & $1128(\mathrm{M})$ & & & \begin{tabular}{|l|} 
N1o31 \\
\end{tabular} & E33027 & $2 / 10$ & Rainfed \\
\hline & Mbarara & $1430(\mathrm{M})$ & & & & & & Rainfed \\
\hline & Nabuin & & & & & & & \\
\hline \multirow[t]{4}{*}{ Zambia } & $\begin{array}{l}\text { Mount } \\
\text { Makulu }\end{array}$ & 1213 & $800-1200$ & - & $15033^{\prime} \mathrm{S}$ & $028016^{\prime} \mathrm{E}$ & $\begin{array}{l}08 / 06 \\
24 / 06 \\
\end{array}$ & $\begin{array}{l}\text { Twice a } \\
\text { week }\end{array}$ \\
\hline & Mutanda & 1304 & & & $26011.700^{\prime \prime}$ & $12025.254^{\prime} \mathrm{S} ;$ & $04 / 06$ & $\begin{array}{l}3 \text { times a } \\
\text { week }\end{array}$ \\
\hline & Misamfu & 1536 & & $8.7-26.4$ & $31^{\circ} 08^{\prime} \mathrm{E}$ & $10^{\circ} 13^{\prime} \mathrm{S}$ & $2 / 06$ & $\begin{array}{l}\text { every } \\
\text { two days }\end{array}$ \\
\hline & Nanga & 934 & 531.9 & & & & $29 / 05$ & $\begin{array}{l}3 \text { times a } \\
\text { week }\end{array}$ \\
\hline
\end{tabular}

(H) = High altitude; $>1500$ m.a.s.l., $(M)$ = Mid altitude; $1000-1500$ m.a.s.l., (L) = Low altitude; <1 000 m.a.s.l.

\subsubsection{Germplasm}

Germplasm of genotypes for the studies was sourced from Peru (6) by FAO and others were supplied by LUANAR in Malawi but were originally sourced from Washington State University in the USA. Kenya (four genotypes) and Ethiopia (one genotype), who had some existing quinoa genotypes in their gene banks from previous introductions, added those to their list of germplasm for evaluation. An amaranth variety sourced from Uganda was added to the list as a check. Table 7 presents a list of the germplasm. CIAT coordinated the distribution of seeds of the genotypes to the implementing research institutions of the respective countries. 
Table 7: List of quinoa genotypes and genotypes supplied for the studies (FAO facilitated the
exchange of germplasm from Peru with SMTA signed)

\begin{tabular}{|l|l|l|l|l|l|l|l|c|c|c|}
\hline No. & Genotype & Origin & Source & DJ & ET & KE & SO & SS & UG & ZA \\
\hline 1 & Brightest Brilliant Rainbow & Oregon, US & Malawi & $\mathrm{x}$ & $\mathrm{x}$ & $\mathrm{x}$ & $\mathrm{x}$ & $\mathrm{x}$ & $\mathrm{x}$ & $\mathrm{x}$ \\
\hline 2 & Bio-Bio & Chile & Malawi & $\mathrm{x}$ & $\mathrm{x}$ & $\mathrm{x}$ & $\mathrm{x}$ & $\mathrm{x}$ & $\mathrm{x}$ & $\mathrm{x}$ \\
\hline 3 & Cherry Vanilla & Oregon, US & Malawi & $\mathrm{x}$ & $\mathrm{x}$ & $\mathrm{x}$ & $\mathrm{x}$ & $\mathrm{x}$ & $\mathrm{x}$ & $\mathrm{x}$ \\
\hline 4 & Multi-Hued & B C, Canada & Malawi & $\mathrm{x}$ & $\mathrm{x}$ & $\mathrm{x}$ & $\mathrm{x}$ & $\mathrm{x}$ & $\mathrm{x}$ & $\mathrm{x}$ \\
\hline 5 & Titicaca & Denmark & Malawi & $\mathrm{x}$ & $\mathrm{x}$ & $\mathrm{x}$ & $\mathrm{x}$ & $\mathrm{x}$ & $\mathrm{x}$ & $\mathrm{x}$ \\
\hline 6 & Blanca de Junín & Peru & FAO & $\mathrm{x}$ & $\mathrm{x}$ & $\mathrm{x}$ & $\mathrm{x}$ & $\mathrm{x}$ & $\mathrm{x}$ & $\mathrm{x}$ \\
\hline 7 & Amarilla Sacaca & Peru & FAO & $\mathrm{x}$ & $\mathrm{x}$ & $\mathrm{x}$ & $\mathrm{x}$ & $\mathrm{x}$ & $\mathrm{x}$ & $\mathrm{x}$ \\
\hline 8 & Amarilla Maranganí & Peru & FAO & $\mathrm{x}$ & $\mathrm{x}$ & $\mathrm{x}$ & $\mathrm{x}$ & $\mathrm{x}$ & $\mathrm{x}$ & $\mathrm{x}$ \\
\hline 9 & Salcedo INIA & Peru & FAO & $\mathrm{x}$ & $\mathrm{x}$ & $\mathrm{x}$ & $\mathrm{x}$ & $\mathrm{x}$ & $\mathrm{x}$ & $\mathrm{x}$ \\
\hline 10 & Kancolla & Peru & FAO & $\mathrm{x}$ & $\mathrm{x}$ & $\mathrm{x}$ & $\mathrm{x}$ & $\mathrm{x}$ & $\mathrm{x}$ & $\mathrm{x}$ \\
\hline 11 & Quinoa Red* & Not provided & Kenya & & & $\mathrm{x}$ & & & & \\
\hline 12 & Quinoa Tricolore* & Not provided & Kenya & & & $\mathrm{x}$ & & & & \\
\hline 13 & Quinoa Black* & Not provided & Kenya & & & $\mathrm{x}$ & & & & \\
\hline 14 & Quinoa White* & Not provided & Kenya & & & $\mathrm{x}$ & & & & \\
\hline 15 & QQ74 & Denmark & Malawi & & $\mathrm{x}$ & & & & & \\
\hline 16 & Salcedo-INTA-Puno-* & Peru & Ethiopia & & $\mathrm{x}$ & & & & & \\
\hline 17 & Amaranth & Uganda & Check & $\mathrm{x}$ & $\mathrm{x}$ & $\mathrm{x}$ & $\mathrm{x}$ & $\mathrm{x}$ & $\mathrm{x}$ & $\mathrm{x}$ \\
\hline
\end{tabular}

$\mathrm{DJ}=$ Djibouti, ET=Ethiopia, $\mathrm{KE}=$ Kenya, $\mathrm{SS}=$ South Sudan, $\mathrm{SO}=$ Somalia, $\mathrm{UG}=$ Uganda and $\mathrm{ZA}=\mathrm{Zambia}$; ${ }^{\star}$ Genotypes that participating countries sourced from their national gene banks.

\subsubsection{Sowing, planting and agronomic management of trials}

The trials were conducted in 2015, with sowing dates varying depending on the onset of rains in each country. The evaluation trials were conducted under rainfed conditions, except in Zambia where they were entirely under irrigated conditions. Where rainy seasons were too short to grow the quinoa to maturity, supplemental irrigation was applied, as in the case of two of four sites in Kenya (Marimba and $\mathrm{Embu}$ ) and in Somalia where trials were not completed. Of the six countries that conducted the trials, four (Ethiopia, Kenya, Uganda and Zambia) successfully completed a total of 14 trials, yielding data that were statistically analysed. The quinoa plant growth and grain yield results from these countries are therefore referred to in this paper. Of the 14 trials, six (Melkassa, ArsiNegele, Ziway, Misamfu, Nabuin and Buginyanya) are in the high-altitude zones (>1 500 m.a.s.l.), six (Embu, Karuangi, Namulonge, Kawanda, Mount Makulu and Mutanda) are in mid-altitude zones (1 $000-$ 1500 m.a.s.l.) and two (Mutanda and Mitunguu) in the low-altitude zones (<1 000 m.a.s.l.).

\subsubsection{Experimental protocol}

Trials in the participating countries followed a protocol that was developed at the initial stage of the project. Each country set up the experiments at the selected sites with the same experimental design. An exception was the number of genotypes - Kenya had an extra four varieties and Ethiopia an extra two added to their list in their evaluation (Table 7), which they sourced on their own or already had in their seed banks.

All trial experiments were laid out in a randomized complete block design (RCBD) with three replications and plot sizes of $2 \mathrm{~m} \times 2 \mathrm{~m}$ (five row plots spaced at $50 \mathrm{~cm}$ ). Five grammes $(\mathrm{gm})$ of seed mixed with $5 \mathrm{gm}$ of sand (1:1) were sown per plot using the drilling planting method in all sites. Two weeks after germination, plants were thinned to achieve a spacing of $50 \mathrm{~cm}$ between rows $\mathrm{x} 10 \mathrm{~cm}$ between plants (a total of 100 plants). A net plot comprised three centre rows per plot and resulted in approximately 60 plants. Spacing between plots was $0.50-1 \mathrm{~m}$ and $1-1.5 \mathrm{~m}$ between replicates. 
The trials were planted at different times that depended on climatic conditions and environmental, technical, institutional or logistical challenges faced in each country. The earliest planting was in March 2015 in Kenya and Uganda and the latest in October and November 2015 in Somalia and Sudan respectively (Table 6).

\subsubsection{Soil nutrient status}

Soil sampling and analysis of the experimental plots in all trial sites were conducted for $\mathrm{pH}$, texture and major mineral content (N, P, K). The major nutrients' status results guided fertilizer application rates in Somalia and Zambia to adjust to application rates used in quinoa where it is traditionally cultivated. In most of the sites, N:P:K (17:17:17) fertilizer was applied, while at some sites CAN was used for top dressing. Soil analysis was conducted at in-country laboratories, except for South Sudan whose samples were analysed at NARL-Uganda and Somalia whose samples were analysed at KARLO-Kenya (Table 8).

Soils of the Somalian site were very alkaline $(\mathrm{pH}=8.15)$ and although quinoa can do well in soils of up to $\mathrm{pH}=8.5$, soils in the experimental plot were amended with ammonium sulphate (AS). In general, quinoa does best in soils with a $\mathrm{pH}$ range of 6.0-8.5, but it is cultivated even in acidic and alkaline soils. In addition, quinoa thrives in well-drained fertile soils (Espindola, 1986), especially clay-loam soils with good nutrient content and drainage, however some quinoa genotypes are well adapted to extreme soil conditions (Mujica, 2009).

The nutrient status of all the sites fell into a very low category for nutrient ( $\mathrm{P} \& \mathrm{~K}$ based on Mehlich 3 extractable nutrients) availability that justified application of inorganic fertilizers.

\subsubsection{Data collection and analysis}

Trial management practices were noted for each experiment, that included sowing date, frequency and quantity of irrigation, timing, amount, distribution, placement and type of fertilizer and harvesting date. Performance of the different genotypes was determined by data collection that included number of days to emergence, stand count at harvest, plant height $(\mathrm{cm})$, flowering date at 50 percent (DF), maturity date at 90 percent (DPM), days from sowing to flowering, days from sowing to maturity, panicle length, branching architecture, 1000 seeds weight (g) and determined seed yield. Incidences of pests and diseases were also noted but scores were not done due to lack of expertise in the research teams.

Table 8: Soil characteristics of some of the experimental sites

\begin{tabular}{|l|l|c|c|c|c|}
\hline \multirow{2}{*}{ Country } & \multirow{2}{*}{ Trial sites } & \multicolumn{4}{|c|}{ Soil characteristics } \\
\cline { 3 - 6 } & & PH & OM (\%) & N (\%) & P (ppm) \\
\hline \multirow{4}{*}{ Uganda } & NACRRI & 4.65 & $6.2-9$ & $0.3-0.4$ & $4-30$ \\
\cline { 2 - 6 } & BugiZARDI & 4.7 & $9-9.2$ & 0.4 & 3.1 \\
\cline { 2 - 6 } & NARL & 4.95 & $6.2-7.4$ & $0.3-0.35$ & $2.1-15.5$ \\
\hline \multirow{5}{*}{ Kenya } & Marimba & 5.28 & $3.35^{*}$ & 0.35 & 40 \\
\cline { 2 - 6 } & Embu & 5.24 & $1.60^{*}$ & 0.14 & 30 \\
\cline { 2 - 6 } & Mitunguu/Tunyai & 7.08 & $1.09^{*}$ & 0.14 & 30 \\
\cline { 2 - 6 } & Kithimu & 5.01 & $1.75^{*}$ & 0.16 & 30 \\
\cline { 2 - 6 } & Karuangi & 5.28 & $1.21^{*}$ & 0.16 & 30 \\
\hline \multirow{5}{*}{ South Sudan } & Palotaka E. Equatoria & 6.12 & 7.01 & 0.33 & 8.01 \\
\cline { 2 - 6 } & Akog site-Wau & 6.5 & 5.17 & 0.26 & 17.5 \\
\hline Somalia & Dollow & 8.12 & 1.43 & 0.14 & 14 \\
\hline
\end{tabular}

*Total carbon 
The data from Ethiopia, Kenya, Uganda and Zambia (representing 14 sites) were made available to CIAT for analysis. Six parameters were analysed - days to 50 percent flowering (DF), days to physiological maturity (DPM), plant height (PH), panicle length (PL), seed yield/plot and yield/ha (YDHA). Analysis was done using the Breeding View tool of the integrated breeding platform (IBP Breeding Management System Version 3.0.8 of 2015). Single site analysis and G x E was analysed through the Finlay Wilkinson model (FW), additive main effect and multiplicative interaction (AMMI) model analysis and genotype main effects and genotype $\times$ environment interaction effects (GGE) model (Gauch, 2006). Stability and cultivar superiority were estimated by means of these models. The GGE bi-plots grouped the 14 sites (environments) into mega environments (described in section 4.2.5.3) where similar interventions can be promoted based on the data generated (Mukankusi et al., 2016).

\subsection{Agronomic performance of quinoa in the 14 environments}

\subsubsection{Germination and crop establishment}

Results on germination success of crop establishment varied across sites. Some genotypes completely failed to germinate in some sites. In Uganda, the trial at NaCRRI (Namulonge) was re-sowed but on a different field where the genotypes germinated and had a better establishment. The failure to germinate in the first field was attributed to low soil-fertility levels. Addition of organic matter to the replanted trial field resulted in better establishment. There was also poor establishment of trials at Kenya's Marimba site that was attributed to high altitude (2 155 m.a.s.l.) similar to Uganda's Namulonge site. The first sowing at the Kenya Mitunguu site resulted in poor germination but when resowed the crop was much better than the first sowing. Poor germination was also experienced in Ethiopia and Somalia in four genotypes that failed to germinate. This was attributed to poor seed quality. In Somalia the failure of the four genotypes, Amarilla Maranganí, Amarilla Sacaca, Kancolla and Blanca de Junín (Table 6) was attributed to seed quality, especially the age of the seed that arrived in Somalia more than eight months after it was shipped from Peru. The same was observed in other trials of FAO-TCPs in other regions. The seed germination tests also showed that seed supplied by LUANAR (Malawi) of about 12 months' shelf life had relatively higher germination rates (Table 9), strongly suggesting that age of the seed and possibly other factors affected its viability. While the shipping conditions (high temperatures and moisture) might have accelerated the deterioration of the seed shipped to Somalia, drought and heat conditions experienced in the Somalia sites might also have contributed to the failure. In general, the varieties that originated from Peru either failed to germinate or had a very low germination rate compared with those sourced from Malawi (although they were different genotypes).

Quinoa establishment under rainfed conditions in Malawi showed that seed sowing that is followed by heavy rainstorms is often poor, attributed to seed being washed away by runoff and mechanical damage or battering of the germinating seed by raindrops. At times it may also be that very high moisture smothers the seedlings at their early stages. Mulching of beds sown with quinoa seed has been proposed to improve the establishment of seedlings especially under rainfed conditions (Maliro and Guwela, 2015). Mulching has been observed to reduce or prevent seed washing down the slope as well as mechanical damage of the tender seedlings. However, to prevent the seedlings from becoming spindly, the mulch should not be left too long. There is a need for more studies on the quality of quinoa seed to increase our understanding of recommended seed quality factors, and field and environmental conditions for good establishment of quinoa. 
Table 9: Seed quality test results for quinoa genotypes sampled from Somalia batches received from Peru (KEPHIS laboratory)

\begin{tabular}{|l|c|c|}
\hline Sample ID & Purity \% & Germination \% \\
\hline Amarilla Maranganí & 99.5 & 0 \\
\hline Multi-Hued & 99.4 & 27 \\
\hline Blanca de Junín & 99.5 & 0 \\
\hline Amarilla Sacaca & 99.2 & 0 \\
\hline Kancolla & 99.73 & 0 \\
\hline Titicaca & 99.3 & 33 \\
\hline Salcedo INIA & 97.9 & 7 \\
\hline Bio-Bio & 99.6 & 26 \\
\hline Brightest Brilliant Rainbow & 99.6 & 20 \\
\hline Cherry Vanilla & 99.6 & 25 \\
\hline Amaranth Golden & 99.9 & 38 \\
\hline
\end{tabular}

NB: A germination rate of 60 to 100 percent would be regarded as good, depending on seed storage conditions and prevailing temperatures after sowing (Strenske et al., 2017, Moreno et al., 2017, de Jesus Souza et al., 2017)

Plants of some of the genotypes exhibited variation in morphological traits, suggesting that there might have been seed mixing up or their landrace status prior to seed shipping. For instance, plants with yellow- and pink-coloured stems were observed in the experimental plots of the variety Titicaca while Brightest Brilliant Rainbow (BBR) had some plants with intermediate panicle shapes and others with a glomerulate shape. Yellow and orange panicles were observed in Multi-Hued and Titicaca and green and purple panicles were observed within the variety Bio-Bio at NARL-Kawanda. In some cases, rouging out of the off-types was done while in other cases it was not done. On the other hand, the seed quality results from KEPHIS for the Somalia samples showed greater than 99 percent purity (Table 9) for all the test varieties. Quinoa is a self-pollinated crop with up to 10 percent crosspollination (Jacobsen, 1993), which could explain the observation of off-types that probably arose from cross-pollination and not only as a result of seed mixtures. These observations call for studies to examine if cross-pollination is accelerated beyond the 10 percent by other environmental factors. Meanwhile seed multiplication needs to be done in distant isolation plots for each variety with at least 100 metres that is normally applied in cross-pollinated crops such as maize.

\subsubsection{Flowering, maturity, panicle length and plant height}

Eleven genotypes were successfully established and evaluated in the 14 environments (Figure 6) that included three in Ethiopia (ArsiNegele, Melkassa and Ziway), three in Kenya (Embu, Tunyai and Karuangi), four in Uganda (Kawanda, Namulonge, Buginyanya and Nabuin) and four in Zambia (Misamfu, Mount Makulu, Mutanda and Nanga). The quinoa genotypes showed significant differences in their performance across the environments in duration from sowing to flower (DSF) and physiological maturity (DPM) (Table 10), plant height, panicle length (Table 11) and seed yield. There were also significant $(\mathrm{P}=0.05)$ in-country differences between varieties. Early flowering corresponded with early physiological maturity and likewise for late onset of flowering. 
Table 10: Variation in days from sowing to flowering (DSF) and days to physiological maturity (DPM) among 10 quinoa varieties in fourteen sites of Eastern and Southern African countries (s.d. = standard deviation, s.e.m. = standard error of mean)

\begin{tabular}{|c|c|c|c|c|c|c|c|}
\hline \multirow{2}{*}{\multicolumn{2}{|c|}{ Name of site }} & \multicolumn{3}{|c|}{ Days from sowing to flowering (DSF) } & \multicolumn{3}{|c|}{ Days to physiological maturity (DPM) } \\
\hline & & Mean \pm s.d. & s.e.m. & Variance $(\sigma)$ & Mean \pm s.d. & s.e.m. & Variance $(\sigma)$ \\
\hline$A$ & Misamfu & $42.32 \pm 2.039$ & 0.6146 & 4.156 & $113.7 \pm 17.42$ & 5.251 & 303.3 \\
\hline B & Mount Makulu & $40.94 \pm 3.371$ & 1.0163 & 11.363 & $91.6 \pm 2.11$ & 0.637 & 4.5 \\
\hline$C$ & Mutanda & $54.15 \pm 0.192$ & 0.0578 & 0.037 & $150.1 \pm 25.69$ & 7.744 & 659.7 \\
\hline $\mathrm{D}$ & Nanga & $41.94 \pm 2.185$ & 0.6587 & 4.773 & $116.8 \pm 3.08$ & 0.930 & 9.5 \\
\hline$E$ & Kawanda & $38.48 \pm 2.152$ & 0.6807 & 4.633 & $90.3 \pm 8.33$ & 2.635 & 69.4 \\
\hline$F$ & $\mathrm{NaCRRI}$ & $56.21 \pm 3.629$ & 1.1475 & 13.168 & - & - & - \\
\hline $\mathrm{G}$ & BugiZARDI & $54.49 \pm 2.430$ & 0.7327 & 5.905 & $113.9 \pm 6.591$ & 6.591 & 477.8 \\
\hline $\mathrm{H}$ & Nabuin & $32.78 \pm 1.586$ & 0.4782 & 2.516 & $71.9 \pm 1.136$ & 1.136 & 14.2 \\
\hline I & ArsiNegele & - & - & - & $92.2 \pm 3.596$ & 3.596 & 116.4 \\
\hline$J$ & Melkassa & - & - & - & $83.1 \pm 0.816$ & 0.816 & 5.3 \\
\hline K & Ziway & - & - & - & $91.2 \pm 2.201$ & 2.201 & 38.8 \\
\hline $\mathrm{L}$ & Embu & $44.18 \pm 1.848$ & 0.5571 & 3.414 & $110.0 \pm 8.119$ & 8.119 & 725.1 \\
\hline$M$ & Tunyai & $33.45 \pm 4.132$ & 1.2458 & 17.073 & $97.9 \pm 4.115$ & 4.115 & 186.3 \\
\hline $\mathrm{N}$ & Karuangi & $30.45 \pm 4.569$ & 1.3775 & 20.873 & $98.2 \pm 3.511$ & 3.511 & 110.9 \\
\hline
\end{tabular}

The quinoa genotypes matured the earliest at Nabuin (71.9 days), followed by Melkassa ( 81.3 days), Kawanda, Ziway, Mount Makulu, ArsiNegele, Tunyai and Karuangi, with the mean maturity period ranging from 90.3 to 98.2 days. The intermediate maturity period was 110 days in Embu, 113.7 days in Misamfu, 113.9 days in Burginyanya and 116.8 days in Nanga, while the genotypes at Mutanda took 150.1 days (the longest period) to mature. This variation in maturity period across the tested sites could be attributed to variation in temperatures that are greatly influenced by altitude and latitude. Sites in low altitudes would generally be warmer than those in high-altitude ecological areas. The influence of latitude is that ecological areas that are closer to the equator are warmer than those that are further away from the equator. The rate of biochemical reactions that have a direct effect on crop flowering mechanisms is generally faster as temperature increases (Fitter and Fitter, 2002; Kaesha, 2009). The sites where the quinoa matured earlier are located in ecological areas that are closer to the equator and temperatures were expected to be higher except where they are modified by high altitude and physiological maturity was moderately delayed. On the other hand, maturity of crops can also be accelerated by short rainfall duration whereby early cessation of rains induces early senescence of the plants before real physiological maturity. However, no such case was reported in the current trials, hence the variation observed here can be attributed to temperature variations. The variation in maturity period across the varied sites shows that quinoa has plasticity to adjust to changing agroecological conditions (Olesen et al., 2012) that are often defined by temperature and rainfall.

\subsubsection{Panicle length and plant height}

The longest panicles were observed in Embu $(107.5 \mathrm{~cm})$ and the shortest in Ziway $(8.9 \mathrm{~cm})($ Table 11). The greatest variation in panicle length was observed in Embu (ranging between $62.5-84.6 \mathrm{~cm}$ ) and the least variation in ArsiNegele (Table 11). With respect to plant height, significant differences $(\mathrm{P}=0.001)$ were observed among the different genotypes and among the test sites. Once again variation was highest in Embu $(101-183 \mathrm{~cm})$, followed by Nanga $(89-154 \mathrm{~cm})$. The tallest quinoa plants $(183$ $\mathrm{cm}$ ) were observed in Embu, Kenya and the shortest $(45.8 \mathrm{~cm})$ in Buginyanya, Uganda. In Ethiopia, Kenya and Zambia, due to the large plant heights observed, staking was done to avoid lodging. In Zambia, strings supported by stakes were tied around the plot and in Ethiopia and Kenya, stakes were inserted in the ground per two to three plants. 
Table 11: Variation in panicle length $(\mathrm{cm})$ and plant height $(\mathrm{cm})$ in 10 quinoa genotypes in fourteen sites of Eastern and Southern African countries (s.d. = standard deviation, s.e.m. = standard error of mean)

\begin{tabular}{|l|l|c|c|c|c|c|c|}
\hline \multirow{2}{*}{ Name of site } & \multicolumn{3}{c|}{ Panicle length $(\mathrm{cm})$} & \multicolumn{3}{c|}{ Plant height (cm) } \\
\cline { 3 - 9 } & Mean \pm s.d. & s.e.m. & Variance $(\sigma)$ & Mean \pm s.d. & s.e.m. & Variance $(\sigma)$ \\
\hline A & Misamfu & $25.67 \pm 5.786$ & 1.745 & 33.48 & $85.42 \pm 21.57$ & 6.504 & 465.3 \\
\hline B & Mount Makulu & $29.68 \pm 7.171$ & 2.162 & 51.42 & $103.10 \pm 10.24$ & 3.088 & 104.9 \\
\hline C & Mutanda & $16.51 \pm 0.940$ & 0.283 & 0.88 & $89.45 \pm 13.08$ & 3.945 & 171.2 \\
\hline D & Nanga & $39.87 \pm 7.345$ & 2.215 & 53.95 & $120.65 \pm 23.66$ & 7.134 & 559.8 \\
\hline E & Kawanda & $67.23 \pm 2.493$ & 0.788 & 6.21 & - & - & - \\
\hline F & NaCRRI & $35.10 \pm 3.408$ & 1.028 & 11.61 & $116.11 \pm 10.01$ & 3.017 & 100.1 \\
\hline G & BugiZARDI & $16.52 \pm 1.269$ & 0.383 & 1.61 & $39.83 \pm 4.02$ & 1.211 & 16.1 \\
\hline H & Nabuin & $28.21 \pm 3.874$ & 1.168 & 15.01 & $76.80 \pm 14.63$ & 4.411 & 214.0 \\
\hline I & ArsiNegele & $17.81 \pm 2.774$ & 0.836 & 7.70 & $67.66 \pm 11.93$ & 3.596 & 142.2 \\
\hline J & Melkassa & $19.47 \pm 5.636$ & 1.782 & 31.77 & $85.02 \pm 17.11$ & 5.411 & 292.8 \\
\hline K & Ziway & $14.24 \pm 4.871$ & 1.722 & 23.73 & $62.91 \pm 10.37$ & 3.667 & 107.5 \\
\hline L & Embu & $84.68 \pm 14.523$ & 4.379 & 210.91 & $142.91 \pm 27.52$ & 8.297 & 757.2 \\
\hline M & Tunyai & $31.82 \pm 10.381$ & 3.130 & 107.76 & $108.82 \pm 19.64$ & 5.922 & 385.8 \\
\hline N & Karuangi & $31.95 \pm 10.162$ & 3.064 & 103.27 & $118.24 \pm 22.10$ & 6.664 & 488.4 \\
\hline
\end{tabular}

\subsubsection{Grain yield performance}

The grain yield from four countries - Ethiopia, Kenya, Uganda and Zambia - is presented in Table 12. The quinoa grain yield was most variable at Melkassa, ranging from $40 \mathrm{~kg} / \mathrm{ha}$ to $4411 \mathrm{~kg} / \mathrm{ha}$, while Nanga environment had the least variable yields with a range of 1184 to $1301 \mathrm{~kg} / \mathrm{ha}$. The highest grain yield (4 $468 \mathrm{~kg} / \mathrm{ha}$ ) was reported in Embu and the lowest (40 kg/ha) in Melkassa.

The grain yields realized in these environments were as high as those reported in the environments of South America, while yields in some environments of Kenya were higher. High quinoa yields within the range of 4 to $9 \mathrm{t} /$ ha have been reported in several trials within and outside the Andean region, i.e. 6.07 t/ha in La Paz, Bolivia, 6.1 t/ha in Chile, 9.33 t/ha in Neuva, Mexico of USA (Bhargava and Ohri, 2015) and Turkey (Yazar et al., 2015). These results show that under fertile and optimal conditions (such as water, temperature and radiation), high quinoa grain yields can be achieved. High yields of 6 to $9 \mathrm{t} /$ ha may add to the attractiveness of the crop in regions of the world where maize, or wheat and rice are staple grains.

Table 12: Variation in yield (kg/ha) in 10 quinoa genotypes (listed in Table 9) in fourteen sites of Eastern and Southern African countries (s.d. = standard deviation, s.e.m. = standard error of mean)

\begin{tabular}{|l|l|c|c|c|c|c|c|c|}
\hline \multicolumn{2}{|l|}{ Name of site } & Mean & Median & Min. & Max. & s.d. & s.e.m. & Variance (б) \\
\hline A & Misamfu & 1640 & 1437 & 1176.7 & 2364 & 411.2 & 124.0 & 169066 \\
\hline B & Mount Makulu & 1760 & 1435 & 765.7 & 2726 & 760.4 & 229.3 & 578146 \\
\hline C & Mutanda & 1345 & 1213 & 297.7 & 3011 & 715.1 & 215.6 & 511304 \\
\hline D & Nanga & 1236 & 1236 & 1183.6 & 1301 & 26.8 & 8.1 & 718 \\
\hline E & Kawanda & 368 & 319 & 155.4 & 974 & 237.0 & 74.9 & 56160 \\
\hline F & NaCRRI & 1850 & 1935 & 1134.7 & 2891 & 584.5 & 176.2 & 341627 \\
\hline G & BugiZARDI & 801 & 801 & 671.5 & 1033 & 105.0 & 31.7 & 11021 \\
\hline H & Nabuin & 2106 & 2106 & 1537.1 & 2684 & 327.0 & 98.6 & 106924 \\
\hline I & ArsiNegele & 1214 & 789 & 169.9 & 2928 & 1113.1 & 393.5 & 1238963 \\
\hline J & Melkassa & 1944 & 2134 & 40.0 & 4411 & 1411.9 & 499.2 & 1993540 \\
\hline K & Ziway & 642 & 195 & 40.4 & 3950 & 1340.9 & 474.1 & 1798116 \\
\hline
\end{tabular}




\begin{tabular}{|l|l|l|l|l|l|l|l|l|}
\hline \multicolumn{2}{|l|}{ Name of site } & Mean & Median & Min. & Max. & s.d. & s.e.m. & Variance $(\sigma)$ \\
\hline L & Embu & 3046 & 2805 & 1542.0 & 4468 & 924.6 & 278.8 & 854904 \\
\hline M & Tunyai & 1033 & 742 & 254.0 & 2052 & 597.3 & 180.1 & 356783 \\
\hline N & Karuangi & 1599 & 1276 & 898.0 & 2800 & 667.6 & 222.5 & 445756 \\
\hline
\end{tabular}

\subsubsection{Genotype by environment ( $\mathrm{G}$ x E) interaction}

A Finlay Wilkinson (FW) analysis of $\mathrm{G}$ x E of 11 genotypes across 14 environments showed significant $\mathrm{G} \times \mathrm{E}$ interactions for all traits except yield (Table 13). However, FW accounted for only 16.8, 23.23, 19.8, 13.9 and 10.5 percent of the G x E for DF, DPM, panicle length, plant height and yield (kg/ha) respectively. Mean days to flowering ranged between 41 (Bio-Bio and Brightest Brilliant Rainbow) and 44 days (Amarilla Sacaca) across the 14 environments. Days to physiological maturity ranged between 91 days (Titicaca) and 112 days (Blanca de Junín). The genotype Amarilla Maranganí had the longest panicles and Bio-Bio the shortest, while the genotype Amarilla Maranganí was the tallest and the shortest plants were from the genotypes Bio-Bio, Brightest Brilliant Rainbow and Cherry Vanilla. The highest yield was recorded by Titicaca (2 $022 \mathrm{~kg} / \mathrm{ha})$ and the lowest by Salcedo INIA across the 14 sites (Tables 15 and 16).

An additive main effect and multiplicative interaction (AMMI) analysis (Table 14) accounted for 7.95, 79.3, 78.6, 83.7 and 55 percent of the total variation for DF, DPM, panicle length, plant height and yield respectively. Both IPCA 1 and IPCA 2 were significant $(\mathrm{P}=0.05)$ for all the parameters measured, accounting for higher proportions of the variation: 63.4, 98, 99, 99 and 75 percent of the $G$ x E observed for DF, DPM, panicle length, plant height and yield respectively.

Table 13: Finlay Wilkinson analysis of variance for parameters of 11 quinoa genotypes among 14 environments

\begin{tabular}{|c|c|c|c|c|c|c|}
\hline \multirow{2}{*}{ Source of variation } & \multicolumn{2}{|r|}{ DF } & \multicolumn{2}{|r|}{ DPM } & \multicolumn{2}{|c|}{ Panicle length } \\
\hline & d.f. & s.s. & d.f. & s.s. & d.f. & s.s. \\
\hline Genotypes & 10 & 98.7354 & 10 & $6330.1263 * *$ & 10 & 1434.8603 ** \\
\hline Environments & 10 & 8702.869 ** & 12 & $48042.9335^{* *}$ & 13 & 55358.0721 ** \\
\hline Sensitivities & 10 & $129.4294^{*}$ & 10 & $4932.1581 * *$ & 10 & $1094.0642 * *$ \\
\hline Residual & 88 & 642.9321 & 99 & 16296.4285 & 115 & 4419.4834 \\
\hline \multirow[t]{2}{*}{ Total } & 118 & 9573.9659 & 131 & 75601.6464 & 148 & 62306.48 \\
\hline & \multicolumn{2}{|c|}{ Plant height } & \multicolumn{2}{|r|}{ YDHA } & & \\
\hline Genotypes & 10 & $7864.9305^{* *}$ & 10 & $12209765.96 * *$ & & \\
\hline Environments & 12 & $101416.7266 * *$ & 13 & 62008540.26 ** & & \\
\hline Sensitivities & 10 & 4199.4879* & 10 & $5405383.523 \mathrm{NS}$ & & \\
\hline Residual & 106 & 25970.6427 & 108 & 51397349.77 & & \\
\hline Total & 138 & 139451.7878 & 141 & 131021039.5 & & \\
\hline
\end{tabular}

Table 14: Additive main effects and multiplicative interaction (AMMI) model for 10 quinoa genotypes evaluated in 11 environments

\begin{tabular}{|l|c|c|c|c|c|c|c|c|c|c|}
\hline \multirow{2}{*}{ Source } & \multicolumn{2}{|c|}{ DF } & \multicolumn{2}{c|}{ DPM } & \multicolumn{2}{c|}{ Panicle length } & \multicolumn{2}{c|}{ Plant height } & \multicolumn{2}{c|}{ Yield (kg/ha) } \\
\cline { 2 - 12 } & d.f. & s.s. & d.f. & S.s. & d.f. & s.s. & d.f. & s.s. & d.f. & S.s. \\
\hline Genotypes & 10 & 89 & 10 & 60753 & 10 & 29439 & 10 & 1277539 & 10 & 16943406 \\
\hline Environments & 10 & $8939 * *$ & 12 & $100607 *$ & 13 & $57383^{*}$ & 12 & 1703134 & 13 & $95704515^{* *}$ \\
\hline Interactions & 100 & 780 & 120 & 616629 & 130 & 318769 & 120 & 15279908 & 130 & 139143073 \\
\hline IPCA 1 & 19 & $323 * *$ & 21 & $593897 * *$ & 22 & $313803 * *$ & 21 & $15255412 * *$ & 22 & $60392410 * *$ \\
\hline IPCA 2 & 17 & $172 * *$ & 19 & $10058 * *$ & 20 & $3120 * *$ & 19 & $12723^{* *}$ & 20 & $44086428 * *$ \\
\hline Residuals & 64 & 284 & 80 & 12673 & 88 & 1846 & 80 & 11773 & 88 & 34664235 \\
\hline
\end{tabular}


The AMMI showed that the environments of Mount Makulu, NaCRRI and Karuangi had the largest genetic differences with respect to DF, while the environment of Mutanda exhibited the least genetic variance variable. With respect to DPM, the environments of Embu, BugiZARDI and Mutanda exhibited the highest genetic differences. Regarding panicle length and plant height, the highest genetic differences occurred in Ziway. With respect to yield, the highest genetic differences were observed in ArsiNegele and Ziway. Environments exhibiting high genetic variances can be proposed as good test environments for the specific traits. For instance, environments that exhibit contrasting temperatures can be sites for selection of genotypes adapted to either warm or cold environments.

\subsubsection{Stability of genotype performance across environments}

Stability implies the ability to maintain consistent performance across different test environments. Based on AMMI and static stability, the genotype Salcedo INIA was the most stable for days to 50 percent flowering (DF) and Titicaca was the most unstable (Table 15). Similarly, with regard to DPM, Amaranth was the most stable and the genotype Titicaca the most unstable. Regarding panicle length, the genotype Titicaca was the most stable and Blanca de Junín the most unstable. With respect to plant height, the genotype Cherry Vanilla was the most stable and Amarilla Sacaca the most unstable; for YDHA, Amarilla Sacaca was the most unstable and Salcedo INIA the most stable. Based on Wricke's Ecovalence, Amaranth Gold and Amarilla Gold were the most stable with respect to yield and plant height, while the genotype Titicaca was the most unstable.

Based on yield performance, the genotypes Multi-Hued, Brightest Brilliant Rainbow, Titicaca and Bio-Bio were the best yielding genotypes in Zambia (Table 15), Amarilla Maranganí, Multi-Hued and Titicaca were the best performing across all sites in Uganda (Tables 15 and 16), while Multi-Hued, Amarilla Maranganí and Amarilla Sacaca performed the best across all the sites in Kenya (Tables 15 and 16).

\subsubsection{Cultivar superiority}

Cultivar superiority is defined as the distance mean square between the cultivar's response and the maximum response averaged over all locations (Lin and Binns, 1988). Since the maximum response is the upper boundary in each location, a small mean square indicates general superiority of the test cultivar. Brightest Brilliant Rainbow emerged as the most superior (stable and consistent) genotype with regard to days to 50 percent flowering as it was consistent in its good performance, i.e. shortest number of days to flowering across the 14 environments (Table 16). Bio-Bio had the most superior performance regarding DPM, i.e. shortest number of days to physiological maturity across the 14 environments. The genotype Amarilla Maranganí had consistent long panicles and tall plants across the environments, while the genotype Kancolla was the most superior in yield performance among the test environments.

\subsubsection{Grouping of environments and best performing varieties}

Based on yield performance, the 14 environments could be grouped into two mega-environments. The first mega-environment included ArsiNegele, Melkassa, Mount Makulu, Misamfu, Nanga, Namulonge, Kawanda, Karuangi and Tunyai. The second mega-environment included Misamfu, Nanga, NaCRRI, Kawanda, Karuangi, Embu, Tunyai and Ziway. There was an overlap between these environments with Embu and Tunyai being unique for environment 2 and ArsiNegele, Melkassa and Mount Makulu being unique for environment 1. Titicaca and Brightest Brilliant Rainbow were the leading genotypes (best performing) in mega-environment 1 and Amarilla Sacaca and Amarilla Maranganí were the leading genotypes in mega-environment 2.

This data set showed that altitude as a component of the environment did not play a major role in influencing genotype performance as high-, medium- and low-altitude environments were grouped together. Among the 14 environments, six were classified as high-altitude (>1500 m.a.s.l.) and included Melkassa and Ziway in Ethiopia, Embu and Marimba in Kenya, Buginyanya in Uganda and Misamfu in Zambia; six were classified as mid-altitude (1000-1 500 m.a.s.l.) and included Kithimu and Karuangi in Kenya, NARL-Kawanda and NaCRRI in Uganda, Mount Makulu and Mutanda in Zambia; and 

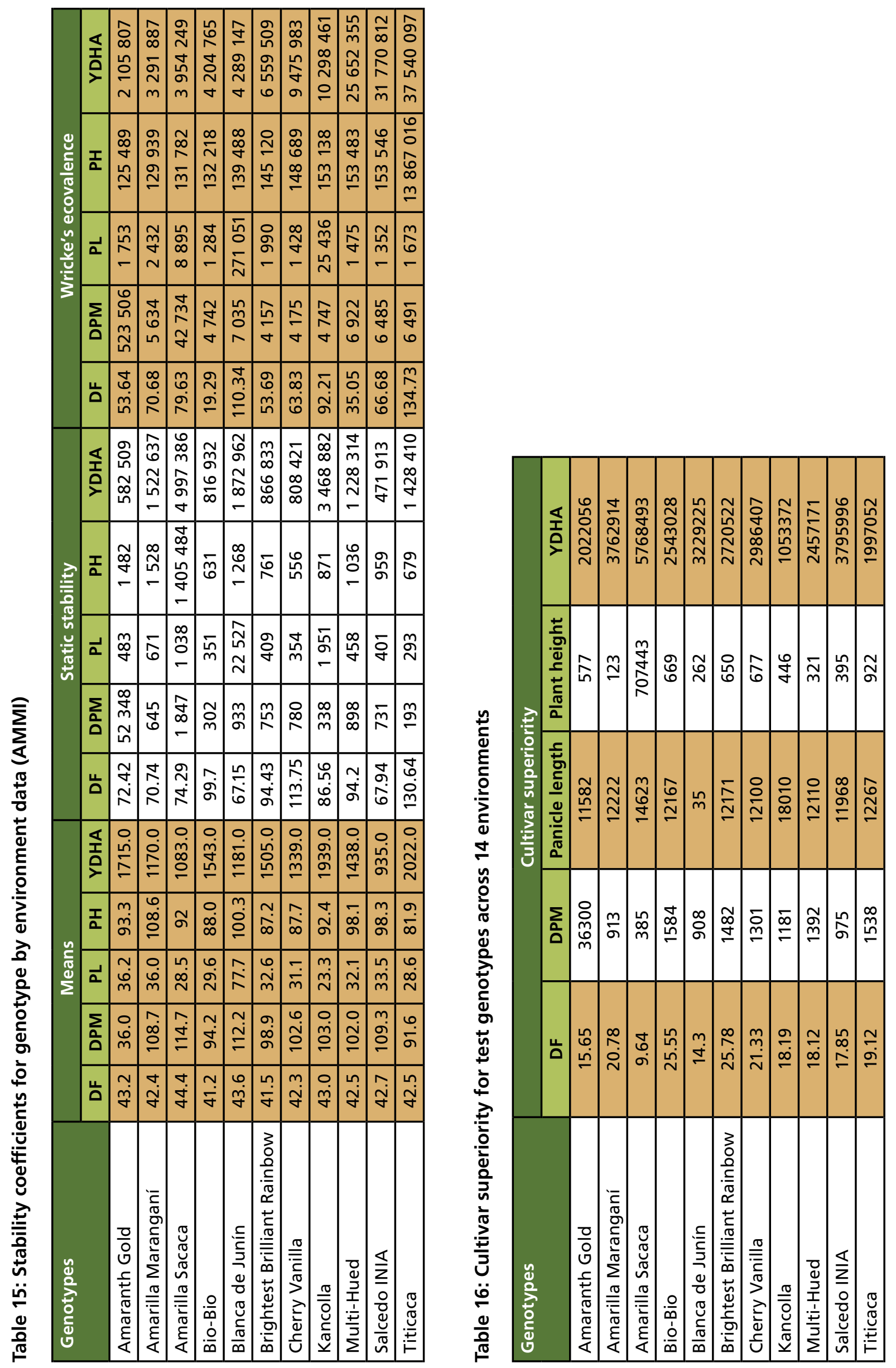
two as low-altitude (<1 000 m.a.s.l.), which included Nanga in Zambia and Tunyai in Kenya (Table 12). This could imply that quinoa is widely adapted to both low and high altitudes, a fact that has been well documented (Jacobsen et al., 2007; Geerts et al., 2008). Inclusion of more data sets from other countries could help to ascertain this fact for Africa. The data on temperature, rainfall and soil properties were incomplete and hence no relation could be made to tag a specific environmental factor as influencing the performance of the quinoa. Parameters that are usually modified by altitude and latitude, such as temperature, rainfall and season, need to be collected. In addition, some ecological zones receive winter rains while other sites receive summer rains. The current trials were conducted under irrigated conditions in some countries (Table 6) during different stages of plant growth, while in other countries the trials were conducted under rainfed conditions, all of which accounted for the variation in performance of the genotypes across the environments.

\subsubsection{Pests and diseases that affected quinoa in the trials}

Observations were made of incidences of pests and diseases, but no scoring was done on incidence or severity due to lack of training in conducting such assessments. Aphids were the single commonly observed pest that affected quinoa in the Kenya, Uganda and Zambia sites. In Uganda, the aphids were linked to plant stunting and leaf curling. Another pest observed was caterpillars that affected the leaves (forming webs, perforations and crinkling), panicles and stem bases (leading to plants breaking from the soil surface).

A few disease symptoms were observed on the quinoa genotypes. Leaf spots were observed on Amaranth at Buginyanya in Uganda, as well as virus-like symptoms (leaf mottling and shrinking) and infected plants were observed to have flowered earlier than uninfected plants. Damping-off symptoms were also observed and were attributed to soil organisms that needed to be ascertained. Insects similar to pod suckers, pod beetles that affect legumes and ladybird beetles were also reported from some of the trials. There is a need to include entomologists, plant pathologists, nematologists and soil scientists for their expertise in the identification of pests and diseases observed in the trials. Training of field staff engaged in similar trials on common pests and diseases that occur in quinoa will help in the documentation of this crucial data.

\subsection{Nutrient content in quinoa grown in different environments}

As African countries introduce and promote quinoa into their food systems, variation in nutritional composition of the crop's grain need to be known if it can significantly vary from one environment to another, especially with variation in soil fertility. The potential of quinoa to improve African diets would be realized if the nutritional profile of the grain grown in different African environments were similar or higher than grain grown in the Andean environments (Lughano et al., 2017 (in review)). Earlier studies indicated that the nutritional profile may vary with location and environmental factors. For example, variations in seed yield, total protein content and amino acid composition among cultivars grown in Andean highlands and the Argentinean Northwest were due to environmental and climatic factors (Gonzalez et al., 2012). The current FAO-supported project also supported a study on the effect of genotype and environment on protein content and amino acid in selected tested genotypes, conducted by CIAT (Nairobi) (Table 17). Quinoa grain samples of Titicaca, Brightest Brilliant Rainbow and Kancolla genotypes were drawn from quinoa harvest grown in Uganda (Mbarara and Namulonge trial sites) and Zambia (Mount Makulu trial site). Protein content in the three genotypes was least in grain from Mount Makulu trial site in Zambia $(\mathrm{P}<0.05)$. For the Titicaca and Brightest Brilliant Rainbow genotypes, the non-essential and essential amino acids were highest in genotypes grown at Namulonge $(\mathrm{P}<0.05)$ (Table 16$)$, attributed to variation in soil status. 
Table 17. The protein content $(\%)$ and amino acid profile $(\mu \mathrm{g} / \mathrm{g})$ of quinoa seeds grown in different research sites in Uganda (Mbarara and Namulonge) and Zambia (Mount Makulu) (Lughano et al., 2017 (in review))

\begin{tabular}{|l|c|c|c|c|c|c|c|c|}
\hline \multirow{2}{*}{} & \multicolumn{7}{|c|}{ Titicaca } & \multicolumn{3}{c|}{ BBR } & Kancolla \\
\cline { 2 - 7 } & Mbarara & Namulonge & $\begin{array}{c}\text { Mount } \\
\text { Makulu }\end{array}$ & Namulonge & $\begin{array}{c}\text { Mount } \\
\text { Makulu }\end{array}$ & $\begin{array}{c}\text { Mount } \\
\text { Makulu }\end{array}$ \\
\hline Protein & $17.22 \pm 0.32 \mathrm{c}$ & $16.17 \pm 0.23 \mathrm{~b}$ & $14.23 \pm 0.25 \mathrm{a}$ & $16.93 \pm 0.15 \mathrm{~A}$ & $14.33 \pm 0.21 \mathrm{~B}$ & $13.13 \pm 0.25$ \\
\hline Non-essential amino acids \\
\hline Aspartic acid & $1.49 \pm 0.19 \mathrm{a}$ & $1.57 \pm 0.13 \mathrm{a}$ & $1.60 \pm 0.14 \mathrm{a}$ & $1.69 \pm 0.10 \mathrm{~A}$ & $1.64 \pm 0.11 \mathrm{~A}$ & $1.51 \pm 0.05$ \\
\hline Serine & $0.86 \pm 0.17 \mathrm{a}$ & $1.29 \pm 0.29 \mathrm{~b}$ & $1.06 \pm 0.10 \mathrm{a}, \mathrm{b}$ & $1.03 \pm 0.15 \mathrm{~A}$ & $1.17 \pm 0.14 \mathrm{~A}$ & $1.03 \pm 0.10$ \\
\hline Glutamic acid & $2.70 \pm 0.18 \mathrm{a}$ & $2.600 .08 \mathrm{a}$ & $2.48 \pm 0.04 \mathrm{a}$ & $2.59 \pm 0.08 \mathrm{~B}$ & $2.21 \pm 0.17 \mathrm{~A}$ & $2.22 \pm 0.15$ \\
\hline Proline & $0.95 \pm 0.17 \mathrm{~b}$ & $1.14 \pm 0.03 \mathrm{~b}$ & $0.70 \pm 0.03 \mathrm{a}$ & $0.76 \pm 0.02 \mathrm{~B}$ & $0.70 \pm 0.06 \mathrm{~A}$ & $0.65 \pm 0.03$ \\
\hline Glycine & $1.25 \pm 0.15 \mathrm{a}$ & $1.24 \pm 0.14 \mathrm{a}$ & $1.22 \pm 0.28 \mathrm{a}$ & $1.28 \pm 0.23 \mathrm{~A}$ & $1.30 \pm 0.23 \mathrm{~A}$ & $1.20 \pm 0.24$ \\
\hline Alanine & $0.74 \pm 0.02 \mathrm{a}$ & $0.92 \pm 0.09 \mathrm{~b}$ & $0.80 \pm 0.13 \mathrm{a}, \mathrm{b}$ & $0.95 \pm 0.09 \mathrm{~A}$ & $0.84 \pm 0.12 \mathrm{~A}$ & $0.83 \pm 0.11$ \\
\hline Tyrosine & $0.54 \pm 0.15 \mathrm{a}$ & $0.43 \pm 0.04 \mathrm{a}$ & $0.43 \pm 0.05 \mathrm{a}$ & $0.46 \pm 0.03 \mathrm{~B}$ & $0.44 \pm 0.04 \mathrm{~A}$ & $0.37 \pm 0.02$ \\
\hline Arginine & $1.73 \pm 0.15 \mathrm{~b}$ & $1.59 \pm 0.02 \mathrm{~b}$ & $1.27 \pm 0.01 \mathrm{a}$ & $1.22 \pm 0.05 \mathrm{~A}$ & $1.14 \pm 0.06 \mathrm{~A}$ & $1.14 \pm 0.03$ \\
\hline Essential amino $\mathrm{acids}$ & $0.95 \pm 0.23 \mathrm{a}$ & $0.77 \pm 0.10 \mathrm{a}$ & $0.78 \pm 0.09 \mathrm{a}$ & $0.85 \pm 0.09 \mathrm{~A}$ & $0.81 \pm 0.09 \mathrm{~A}$ & $0.77 \pm 0.09$ \\
\hline Threonine & $0.77 \pm 0.07 \mathrm{a}$ & $0.92 \pm 0.03 \mathrm{~b}$ & $0.80 \pm 0.06 \mathrm{a}$ & $0.92 \pm 0.11 \mathrm{~A}$ & $0.83 \pm 0.07 \mathrm{~A}$ & $0.76 \pm 0.10$ \\
\hline Valine & $0.20 \pm 0.03 \mathrm{~b}$ & $0.28 \pm 0.02 \mathrm{c}$ & $0.16 \pm 0.02 \mathrm{a}$ & $0.27 \pm 0.01 \mathrm{~B}$ & $0.13 \pm 0.01 \mathrm{~A}$ & $0.12 \pm 0.06$ \\
\hline Methionine & $0.70 \pm 0.04 \mathrm{a}$ & $0.73 \pm 0.01 \mathrm{a}, \mathrm{b}$ & $0.77 \pm 0.02 \mathrm{~b}$ & $0.83 \pm 0.01 \mathrm{~B}$ & $0.78 \pm 0.06 \mathrm{~A}$ & $0.72 \pm 0.06$ \\
\hline Isoleucine & $1.07 \pm 0.04 \mathrm{a}$ & $1.21 \pm 0.03 \mathrm{~b}$ & $1.18 \pm 0.02 \mathrm{~b}$ & $1.29 \pm 0.02 \mathrm{~B}$ & $1.18 \pm 0.08 \mathrm{~A}$ & $1.14 \pm 0.07$ \\
\hline Leucine & $0.58 \pm 0.04 \mathrm{~b}$ & $0.62 \pm 0.04 \mathrm{~b}$ & $0.44 \pm 0.02 \mathrm{a}$ & $0.51 \pm 0.03 \mathrm{~B}$ & $0.42 \pm 0.03 \mathrm{~A}$ & $0.37 \pm 0.08$ \\
\hline Phenylamine & $1.32 \pm 0.34 \mathrm{a}$ & $1.26 \pm 0.02 \mathrm{a}$ & $1.01 \pm 0.10 \mathrm{a}$ & $1.02 \pm 0.17 \mathrm{~A}$ & $0.86 \pm 0.12 \mathrm{~A}$ & $0.98 \pm 0.13$ \\
\hline Lysine & $1 . \pm 10 \pm 0.50 \mathrm{a}$ & $0.84 \pm 0.08 \mathrm{a}$ & $0.56 \pm 0.05 \mathrm{a}$ & $0.56 \pm 0.06 \mathrm{~A}$ & $0.58 \pm 0.11 \mathrm{~A}$ & $0.54 \pm 0.03$ \\
\hline Histidine & & & & & \\
\hline
\end{tabular}

Values with different superscript letters within a row were statistically different $(\mathrm{P}<0.05)$ according to the Duncan test. BBR: Brightest Brilliant Rainbow

The results further established that the environments in Uganda resulted in a better nutritional profile of the three quinoa genotypes. Soil $\mathrm{pH}$ was found to have influenced protein content of the seeds whereby high $\mathrm{pH}$ corresponded with low protein content, which was the case for Mount Makulu in Zambia. The study results also showed correlations of high soil nitrogen status with high protein content in the grain and likewise high-altitude sites had high protein content in the grains. The implication of these results is that where soils are low in nitrogen status, application of nitrogen fertilizers will be a requirement. Where soil $\mathrm{pH}$ is high, soil amendments to lower the $\mathrm{pH}$ may be required that significantly increase protein content in the grain (Table 17). The levels of different types of amino acids were found to vary among the genotypes and sites. Selection of quinoa genotypes for specific environments therefore needs to consider the nutritional content of the genotypes.

\subsection{Quinoa awareness and promotion}

Activities to promote quinoa were conducted in Kenya and Uganda. In Kenya, three workshops were held at KALRO in Embu, with participants from six counties. A sensitization event was also conducted at a farmers' agricultural show, where 46 subjects (17 male and 29 female) assessed the suitability of quinoa incorporation into five common dishes - quinoa porridge, composite products of wheat and quinoa pastries (chapati and mandazi), maize and quinoa flour to make stiff porridge (ugali) and boiled quinoa grains. After assessing the recipes using a nine-point hedonic scale, over 80 percent of the subjects ranked four recipes (porridge, chapati, mandazi and ugali) as acceptable, while 50 percent slightly liked or disliked boiled quinoa grains. In Uganda, the quinoa trials were used as demonstration and training plots for Bachelor of Science in Agriculture intern students from 
Makerere University who got acquainted with the crop through participating in thinning, weeding and mulching of the crop.

Activities to raise awareness about quinoa and promote its use in Malawi included presentations of research findings at various national conferences and meetings as well as special stakeholder workshops for the TLC and LUANAR quinoa projects. In 2015 and 2016, women groups in two districts of Dowa (in Nalunga EPA) and Nkhotakota (Nkhunga EPA) were organized into nutritional groups for training sessions in the preparation of quinoa grain for various products. In Nkhunga EPA, a group of more than 10 women participated in quinoa growing for nutritional purposes. The communities have reached an understanding that quinoa has the potential to provide nutritious supplement in diets of children and mothers who are more vulnerable to food and nutritional insecurity. Nutrient composition analyses of the grain and leaf conducted by LUANAR have shown nutrient values (i.e. protein and minerals) as high as those reported from traditional quinoa growing areas.

To facilitate dissemination of quinoa in the farming communities, seed of the two best-performing varieties in each of the six EPAs in Malawi was supplied to 10 or more farmers for household growing and consumption. This resulted in 220 more households participating in quinoa growing, thereby extending the awareness of this nutritious grain crop.

Farmers, especially the women, have discovered that the leaf provides a tasty cooked vegetable meal. Women groups participating in nutrition programmes of Nkhunga and Nalunga EPAs have embraced the quinoa leaf vegetable in their diets and prefer this to other local leafy vegetables such as Amaranthus. Quinoa leaves do not have a bitter taste when cooked, unlike some Amaranthus types. This has further piqued the interest in planting quinoa not only for grain but also as a vegetable. The leaf is a source of ash, protein, iron and zinc (Mwangwela, 2015, of LUANAR, unpublished).

The International Year of Quinoa (IYQ) in 2013 highlighted quinoa's potential to change its status from a minor to a major crop in world agriculture based on the role that its biodiversity and high nutritional value can play in providing global food security. Faced with the challenge of increasing the production of quality food to feed the world's population within the context of climate change, quinoa offers an alternative for many countries suffering from food insecurity. The drive to expand the culture of quinoa did not end after 2013, and more than 26 new countries were looking forward to experimenting with it in 2014/15. The multiplication and spread of experimental stations are directly linked to major international research initiatives. The number of quinoa research centres is increasing worldwide. In parallel, the number of researchers working on quinoa is expanding, even in regions such as Eastern Europe or Central America which are not yet producing quinoa. However, the traditional producers of quinoa are still the main countries to conduct research.

It is evident that there are still big knowledge gaps in Africa, for example. These need to be addressed to increase the chances of its introduction and development in Africa. There is an imbalance in technology access between North and South Africa. For the IYQ2013, the coordination of a book called 'State of the art report on quinoa around the world in 2013' assisted in reviewing all the available knowledge on quinoa compiled by more than 160 co-authors in 43 book chapters (Bazile et al., 2015). But this was not enough, and the Global Collaborative Network on Quinoa (GCN-Quinoa.org) was developed to serve as a tool for fostering the development of inclusive, respectful, responsible and ethical quinoa programmes and projects across the world. The global dimension of this initiative is of high importance to connect Andean countries to new country producers in order to avoid conflicts by generating greater mutual understanding and partnerships. The network's four main objectives are:

- To create a global collaborative network on quinoa to support the co-development and exchange of technologies to multiple stakeholders responding to specific needs in developing countries, especially for food security;

- To promote access to a wide range of technologies considering not only information sharing but also capacity building for conservation, characterization, evaluation and sustainable use of quinoa's GR;

- To support South-South Cooperation as a tool for technical assistance between countries through partnership mechanisms for collaboration and mutual support; and 
- To facilitate the emergence of the Andean Quinoa Farmers Network (Argentina, Bolivia, Chile, Ecuador and Peru) for establishing strategic linkages between farmers' and researchers' networks (RAPQUINUA and GCN-QUINOA) in order to develop a common participatory research agenda.

The network initiated by Dr Didier Bazile of the French Agricultural Research Centre for International Development (CIRAD) has connected all the participants of the FAO-TCP programmes. A consultant was contracted for contributing to the design of the participatory website and the web domain was registered (http://gcn-quinoa.org/). Now, the GCN-Quinoa links 279 members from all around the world (more than 70 countries).

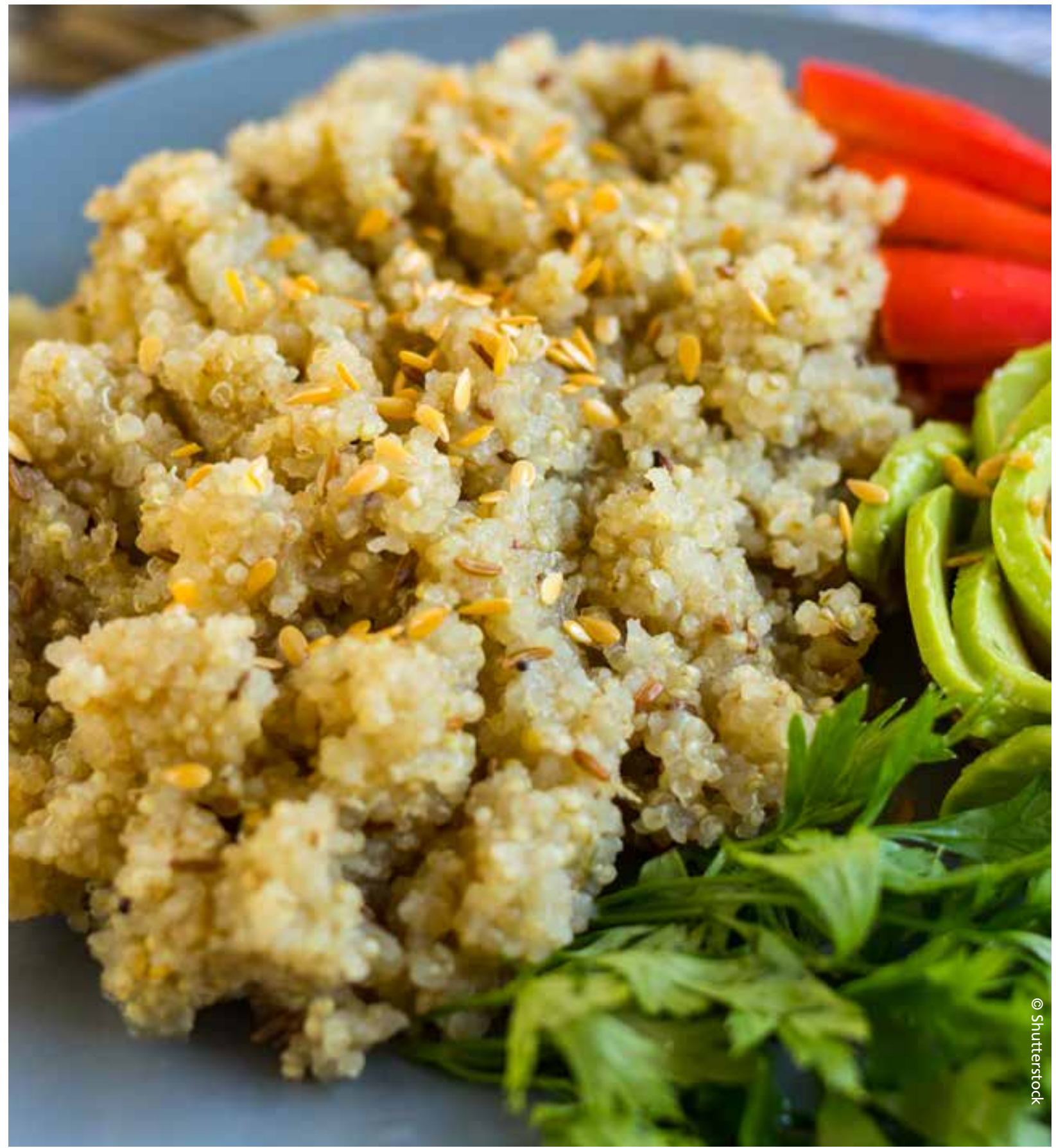




\section{Institutional considerations}

The various projects that have been conducted to introduce and promote quinoa in Africa show the need for several institutional considerations to be made for the initiative to be successful at local, national and regional level. These considerations include and pertain to:

\subsection{Acquisition of quinoa germplasm}

Engagement of international organizations like FAO and CIAT proved to be an effective way of acquiring quinoa germplasm for introduction to African regions. The Andean countries were more willing to share their germplasm with other countries with a trusted organization like FAO coordinating the acquisition of the germplasm. If African countries are to acquire more germplasm from the Andean countries for further introductions and adaptation studies, it may be easier to do it as a group through the negotiating power of the FAO. However, time was lost in the process of shipment and the time it took to distribute the seed to the respective country institutions, which led to loss of seed viability by the time countries received the seed. Requesting the donor of the germplasm to ship the seed directly to specific countries would minimize such seed viability problems. This was evidenced by the experience of countries that acquired the germplasm through other research collaborators as was the case with Malawi or with earlier studies in Ethiopia and Kenya. These countries did not experience the poor seed germination reported in the recent trials.

\subsection{Institutional mandate and quinoa research}

The approach of engaging national public research institutions to introduce quinoa has the advantage of gaining public trust in the new technology. The national agricultural research institutions (NARIs) are all under ministries of agriculture and have a well-established network of research station infrastructure and personnel across the ecological zones of these countries. Multi-locational trials were therefore easily organized in Ethiopia, Kenya, Uganda and Zambia. The NARIs' strengths also include availability of multidisciplinary expertise in agricultural research such as plant breeders, agronomists, plant pathologists, as well as experts in food processing and human nutrition that facilitates the coordination of quinoa introduction and promotion. The engagement of CIAT in this regional quinoa project brought CGIAR research expertise and experience into quinoa research in breeding and human nutrition that have played a critical role in the formulation of the strategy that needs to be embraced as the region adopts quinoa. CIAT efficiently coordinated the technical processes including germplasm distribution, soil sample and seed nutrient composition analyses, data analyses and regional report writing.

The spectrum of institutions involved in quinoa research, production and utilization at national levels needs to include public sector development agencies and agricultural research institutes, nongovernmental organizations, public and private universities and corporations, with each contributing different perspectives, strengths and resources to help meet the challenge. NARIs provide advice to local farmers, diffusing the new knowledge into the country's agriculture system. In the current case of countries (Ethiopia, Kenya and Zambia) where quinoa was evaluated, the national agricultural research institutions of ministries of agriculture were the leading institutions, with the exception of Malawi where an agricultural university (i.e. LUANAR) took the lead. It is expected that the involvement of NARIs in introducing quinoa in most developing countries will be more effective in accelerating adoption of the new crop by farming communities. Where possible, the research institutions should engage partner institutions or organizations for the full duration of projects so as to share the full extent of the expertise and knowledge involved, rather than engagement in one-way or one-time transfer of the technology. 


\subsection{Institutional capacity building to conduct quinoa research}

Quinoa being a new crop on the continent, there is limited human capacity with knowledge and expertise to conduct quinoa research without prior training to acquaint researchers with the crop. Although quinoa is similar to Amaranthus, which is a familiar crop in Africa, it has phenological and physiological differences and pests and diseases that would affect its successful introduction. Training of researchers to be engaged in quinoa experiments is required so that agronomic practices can be applied at the appropriate stage of the crop and so that the crop can be harvested at the right stage to minimize shatter loss and soil contaminants. There is also a need to build capacity in threshing and postharvest handling of the seed.

While most of the participating countries had human resource capacity to conduct the quinoa research, some of them did not have the technical capacity, or had limited capacity at the Ministry of Agriculture (MoA) level. In Somalia, there was a coordinated effort between FAO and the MoA to set the trials in a conducive environment. FAO trained the MoA on how to implement the trials and to ensure that protocols were properly followed and trials implemented in the standardized conditions. An expert agronomist based in the area of implementation of the trials was recruited by FAO to ensure proper daily follow up on the process. However, staffing changes within the MoA of Somalia made it difficult for the expert to coordinate the quinoa trials in the country, and hence no data were generated on these quinoa trials.

\subsection{Universities - academic research}

Engagement of agricultural universities in quinoa research provided judicious use of trained human resources, infrastructure and other resources emanating from the universities' role of teaching, research and outreach. In the short term, short training courses can be organized for the researchers while in case of long-term capacity building, universities (LUANAR and Jomo Kenyatta) are engaging undergraduate and postgraduate research projects. The universities are assisting in developing both new emerging crops and orphan crops, promoting successful agriculture for marginal ecological conditions and tackling small-scale technological problems. Such work accounts for much of the research conducted by local institutions and needs to be strengthened. The collaboration demonstrated in this research work suggests the need for local institutions to provide incentives for their staff to collaborate with international researchers and seek synergies with research done elsewhere. The CGIAR centres such as CIAT played an important role in helping to integrate local efforts with the knowledge available worldwide.

\subsection{Non-governmental organizations}

Partnerships with non-governmental organizations that are engaged in development projects with farming communities appear to accelerate adoption of quinoa by the farmers, as in the case of Total Land Care (TLC) in Malawi which partnered with LUANAR to conduct on-farm studies of quinoa with the farming communities in its impact area. As the farming communities had already established trust in TLC they readily agreed to host the trials. 


\section{Policy considerations}

Quinoa is alien to Africa and its introduction requires supporting policies by governments to integrate new crops into their agriculture and food systems. Many rural populations in Eastern and Southern Africa are heavily dependent on a few crops such as maize (Zea mays L.), rice (Oryza sativa L.) and wheat (Triticum aestivum L. em. Thell.). Limited to specific cultural groups are many 'orphan' or underutilized crops of regional or local importance for nutrition and income. Many agricultural policies in these countries are encouraging research and promotion of indigenous and locally adapted crops for food security. Encouraging research by scientists, accessing funding for quinoa studies and utilizating quinoa as a global emerging crop need to be integrated in the crop production policies.

Seed multiplication for released varieties of quinoa will require proper regulation just like the traditional major food crops to ensure maintenance of high seed quality. Quinoa is a self-pollinated crop with about 10 to 15 percent (and sometimes up to 30 percent) cross-pollination, which could be responsible for the off-types observed in some of the varieties tested in the seven Eastern African countries and in Malawi. Countries need to review or check if their current policies and regulations that cover the other traditional self-pollinated crops can adequately regulate seed multiplication and maintenance of commercialized varieties of quinoa. African countries may have to learn from the countries where quinoa has been commercialized for a long time such as the Andean region. Success in the promotion of quinoa will depend on the effective regulation of the seed system in order to ensure farmers' access to quality seeds of varieties that meet their production, consumption and marketing conditions. Access implies affordability, availability of a range of appropriate varietal seed and possessing information about the adaptation of the variety. It is important to recognize that most small-scale farmers in developing countries obtain seed from the informal seed sector, which provides traditional farmer-bred varieties and saved seeds of improved varieties. The majority of small-scale farmers are likely to save and recycle their own seed unless they appreciate the benefits of using certified seed of quinoa. Such benefits need to be included in the awareness programme at the early stages of quinoa promotion.

Quinoa was primarily introduced into Africa to benefit the diets of the rural African population. However, the growing demand for quinoa in developed countries may turn quinoa into another purely commercial crop like tobacco if its production and export to international markets are not regulated. The African farmers may end up being producers of the grain to supply developed countries while the local farming communities continue to depend solely on their indigenous crops for their diets, even though the quinoa crop has a high nutritional value for the local population. This was clearly observed to be an important issue during the closing workshop (January 2016) of the FAO-supported quinoa pilot trials in Addis Ababa. Policies or regulations that can promote domestic utilization of quinoa may be required to guide the agro-processors. Others argue that if small-scale farmers can realize improved economic status out of exporting quinoa, then this will be translated into improved diets. A challenge in past experiences has been that the benefits of an export crop do not proportionally trickle down to the farmers.

Quinoa has been reputed to perform well even in marginal environments, an advantage governments can use to promote its production in ecological zones where the traditional staple food crops do not perform well. Quinoa needs to be included among the food crops being promoted for marginal environments and climate change adaptation.

Increased funding will be required for research and promotion of crops like quinoa that are candidates in adapting to climate change. The potential of the quinoa crop to help farmers adapt to climate change impacts may not be realized unless governments allocate more funds to research and development of the crop for sustainable funding rather than depend solely on donor grants for research. 


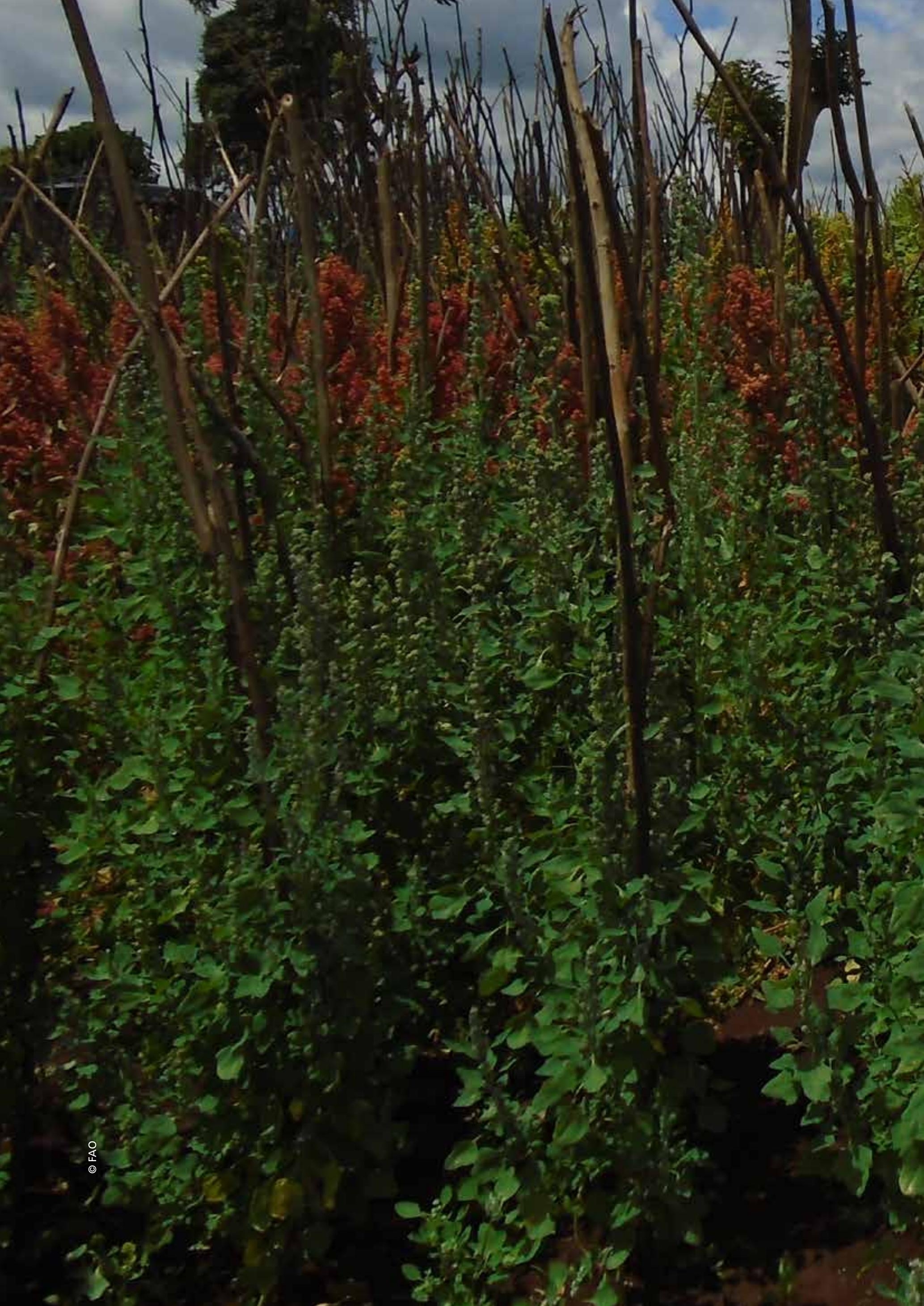




\section{Lessons from the successes and challenges}

Several lessons that include both successes and challenges can be drawn from the quinoa trials conducted so far (particularly from the Eastern and Southern African countries).

\subsection{Successes}

\subsubsection{Awareness among public and non-governmental institutions}

The quinoa introductions and pilot evaluation trials generated awareness among both the public research institutions and universities and the non-governmental organizations working with farming communities and those promoting improvement of diets. Researchers in NARIs and universities that conducted the trials engaged stakeholders from government, non-governmental institutions, farming communities and the media in planning meetings, workshops and field days. Interest in quinoa has grown significantly because of its nutritional superiority and wide environmental adaptation. It shows excellent adaptability, is able to produce in unfavourable soil and climatic conditions and has high nutritional value - it contains high levels of protein, is rich in vitamins and minerals, and is gluten-free.

Many people and organizations feel that with the increasing world population, more attention should be paid to major world cereals in order to feed people. This may be the case for productive areas, but not for marginal and degraded ones where minor cereals and pseudocereals are more adaptive and higher yielding (Williams, 1995). Quinoa is suited to such areas, especially in view of climate change. The effects of climate change are well-known and include increased temperatures, high-altitude and high-latitude areas more prone to warming, prolonged drought in arid and semi-arid regions, increased flooding, extreme weather events and rising sea level. Overall, the climate is changing faster than species are able to adapt, making quinoa one of the best options.

\subsubsection{Plant growth and yield}

Results from the evaluation trials conducted so far in Ethiopia, Kenya, Malawi, Zambia and Uganda have demonstrated that quinoa can be grown successfully in the various ecological environments of the region (Mukankusi et al., 2016). The nutritional composition of the seed was shown to vary with the environment (particularly soil fertility) (Lung'aho et al., 2020 (in review)), but remained within the range of nutritional composition of quinoa grown elsewhere. Some of the 16 introduced genotypes such as Amarilla Maranganí, Brightest Brilliant Rainbow, Cherry Vanilla, Titicaca and Multi-Hued can be selected for specific environments for production and utilization. What is further required is to evaluate these genotypes over different seasons and in additional sites to validate their performance.

\subsubsection{National quinoa research capacity}

The FAO-TCP-funded quinoa project succeeded in bringing germplasm of six genotypes (Table 6) from Bolivia. It also succeeded in building the capacity of the seven countries participating in the project through training workshops and financial resources that enabled the national research teams to implement the trials. The trials also served as nurseries for seed multiplication of the introduced varieties that can be used for further trials. The scientists involved gained experience in quinoa crop production from the pilot evaluation trials under their local conditions.

\subsubsection{Quinoa research network}

A network of researchers on quinoa was established among the NARIs' research teams, providing a platform for sharing of information on quinoa research in the region and with other international 
scientists. The network served as a formal collaboration mechanism for quinoa development in the region, with membership comprising the seven countries participating in the FAO-TCP project as well as FAO and CIAT. The network encouraged sharing of germplasm for the mutual benefit of member countries and served as a platform for knowledge and information exchange. An extension of this project is expected to seek development and promotion of a regional programme on quinoa that addresses both nutrition and gender equity; sharing of responsibility for the development of quinoa in the region by providing a pool of institutional, human and technological capacity for quinoa research for development (R4D); use of advocacy, policy dialogue and communication approaches to convey evidence-based information on quinoa and, where possible, to support and promote collaboration and coordination of quinoa R4D activities.

\subsection{Challenges}

Several challenges were encountered during the early stages of quinoa introduction in Africa. Abiotic and logistical challenges, institutional and policy issues that affected implementation of the trials are discussed and refer to all seven countries (thus adding Djibouti, Somalia and South Sudan where introduction was attempted) in several respects.

\subsubsection{Acquisition of quinoa germplasm from the Andean countries}

Acquisition of germplasm from the Andean countries was challenged by delays attributed to logistics in the delivery of seed, more specifically from Peru, which took a long time to reach the participating countries and the experimental sites. For instance, in some cases it took up to eight months for seed from Peru to reach participating countries. Monitoring of seed quality and storage conditions within transit was not assured and consequently the seed lost viability while in transit. Future acquisition of more varieties may work better if the seed is first multiplied in each country and fresh seed is used for further experimentation. The planting of the seed whose viability was questionable resulted in variable plant populations in experimental plots.

\subsubsection{Poor seed quality}

Germination and establishment were major problems faced in all the experimental sites. Poor seed germination or complete germination failure was reported, particularly among the seeds from Peru. This was attributed to the long transit period during which proper seed handling was not assured. In contrast, seed from Malawi showed a better germination percentage. Seed testing for viability needs to be conducted for germplasm acquired from elsewhere before sowing is done for an experimental trial. In most circumstances only small quantities of germplasm seed are shared and seed multiplication prior to setting up trials would ensure that rejuvenated seed with high quality is used for trial sowings and minimized variation in plant densities.

\subsubsection{Lack of experience in quinoa crop management}

Challenges associated with crop management that were reported from almost all sites included plant lodging, sprouting of seed at physiological maturity and incidences of pests and diseases. Incidences of plant lodging were experienced from flowering to maturity stage, which was worse when the plants grew very tall and under rainfed conditions attributed to accumulation of water in the inflorescence. In the case of pre-harvest sprouting of seed, it occurs when physiologically mature plants are exposed to prolonged wet conditions. This is common when the maturity period coincides with periods of rain. Water accumulates within the inflorescence, providing a favourable environment for sprouting. Large, open inflorescences dry more quickly after the rains or dew than small compact ones (Jacobsen, 1997). Lodging incidence exacerbates sprouting as plant panicles tend to fall to the ground where soil moisture is usually high. Lodging also increases the presence of soil particles in the seed or grain after threshing. Lodging could be managed by staking the plants, but this may not be feasible when dealing with large fields. Use of relatively short-statured plant varieties would be easier to manage. Close plant spacing could also be experimented with to check if it can be applied to reduce plant lodging. Sprouting is easily controlled when the crop is grown under irrigated conditions by withdrawing watering as 
soon as the crop matures, but during a long rainy season it is difficult to minimize sprouting. Longduration varieties would have to be planted during long rainy seasons. Selection for sprout-resistant genotypes has been reported and this may be a preferable option for farmers.

Common pests observed were aphids and caterpillars, which are common in most horticultural crops. Diseases observed had symptoms of virus-like mottling and crinkling which could not be identified due to limited expertise of the research teams. There is a need to include plant protection expertise (entomologists and plant pathologists engaged or closely consulted) in quinoa trials.

\subsubsection{Unfavourable climatic conditions}

Erratic weather challenged the performance of the quinoa trials. In some sites the crop's sensitive growth stages, like emergence, coincided with hot dry weather and good plant establishment became difficult. Despite its wide adaptation from sea level to over 4000 m.a.s.l. and in drought-prone regions, quinoa's drought tolerance is not completely elastic. The crop needs some water applications during water-sensitive stages of growth and irrigation can significantly increase yields (Bosque Sanchez et al., 2003; Garcia et al., 2003). In some cases, there was too much rain battering the plantlets, which also resulted in poor establishment or sprouting. Mulching of the beds sown to quinoa up to two weeks after emergence has been tried in Malawi and found to reduce the impact of too much rain until plants are established, while it also helps to conserve moisture in the case of dry spells. Nevertheless, irrigated quinoa grain yields have been higher than under rainfed conditions (Maliro et al., 2017).

\subsubsection{Postharvest processing and handling}

Challenges also emerged during harvesting and processing in the absence of mechanization. Varieties that experienced lodging problems had panicles carrying soil particles from the ground. There were problems separating the seed from debris-like soil particles due to small seed size, which is especially problematic in grain meant for consumption. Quinoa introduction studies and promotion efforts need to develop technologies that will improve the threshing methods and keep the seed/grain free of contaminants in both seed and grain for consumption. In Malawi a significant decline in viability of the quinoa seed was observed after six months of harvest (Nachipo, 2017) and therefore seed-drying and storage methods need to be studied as well as the shelf life of the seed before it loses viability.

\subsubsection{Limited human and laboratory capacity}

Capacity to conduct quinoa trials varies among the participating countries and technical assistance to be provided to these countries should consider their unique challenges. While many countries had limited capacity to implement the trials, Somalia had limited technical research capacity at the Ministry of Agriculture level due to the absence of NARIs, or research facilities with limited technical personnel to implement the trials. This was attributed to Somalia's long history of political instability and insecurity that impacted on the existence of its government structures. Consequently, there were efforts to change the focal point for the quinoa project, but this came too late for the trials to be conducted within the project period. At the time the project ended, Somalia still had to conduct the trials. In South Sudan there was insecurity in some sites which made it difficult to reach the sites in time for soil sampling and trial implementation. In Zambia the trials were conducted under irrigated conditions during the dry season and during the plant growth period the sites encountered irrigation difficulties due to power outages which affected regular irrigation schedules.

Some of the countries like Djibouti did not provide soil analysis data, thereby limiting the comparison of results from sites of different countries to soil characteristics. Djibouti was also uniquely positioned in that it does not have enough land space for agricultural production of the traditional field crops and it was anticipated that if quinoa gave promising results, it would provide an opportunity for domestic food crop production. 


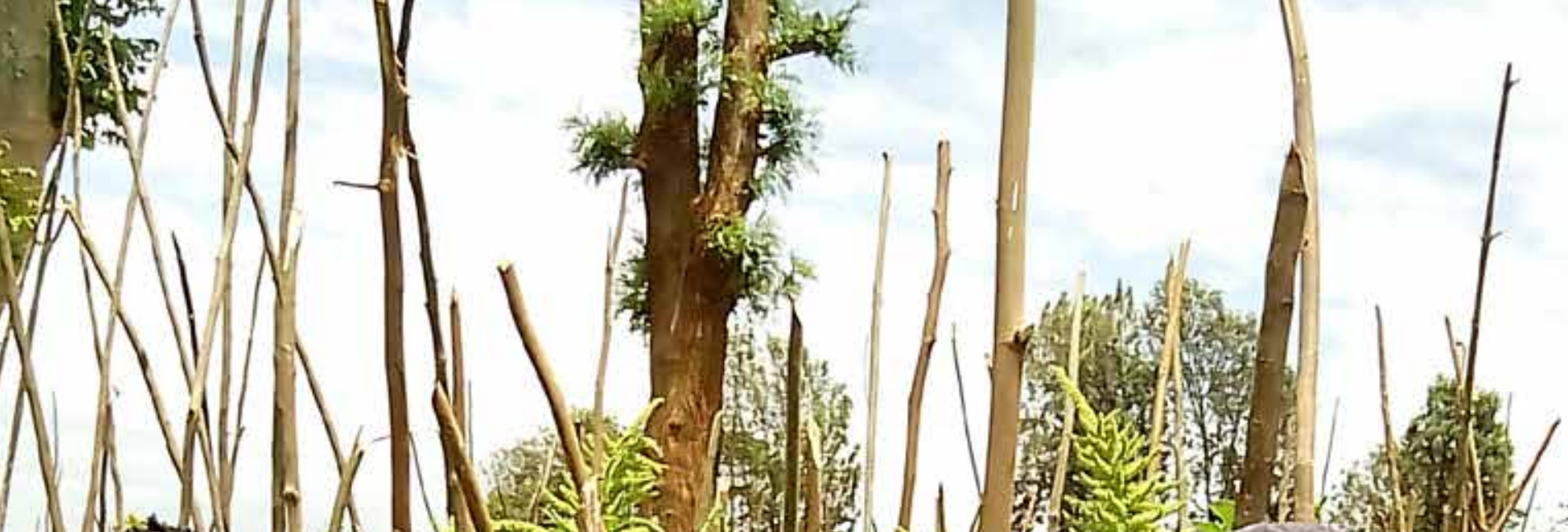

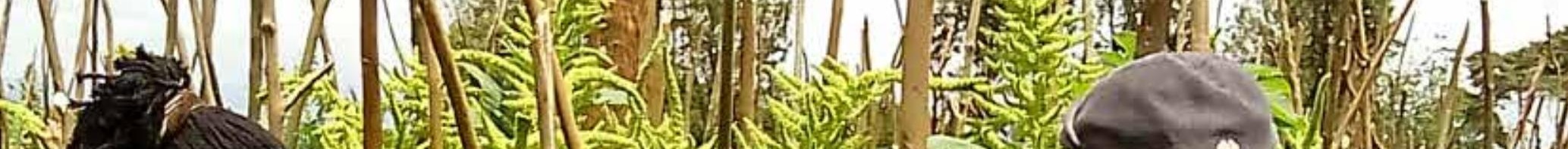

(i) 20

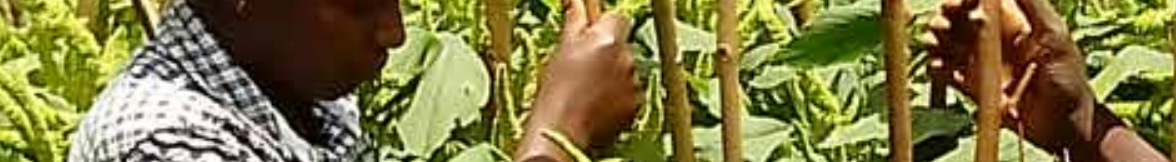

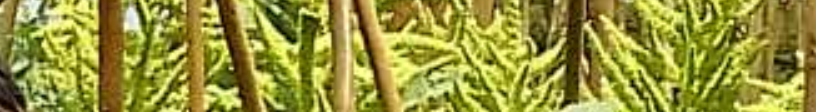

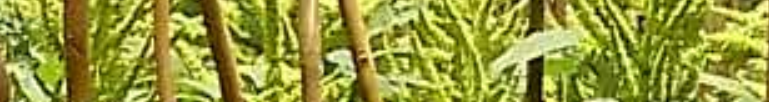

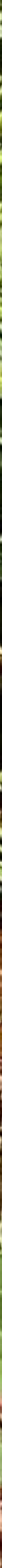

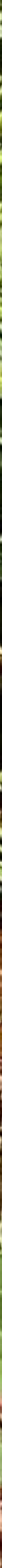

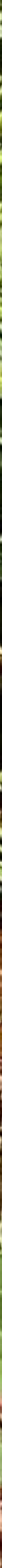

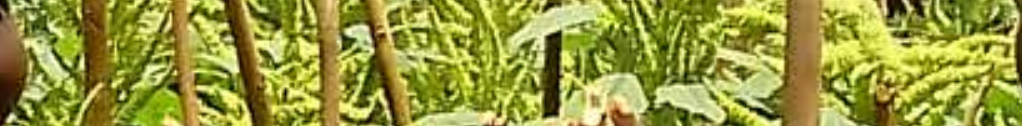
rif (i) (5)

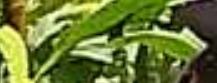
F)

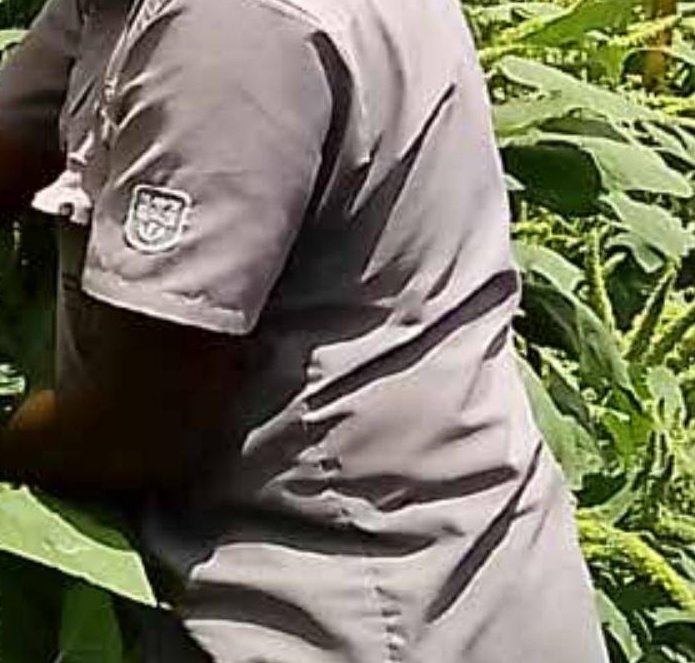




\section{Conclusions}

The data generated by the trials in the African countries have demonstrated that quinoa production is possible. It is no longer a question of whether quinoa can grow and yield enough seed/grain to warrant its production, but how quinoa can be introduced and integrated into the African food systems. Several technological, institutional and policy considerations need to be made to facilitate introduction and adoption of quinoa in farming communities of different agro-ecological areas of Africa and promote its utilization.

8.1 The exploratory trials showed that genotypes evaluated vary in their plant-growth and grainyield performance across different environments. For quinoa production to be possible across different ecological zones, local varieties adapted to specific ecological regions or zones need to be selected under these environmental constraints. Quinoa yields as high as those realized in traditional production areas of quinoa are possible. There are also some genotypes whose protein content and quality (amino acids) vary with soil nutrient status across environments.

8.2 Low seed viability constrained plant establishment in all sites of the evaluation trials under the FAO-TCP project. Quality of seed will therefore be a key factor for successful adaptation trials of quinoa as well as for promotion of the crop.

8.3 Variation in soil nutrient status was one of the factors that affected variation in quinoa performance across environments. Fertilizer requirements need to take soil nutrient status in each environment into consideration.

8.4 There are biotic stresses that include insect pests (particularly aphids and caterpillars), diseases (affecting the leaves) and moulds. However, diseases appear not to be a major constraint to quinoa production. While quinoa displays wide environmental adaptation, abiotic stresses such as droughts and soil factors like $\mathrm{pH}$ have an impact on its production.

8.5 Due to the physiological nature of quinoa seed, i.e. size and lack of dormancy, it needs proper processing to minimize contaminants and manage storage conditions after harvest.

8.6 The adaptation trials that have been conducted in the past in Ethiopia, Kenya and Malawi and the recent FAO-TCP project have created capacity for the African region to drive quinoa introduction and promotion on the continent. The researchers who were engaged in the trials represent the human capacity that is now knowledgeable and experienced in quinoa growing to some degree.

8.7 National agricultural research institutes (NARIs) already have a network of research infrastructure in place across agro-ecological zones in most of the countries, making them well-positioned institutions for quinoa introduction and promotion. Agricultural universities such as LUANAR in Malawi played an equally important role to introduce quinoa and conduct adaptability and on-farm studies. Non-governmental organizations that are working with farming communities as well as women on nutrition programmes became effective partners in the promotion of quinoa production and utilization, as was the case with TLC and LUANAR in Malawi.

8.8 Awareness creation about quinoa as a food crop with high potential to contribute to national food and nutrition security has started and needs to continue among policy-makers and the public in countries that participated in the project.

8.9 A regional approach to introducing quinoa has been effective as it provided a platform for sharing information and experience that would not otherwise have been possible. This regional platform needs to link to international experiences for sharing results and lessons learned among all participants. The Global Collaborative Network on Quinoa (GCN-quinoa.org) is a good option for developing that kind of collaboration and for exchanging human resources among institutions at a global level. 
8.10 Engagement of stakeholder institutions at the early stages of quinoa introduction increased awareness in most of the participating countries in Eastern Africa and Malawi. Farmers in Malawi appreciated the importance of quinoa grain and explored the use of the leaves as a vegetable.

8.11 In most countries, especially developing countries, agricultural research and production policies emphasize a few major cereal and legume crops for food security, while many indigenous food crops that have played an important nutritional security role in the farming households over the past centuries have been neglected by research and extension. Policy-makers can easily view quinoa as one of such 'orphan' or neglected crops if proper awareness is not created. 


\section{Recommendations}

Many recommendations could be made based on the lessons learned during the early quinoa trials in Ethiopia, Kenya and Malawi and those championed by the FAO-TCP quinoa project in 2015. Broad and specific recommendations put forward include:

9.1 The need for further testing of the genotypes in the seven countries as data generated so far are from a single season with the exception of Ethiopia and Malawi. Several gaps (seed quality, pathology, physiology, agronomy and genetics) remain for the researchers to understand quinoa as a potential crop for introduction into the African food systems. Expertise needs to be engaged to address the research gaps as multilocational trials extend to other agro-ecological zones. Making conclusions on the agronomic performance of quinoa in the region based on one season's data is not adequate and ideally three seasons' data will be required to reach concrete conclusions. Due to their interest in quinoa crops, a number of countries have proceeded to establish trials in more sites in the second season to cover the major agro-ecological zones (i.e. Kenya and Uganda). This should be encouraged for all participating countries.

9.2 Seed multiplication of the varieties or genotypes for the trials needs to be maintained at national or regional level to reduce challenges of low viability and genetic purity. Studies on storage conditions for quinoa seed shelf life are needed to understand the challenges associated with viability and pre-harvest sprouting of quinoa.

9.3 Wide adaptation of quinoa is not absolute. Specific genotypes or varieties will have to be selected for specific marginal environments. i.e. genotypes well-adapted to arid, semi-arid and saline or acidic soil conditions.

9.4 Fertilizer requirements for quinoa production need to be based on soil nutrient status to achieve the potential grain yield levels and nutrients (protein, amino acids and minerals) in the grain.

9.5 There is a need for capacity building of both scientists and technicians in quinoa crop research, which can take the form of short training courses or visits to countries that have had more experience with quinoa research in the region or to the Andean countries. Training in the use of the quinoa descriptors is required as well as in the improvement of the existing descriptors to make them more user-friendly. Training in data collection, curation and analysis is required by some members of the quinoa consortium. Support for undergraduate and postgraduate research on quinoa crop (agronomic and utilization) needs to be included for sustainability of the quinoa 'revolution' in Africa. A specific curriculum could be developed (Bazile et al., 2015), using the contents of Bazile and Bertero's state-of-the-art report on quinoa and their experiences for adapting the curriculum to East African contexts.

9.6 NARIs and agricultural universities should continue to lead the quinoa research in close partnership with farmers' organizations and NGOs that are working with farming communities.

9.7 There is more to be done to create awareness of quinoa as a health food. Engagement with policy-makers as well as other technocrats and the public needs to be intensified to influence adoption and utilization of quinoa to improve food and nutritional security.

9.8 The regional quinoa research network that is championed by FAO should continue to be supported to serve as a platform for the exchange of information and discussion among various stakeholders in the region. This regional platform needs to be connected to international experiences to enable global stakeholders to share results and learn from each other. The Global Collaborative Network on Quinoa (GCN-quinoa.org) is a good option for developing that kind of collaboration and for exchanging human resources among institutions at a global level.

9.9 National agricultural research and production policies need to accommodate funding and promotion of global emerging crops like quinoa so that national research scientists can have funding opportunities to develop varieties that will meet specific domestic and export needs. 


\section{Acknowledgements}

This paper was written based on end-of-project technical reports and workshop outputs of the technical cooperation programme (TCP) project titled "Technical assistance for the strengthening of the food system of quinoa" (TCP/SFE/3406) initiated and funded by FAO. Technical reports of Malawi's LUANAR and TLC's quinoa projects and experiences and publications on early quinoa trials in Ethiopia and Kenya were also consulted for this paper. 



\section{References}

Abugoch James, L. E. 2009. Quinoa (Chenopodium quinoa Willd.): Composition, chemistry, nutritional, and functional properties. In S. Taylor, ed. Advances in food and nutrition research (Vol. 58, pp. 1-31). Academic Press.

Amsalu, B. 2014. Country agriculture status and Quinoa (Chenopodium quinoa Willd.) research experience of Ethiopia. A presentation made at the 1st Regional Training Workshop and Network Meeting on Quinoa in Addis Ababa, Ethiopia from 24-28 November 2014.

Bazile, D. 2015. Le quinoa, les enjeux d'une conquête. Versailles: Ed. Quae, 111 p. (Essais: Quae).

Bazile, D. \& Baudron F. 2015. The dynamics of the global expansion of quinoa growing in view of its high biodiversity. In B. Didier, B.H. Daniel \& N. Carlos, eds. State of the art report on quinoa around the world in 2013. Rome: FAO, pp. 42-55.

Bazile, D. (ed.), Bertero, H.D. (ed.) \& Nieto C. (ed.). 2015. State of the art report on quinoa around the world in 2013. Rome: FAO, CIRAD, 603 p. http://www.fao.org/3/a-i4042e.pdf

Bazile, D., Jacobsen, S.E. \& Verniau, A. 2016. The global expansion of quinoa: Trends and limits. Frontiers in Plant Science, 7 (622): 6 p. http://dx.doi.org/10.3389/fpls.2016.00622

Bazile, D., Pulvento, C., Verniau, A., Al-Nusairi, M., Ba, D., Breidy, J., Hassan, L., Maarouf, I.M., Mambetov, O., Otambekova, M., Sephavand, N.A., Shams, A., Souici, D., Miri, K. \& Padulosi, S. 2016. Worldwide evaluations of quinoa: Preliminary results from post international year of quinoa FAO projects in nine countries. Frontiers in Plant Science, 7 (850): 18 p. http://dx.doi.org/10.3389/ fpls.2016.00850

Bertero, H.D., de la Vega, A.J., Correa, G., Jacobsen, S.-E. \& Mujica, A. 2004. Genotype and genotype-by-environment interaction effects for grain yield and grain size of quinoa (Chenopodium quinoa Willd.) as revealed by pattern analysis of international multi-environment trials. Field Crops Research 89:299-318.

Bertero, H.D., King, R.W. \& Hall, A.J. 1999. Photoperiod-sensitive development phases in quinoa (Chenopodium quinoa Willd.). Field Crops Research 60: 231-243.

Bhargava, A. \& Ohri, D. 2015. Quinoa in the Indian Subcontinent. Chapter 6.2. In FAO \& CIRAD. State of the Art Report of Quinoa in the World in 2013, pp. 511- 523. Rome.

Bhargava, A. \& Srivastava, S. 2013. QUINOA: Botany, Production and Uses. CAB International. ISBN 978-1-78064-226-0. Wallingford, UK.

Biodiversity International, FAO, PROINPA, INIAF \& IFAD. 2013. Descriptors for quinoa (Chenopodium quinoa Willd.) and wild relatives. Biodiversity International, Rome, Italy; Fundación PROINPA, La Paz, Bolivia; Instituto Nacional de Innovación Agropecuaria Forestal, La Paz, Bolivia; International Fund for Agricultural Development; Food and Agriculture Organization of the United Nations, Rome, Italy. ISBN: 978-92-9043-948-6.

Bosque Sanchez, H., Lemeur, R., Van Damme P. \& Jacobsen, S.E. 2003. Ecophysiological analysis of drought and salinity stress of quinoa (Chenopodium quinoa Willd.). Food Reviews International, 19: 111-119. 
Caperuto, L.C., Amaya-Farfan, J. \& Camargo, C.R. 2001. Performance of quinoa (Chenopodium quinoa Willd) flour in the manufacture of gluten-free spaghetti. Journal of the Science of Food and Agriculture, 81 (1) (2001), pp. 95-101.

Chakholoma, M. 2016. Response of quinoa (Chenopodium quinoa Willd) in plant growth and yield to time of planting under rain-fed conditions. A research project report submitted in partial fulfilment of the requirements for Bachelor of Science Degree in Agronomy, Faculty of Agriculture, Lilongwe University of Agriculture and Natural Resources (LUANAR), Bunda Campus, Lilongwe.

Coulibaly, A., Sangaré, A., Konate, M., Traoré, S., Ruiz, K.B., Martinez, E.A., Zurita, A., Antognoni, F., Biondi, S., Maldonado, S., Léon, P. \& Bazile, D. 2015. Assessment and adaptation of quinoa (Chenopodium quinoa Willd) to the agroclimatic conditions in Mali, West Africa: An example of South-North-South cooperation. In B. Didier, B.H. Daniel \& N. Carlos, eds. State of the art report on quinoa around the world in 2013. Rome: FAO, pp. 524-533. http://www.fao.org/3/a-i4042e.pdf

De Jene, T. A. 2015. Quinoa performing well in Ethiopia. An article paper reported in the DanChurchAid Newsletter of 16.10.2015, accessed in April 2017 at https://www.danchurchaid.org/news/news/quinoaperforming-well-in-ethiopia

Delatorre-Herrera, J. \& Pinto, M. 2009. Importance of ionic and osmotic components of salt stress on the germination of four quinoa (Chenopodium quinoa Willd.) selections. Chilean J Agric Res 69(4): 477-485. doi:10.4067/S0718-58392009000400001.

Elmer, L.A. 1942. Quinoa (Chenopodium quinoa). East Afr. Agric. J. 8: 21-23. doi: 10.1080/03670074.1942.11664212.

Espíndola, G. 1986. Respuestas fisiológicas, morfológicas y agronómicas de la quinua (Chenopodium quinoa Willd.) al déficit hídrico. Tesis M.Sc., Colegio de Postgraduados. Institución de Enseñanza e Investigación en Ciencias Agrícolas. Chapingo México. 101 p.

FAO. 2003. Issues in the global tobacco economy: Selected case studies. Food and Agriculture Organization of the United Nations, Rome.

FAO \& CIRAD. 2015. State of the Art Report of Quinoa in the World in 2013, by D. Bazile, D. Bertero \& C. Nieto, eds. Rome.

Fuentes, F., Bazile, D., Bhargava, A. \& Martinez, E.A. 2012. Implications of farmers' seed exchanges for on-farm conservation of quinoa, as revealed by its genetic diversity in Chile. Journal of Agricultural Science, 150 (6): pp. 702-716.

Fitter, A.H. \& Fitter, R.S.R. 2002. Rapid changes in flowering time in British plants. Science 296: 1689-1691.

Galwey, N.W., Leakey, C.L.A., Price, K.R. \& Fenwick, G.R. 1990. Chemical composition and nutritional characteristics of quinoa (Chenopodium quinoa Willd.). Food Sciences and Nutrition, 42F (4), 245-261.

Garcia, M., Raes, D. \& Jacobsen, S.E. 2003. Evapotranspiration analysis and irrigation requirements of quinoa (Chenopodium quinoa) in the Bolivian highlands. Agric. Water Manag. 60, 119-134. doi: 10.1016/S0378-3774(02)00162-2.

Gauch, H.G. 2006. Statistical analysis of yield trials by AMMI and GGE. Crop Sci. 46:1488-1500.

Geerts, S., Dirk Raes, D., Garcia, M., Vacher, J., Mamani, R., Mendoza, J., Huanca, R., Morales, B., Miranda, R., Cusicanqui, J. \& Taboada, C. 2008. Introducing deficit irrigation to stabilize yields of quinoa (Chenopodium quinoa Willd.). Europ. J. Agronomy 28 (2008) 427-436. 
Gonzalez, J.A., Konishi, Y., Bruno, M., Valoy, M. \& Prado, F. E. 2012. Interrelationships among seed yield, total protein and amino acid composition of ten quinoa (Chenopodium quinoa) cultivars from two different agroecological regions. J. Sci. Food Agric. 92, 1222-1229. doi: 10.1002/jsfa.4686.

Hirose, Y., Fujita, T., Ishii, T. \& Ueno, N. 2010. Antioxidative properties and flavonoid composition of Chenopodium quinoa seeds cultivated in Japan. Food Chemistry, 119 (4) (2010), pp. 1300-1306.

IA ASTD. 2009. Agriculture at a crossroads: Sub-Saharan Africa (SSA) report (Vol. V). International Assessment of Agricultural Knowledge, Science and Technology for Development. Washington, DC: Island Press.

Jacobsen, J.C.B., Gustafsson, F. \& Holstein-Rathlou, N.-H. 2003. A model of physical factors in the structural adaptation of microvascular networks in normotension and hypertension. Physiological Measurement, 24(4): 891-912. https://doi.org/10.1088/0967-3334/24/4/007

Jacobsen, S.E. 1997. Adaptation of quinua (Chenopodium quinua) to Northern European agriculture: studies on developmental pattern. Euphytica 96: 41-48.

Jacobsen, S.E. 2003. The Worldwide Potential for Quinoa (Chenopodium quinoa Willd.). Food Reviews International, 19 (1-2) (2003), pp. 167-177.

Jacobsen, S.E., Mujica, A. \& Jensen, A.C. 2003. The resistance of quinoa (Chenopodium quinoa Willd.) to adverse abiotic factors. Food Rev. Inte. 19:1-2.

Jacobsen, S.E., Montelos, C., Corcuera L.J., Bravo L.A., Christiansen, J.L. \& Mujica, A. 2007. Frost resistance mechanism in Quinoa (Chenopodium quinoa Willd.) European Journal of Agronomy $22,131-139$.

Kaesha, N. 2009. Flowering phenology: An activity to introduce human \& environmental effects on plant reproduction. The American Biology Teacher 71(5).

Kanyumbu, A.F. 2015. Grain yield and quality traits of quinoa (Chenopodium quinoa Willd) in response to fertilizer application. A project report submitted in partial fulfilment of the requirements for Bachelor of Science Degree in Agronomy, Faculty of Agriculture, Lilongwe University of Agriculture and Natural Resources (LUANAR), Bunda Campus, Lilongwe.

Kathabwalika, D.M., Chilembwe, E.H.C., Mwale, V.M., Kambewa, D. \& Njoloma, J.P. 2013. Plant growth and yield stability of orange-fleshed sweet potato (Ipomea batatas L.) genotypes in three agro-ecological zones of Malawi. Intl. Res. J. Agric. Sci. and Soil Sci., Vol. 3 (11): 383-392.

Khaemba, J. 2015. Production and utilization of quinoa (Chenopodium quinoa Willd.) outside its traditional growing areas: a case of Kenya. Chapter 6.32 in FAO \& CIRAD. State of the Art Report of Quinoa in the World in 2013, by D. Bazile, D. Bertero \& C. Nieto, eds. Pp. 534-548. Rome.

Kimenju, J.W., Kagundu, J.H., Nderitu, F., Mambala, G.K., Mutua \& Kariuki, G.M. 2008. Incorporation of green manure into bean cropping systems contribute to root-knot nematode suppression. Asian Journal of Plant Science, 7 (4): 404-408.

Kozioł, M.J. 1992. Chemical composition and nutritional evaluation of quinoa (Chenopodium quinoa Willd.). Journal of Food Composition and Analysis 5 (1) (1992), pp. 35-68.

Lin, C. S. \& Binns, M. R. 1988. A superiority measure of cultivar performance or cultivar x location data. Can. J. Plant Sci. 68: 193-198.

Lipenga, S. 2016. Response of quinoa (Chenopodium quinoa Willd) varieties on growth and grain yield to different plant spacing. A project report submitted in partial fulfilment of the requirements for Bachelor of Science Degree in Agronomy, Faculty of Agriculture, Lilongwe University of Agriculture and Natural Resources (LUANAR), Bunda Campus, Lilongwe. 
Mabedi, F. 2015. Plant growth and grain yield of quinoa (Chenopodium quinoa Willd) in response to time of planting under rainfed conditions. A project report submitted in partial fulfilment of the requirements for Bachelor of Science Degree in Agronomy, Faculty of Agriculture, Lilongwe University of Agriculture and Natural Resources (LUANAR), Bunda Campus, Lilongwe.

Maliro, M.F.A., Guwela, V.F., Nyaika, J. \& Murph, K.M. 2017. Preliminary Studies of the Performance of Quinoa (Chenopodium quinoa Willd.) Genotypes under Irrigated and Rainfed Conditions of Central Malawi. Front. Plant Sci. 8:227. doi: 10.3389/fpls.2017.002.

Maliro, M.F.A. \& Guwela, V. 2015. Quinoa breeding in Africa: History, Goals, and Progress. In K.M. Murphy and J.G. Matanguihan, eds. Quinoa: Improvement and Sustainable Production, WileyBlackwell. Hoboken, New Jersey, USA.

Moreno, C., Seal, C.E \& Papenbrock, J. 2018. Seed priming improves germination in saline conditions for Chenopodium quinoa and Amaranthus caudatus.J. Agro Crop Sci. 204:40-48. https://doi.org/10.1111/ jac.12242.

Mujica, A., Cahahuay, A. \& Saravia, R. 2004. Agronomía de la quinua. In A. Mujica, S. Jacobsen, J. Izquierdo y JP. Marathee. Quinua: Ancestral cultivo andino, alimento del presente y futuro. FAO. UNA. CIP. Santiago, Chile. pp 26-59.

Mukankusi, C., Amongi, W., Berhanu, F., Wanderi, S., Rono, B.K., Okee, J., Okiro, A.O., Mwaba, C., Kooma, E. \& Abang, M. 2016. Adaptability of quinoa (Chenopodium quinoa Willd) in Eastern and Southern Africa: Potential implications for food security and climate change adaptation. Proceedings of the International Quinoa Conference, 2-9 December, 2016. http://www.quinoaconference.com/ sites/default/files/Mukankusi-Uganda.pdf

Nachipo, C. 2017. Effect of storage period on viability and germinability of quinoa (Chenopodium quinoa Willd) seed. A project report submitted in partial fulfilment of the requirements for Bachelor of Science Degree in Agronomy, Faculty of Agriculture, Lilongwe University of Agriculture and Natural Resources (LUANAR), Bunda Campus, Lilongwe.

Ojany, F.F. \& Ogendo, R.B. 1988. Kenya: A Study in Physical and Human Geography. Longman, Kenya.

Olesen, J. E., Børgensen, C.D., Elsgaard, L., Palosuo, T., Rötter, R., Skjelvåg, A.O., Peltonen-Sainio, P., Börjesson, T., Trnka, M., Ewert, F., Siebert, S., Brisson, N., Eitzinger, J., van der Fels-Klerx, H. J. \& van Asselt, E. 2012. Changes in time of sowing, flowering and maturity of cereals in Europe under climate change. Food Additives and Contaminants: Part A 29(10), 1 527-1 542. doi:10.1080/19 440049.2012.712060.

Orsini, F., Accorsi, M., Gianquinto, G., Dinelli, G., Antognoni, F. \& Ruiz Carrasco, K.B. 2011. Beyond the ionic and osmotic response to salinity in Chenopodium quinoa: functional elements of successful halophytism. Funct. Plant. Biol. 38(10): 818-831. doi:10.1071/FP11088.

Oyoo, M.E., Githiri, S.M. \& Ayiecho, P.O. 2010. Performance of some quinoa (Chenopodium quinoa Willd.) genotypes in Kenya. S. Afr. J. Plant E Soil 27:2, p. 187-190.

Pearsall, D.M. 1992. The origins of plant cultivation in South America. In C. Wesley Cowan \& P.J. Watson, eds. The origins of agriculture: an international perspective. Smithsonian Institution Press, Washington DC.

Pulvento, C., Riccardi, M., Lavini, A., Iafelice, G., Marconi, E. \& d'Andria, R. 2012. Yield and quality characteristics of quinoa grown in open field under different saline and non-saline irrigation regimes. J. Agron. Crop. Sci. 198(4): 254-263. doi:10.1111/j. 1439-037X.2012.00509.x.

Pulvento, C., Riccardi, M., Lavini, A., D’Andria, R., Iafelice, G. \& Marconi, E. 2010. Field trial evaluation of two Chenopodium quinoa genotypes grown under rain-fed conditions in a typical 
Mediterranean environment in south Italy. J. Agron. Crop Sci. 196, pp. 407-411. doi: 10.1111/j.1439037X.2010.00431.x.

Repo-Carrasco-Valencia, R.A.-M. \& Serna, L.A. 2011. Quinoa (Chenopodium quinoa, Willd.) as a source of dietary fiber and other functional components. Ciência E Tecnologia de Alimentos 31(1): $225-230$.

Repo-Carrasco, R., Espinoza, C. \& Jacobsen, S.E. 2003. Nutritional value and use of the Andean crops quinoa (Chenopodium quinoa) and kan iwa (Chenopodium pallidicaule). Food Rev. Int. 19(1-2): 179-189. doi:10.1081/FRI-120018884.

Rillo, A.D. \& Nugroho, S.A. 2016. Promoting Agricultural Value Chain Integration in Central Asia and the Caucasus. Policy brief No. 2016-4 (November), Asian Development Bank Institute (ADBI), Tokyo, ISSN 2411-6734. Accessed in July 2018 from https:/www.adb.org/sites/default/files/ publication/214121/adbi-pb2016-4.pdf

Risi, J. 1997. La quinua: actualidad y perspectivas. In Taller sobre desarrollo sostenible de la quinua. Instituto Interamericano de Cooperación para la Agricultura - IICA, Camara de Exportadores. La Paz, Bolivia.

Rojas, W., Pinto, M., Alanoca, C., Gomez Pando, L., Leon-Lobos, P. \& Alercia, A. 2015. Quinoa genetic resources and ex situ conservation. In D. Bazile, H. D. Bertero \& C. Nieto, eds. State of the Art Report on Quinoa Around the World in 2013. Roma: FAO \& CIRAD, pp. 56-82.

Ruiz, K.B., Biondi, S., Oses, R., Acuña-Rodríguez, I.S., Antognoni, F., Martinez-Mosqueira, E. A., Coulibaly, A., Canahua-Murillo, A., Pinto, M., Zurita, A., Bazile, D., Jacobsen, S.E. \& Molina Montenegro, M. 2014. Quinoa biodiversity and sustainability for food security under climate change. A review. Agronomy for Sustainable Development, 34 (2): p. 349-359. http://dx.doi.org/10.1007/ s13593-013-0195-0

Ruiz-Carrasco, K.B., Antognoni, F., Coulibaly, A.K., Lizardi, S., Covarrubias, A., Martínez, E.A., Molina-Montenegro, M.A., Biondi, S. \& Zurita-Silva, A. 2011. Variation in salinity tolerance of four lowland genotypes of quinoa (Chenopodium quinoa Willd.) as assessed by growth, physiological traits, and sodium transporter gene expression. Plant Physiology and Biochemistry 49: 1333-1341.

Souza, F.F.J, de Souza, J.E.A, Souza, N.O.S, Spehar, C.R. \& de Jesus, T.F. 2017. Standardizing germination tests for quinoa seeds. African Journal of Agricultural Research 12 (3): 155-160. DOI: 10.5897/AJAR2016.11820.

Strenske, A., de Vasconcelos, E.S., Egewarth, V.A., Herzog, N.F.M. \& de Matos Malavasi, M. 2017. Responses of quinoa (Chenopodium quinoa Willd.) seeds stored under different germination temperatures. Acta Scientiarum Agronomy 39: 83-88, ISSN on-line: 1807-8621. Doi: 10.4025/ actasciagron.v39i1.30989.

Williams, J.T. ed. 1995. Cereals and Pseudocereals. 350 pp. London, Chapman \& Hall. This book introduces some important pseudocereals (e.g. buckwheat, grain amaranth, quinoa) and their history, use, taxonomy, ecology, agronomy, biochemistry, etc.

Wright, K.H., Pike, O.A., Fairbanks, D.J. \& Huber, C.S. 2002. Composition of Atriplexhortensis, sweet and bitter Chenopodium quinoa seeds. Journal of Food Science 67 (4) (2002), pp. 1383-1385.

Yazar, A., Incekaya, C., Sezen, M.S. \& Tekin, S. 2015. Quinoa Experimentation and Production in Turkey. Chapter 6.1.4. in FAO \& CIRAD. In D. Bazile, H. D. Bertero \& C. Nieto, eds. State of the Art Report on Quinoa Around the World in 2013. Roma: FAO \& CIRAD, pp. 466-477.

Zevallos, V.F. 2014. Gastrointestinal effects of eating quinoa (Chenopodium quinoa Willd.) in celiac patients. American Journal of Gastroenterology 109 (2): 270-8. 
Notes 

For more information, please contact:

FAO Subregional Office for Southern Africa

FAO-SFS@fao.org

Food and Agriculture Organization of the United Nations

Harare, Zimbabwe

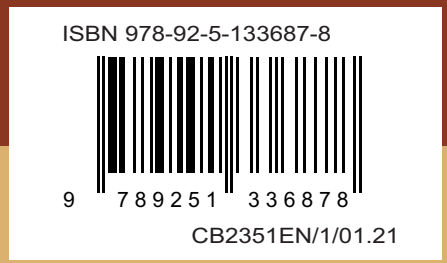

